\title{
Joies Botàniques \\ de la Ribera i voltants
}

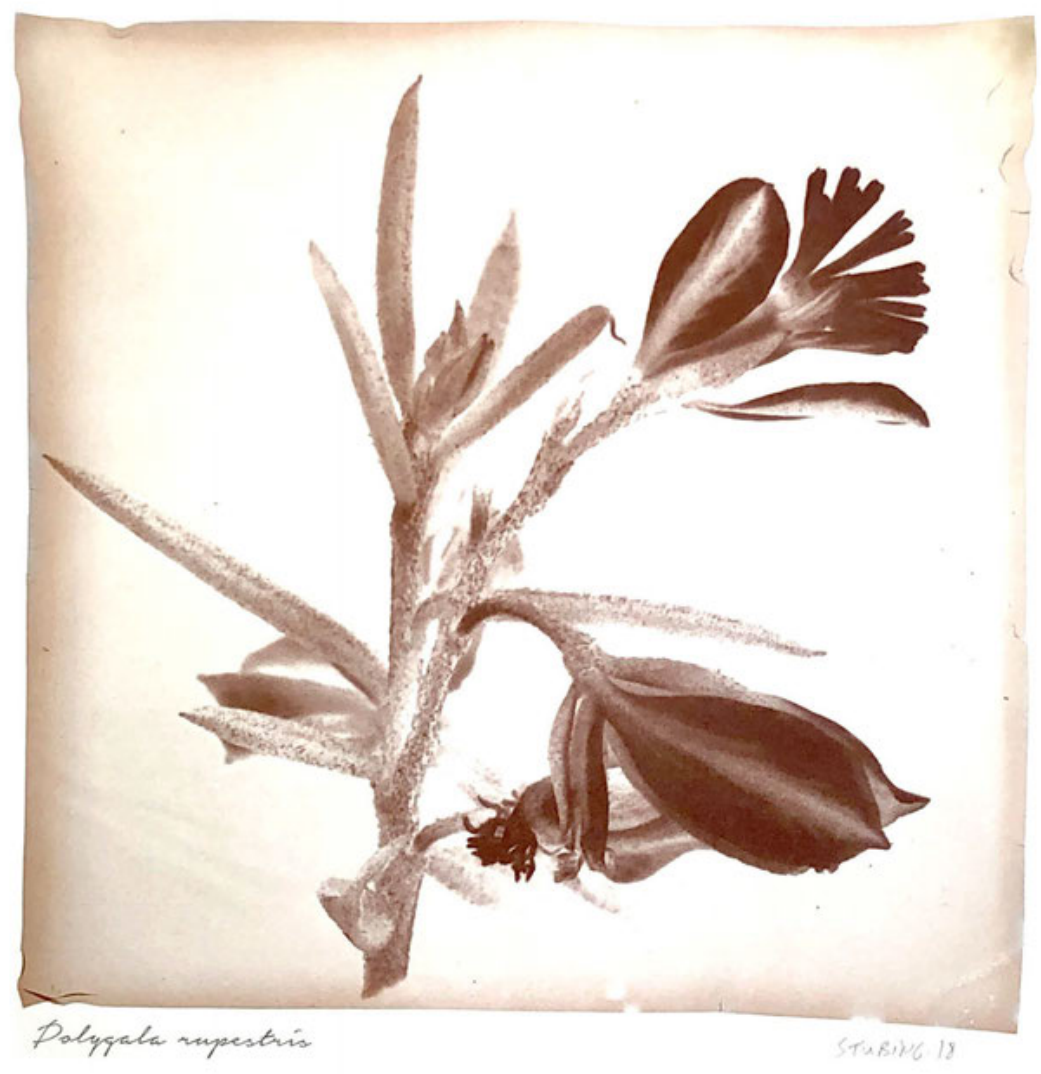

Gerardo Stübing 


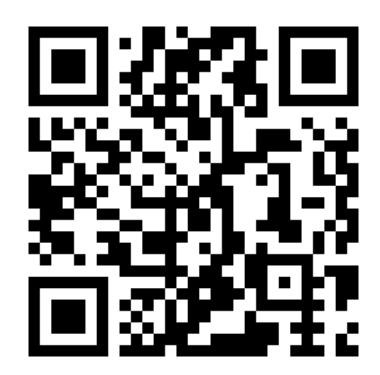

www.gerardostubing.com/

FITXA TĖCNICA

Comissaris: Aureli Domenech / Tono Herrero

Textos: Aureli Domènech / Tono Herrero / Juan Bautista Peris / Emilio Laguna / Gerardo Stübing

Fotografies: Gerardo Stübing / Emilio Laguna

(C) Gerardo Stübing

ISBN: 978-84-9133-386-9

DOI: http://dx.doi.org/10.7203/PUV-OA-386-9

\section{(c) (1) $\Theta \Theta$}

Aquesta obra està sota una Llicència Creative Commons Reconeixement-NoComercial-SenseObraDerivada 4.0 Internacional.

\section{AGRAIIMENTS}

Moltes han sigut les institucions i persones que han fet possible, gràcies a la seua implicació desinteressada, este projecte: Txema Peláez Palazón, Presidente de la Mancomunidad de La Ribera; Jorge Hermosilla Pla, Vicerrector de Participació i Projecció Territoriial de la Universitat de Valencia; David Pons Garcia, Alcalde del Ajuntament de Su-macàrcer; Aureli Domènech Bou i Tono Herrero Giménez, Comissaris de l'exposició; Eulalia Adelantado Mateu i Jose Pedro Martinez Garcia Directors del meu treball de tesi doctoral en producció artística que inclou este treball; Emilio Laguna Lumbreras i Juan Bautista Peris botánics i amics. 


\section{Joies Botàniques de la Ribera i voltants}

Gerardo Stübing

"Les espècies estan determinades per la bellesa"

Charles Darwin (The Descent of Man, 1871) 


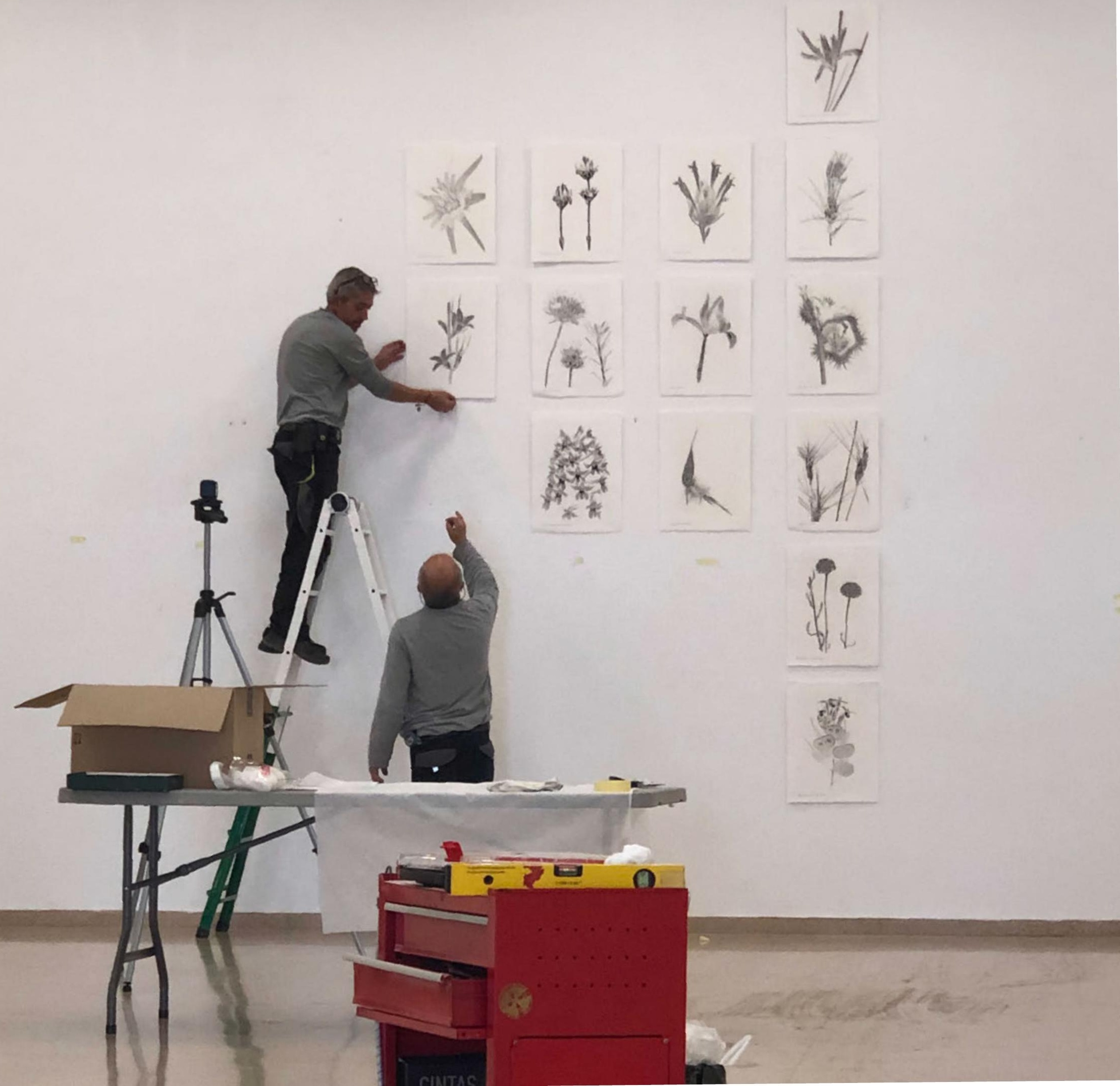




\section{INDEX}

\section{Presentacions}

Joies Botàniques de la Ribera i voltants 6

Natura naturata $\quad 12$

Nota interna.com 14

Flora de la Ribera: Rellevància i valor per a la conservació 24

\section{Obres}

Cianotípies 28

Argirotipies 62

Platinotpies 72

Impressions lumíniques $\quad 82$

Mayo 2050 (políptic) 94

Biografía / Statement 102 


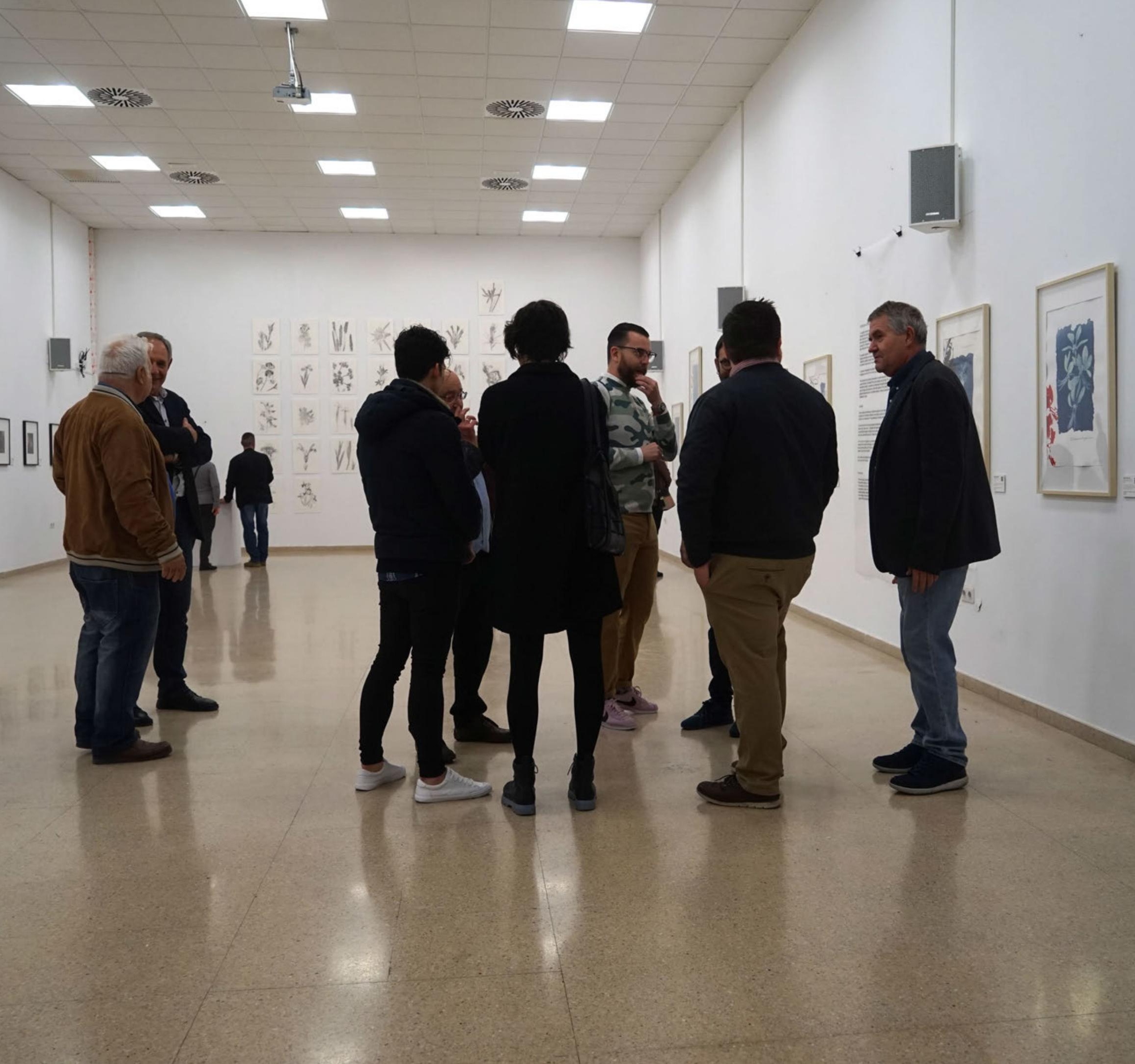




\section{Joies Botàniques de la Ribera i voltants}

Són molts els trets que caracteritzen la Ribera. El fet de pertànyer a un mateix territori fa que tinguem uns nexes d'unió i unes característiques comunes que, a poc a poc, han anat conformant la nostra societat, el nostre caràcter i les nostra identitat com a comarca. Però, paradògicament, un dels trets que més ens caracteritzen és la nostra diversitat.

La Ribera és una comarca extensa. Som 47 municipis, prop de 1.300 km2 i més de 300.000 habitants, i aquestes xifres ja ens mostren una diversitat que sempre ens ha enriquit culturalment. Som riberencs, pertanyem a la mateixa comarca, però dins del nostre territori trobem diversos paisatges, diversos parlars, diversos cultius, trobem pobles grans, mitjans i menuts, pobles amb platja i pobles amb muntanya... i tots formem part de la Ribera.

La Mancomunitat de la Ribera Alta, entitat que agrupa els 35 municipis de la part interior de la Ribera, sempre ha apostat per la promoció de la cultura i divulgació d'estudis i treballs amb caràcter comarcal. Des del seus inicis, la Mancomunitat ha publicat diversos treballs de diferents temàtiques però sempre amb el vincle comú del nostre territori. Des de la Mancomunitat, s'han realitzat treballs sobre temes com l'economia, el patrimoni arquitectònic, el patrimoni rural, els ponts del Xúquer, personatges de la Ribera o el treball de l'historiador Tomàs Peris Albentosa sobre la història de la nostra comarca, publicat en sis volums. 
Ara, des de la Mancomunitat, hem tingut l'oportunitat de patrocinar, conjuntament amb el Vicerectorat de Projecció Territorial i Societat de la Universitat de València i la Conselleria d'Agricultura, Desenvolupament Rural, Emergència Climàtica i Transició Ecològica, l'exposició Joies Botàniques de la Ribera, on l'artista Gerardo Stübing presenta tota una sèrie de treballs realitzats amb diverses tècniques artístiques que tenen com a element comú la utilització de les plantes autòctones de la comarca amb la finalitat de sorprendre l'espectador.

L'exposició consta de diverses obres úniques inspirades en la flora autòctona del territori realitzades sobre diversos suports i amb diverses tècniques. Es tracta d'una exposició que apropa al públic en general la riquesa botànica que tenim en el nostre territori i, sens dubte, és una forma de conèixer el nostre patrimoni, de ser coneixedors de tota la riquesa botànica que ens envolta i, en definitiva, d'aproparnos a la nostra comarca.

Però si certament la nostra comarca és diversa, també hem de dir que és canviant, i el nostre patrimoni botànic no és aliè a aquests canvis. El treball que ens presenta Gerardo Stübing ens mostra el nostre patrimoni actual, però ens deixa una pregunta: iserà el mateix patrimoni d'ací 20, 40 o 50 anys? ¿Com canviaran els nostres paisatges en les pròximes dècades? ¿Com ens afectaran factors com el canvi 


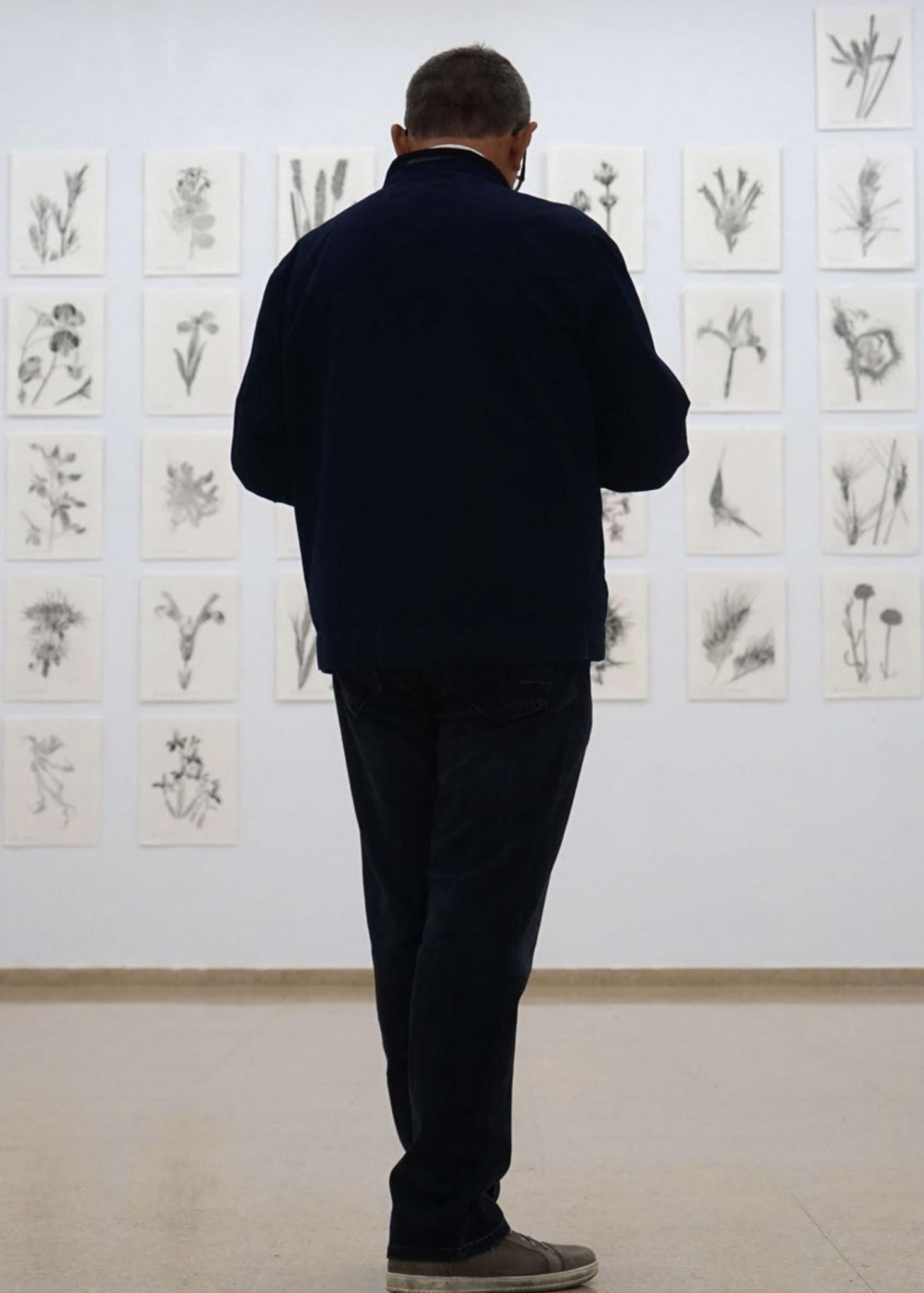




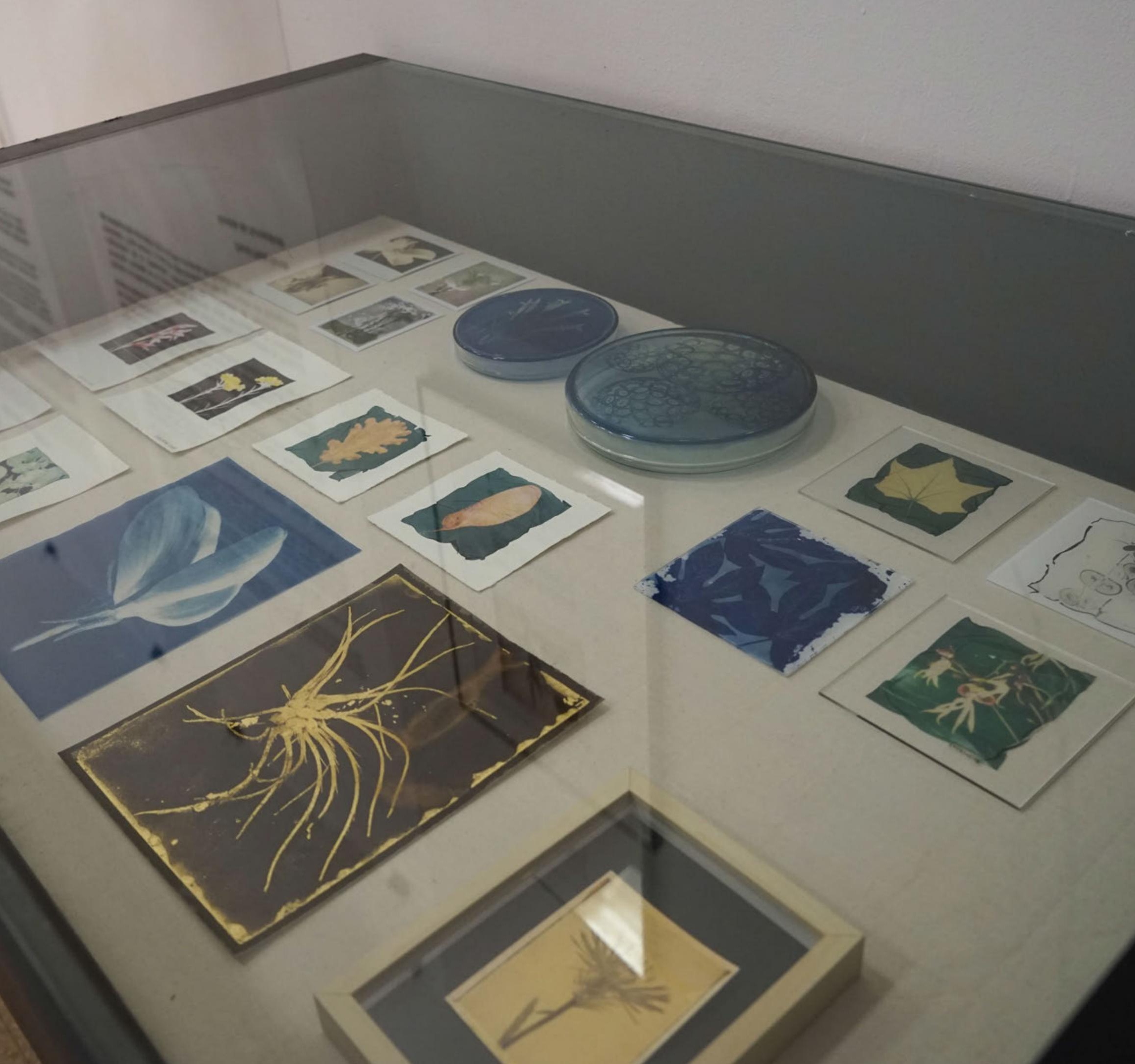


climàtic? Aquesta exposició ens fa reflexionar sobre aquests aspectes i vol conscienciar-nos (i ben cert que ho aconsegueix) del perill que corre el nostre patrimoni natural i que cal cuidar-lo i preservar-lo.

Des de la Mancomunitat de la Ribera Alta, com a entitat preocupada per la nostra cultura i el nostre territori, estem convençuts que l' exposició Joies Botàniques de la Ribera de Gerardo Stübing és una oportunitat immillorable per a promoure el nostre patrimoni natural, la nostra geografia i, en definitiva, la nostra cultura, a més de ser una eina per a la vertebració del nostre territori.

Txema Peláez Palazón

Mancomunitat de la Ribera Alta 


\section{Natura naturata}

El Vicerectorat de Projecció Territorial i Societat de la Universitat de València fa anys que promou activitats encaminades a integrar la institució i els seus recursos científics i culturals en la societat, i a desplegar aquestes iniciatives en l'àmbit territorial valencià.

Entre les nombroses accions que s'han anat desenvolupant, sens dubte aquelles relacionades amb el coneixement i la conservació del nostre entorn han representat una de les principals inquietuds d'aquesta institució acadèmica.

L'any 2015, la Universitat de València, a través d'aquest Vicerectorat, va patrocinar i va editar el catàleg de l'exposició itinerant Cavanilles/Stübing, un camí, dues mirades, que va recórrer diverses localitats valencianes. S'hi destacava el valor de la nostra flora i la figura de l'insigne botànic valencià Antoni Josep Cavanilles i Palop. En aquella ocasió Gerardo Stübing, artista, botànic i professor d'aquesta universitat, va ser l'encarregat de realitzar-lo.

En aquesta nova ocasió, i amb el patrocini de la Mancomunitat de la Ribera Alta i de la Universitat de València, l'artista, el professor Stübing, ens presenta uns nous exposició i catàleg, l'objectiu del qual és sensibilitzar la societat del valor intrínsec de les creacions de la natura, la Natura naturata de Spinoza, amb la denúncia de la pèrdua de biodiversitat com 
una de les conseqüències del canvi climàtic.

En aquest projecte l'artista recorre a una hibridació entre l'exercici pictòric convencional i la fotografia experimental, integrant alquímicament tècniques dels segles XIX, XX i XXI per oferir-nos unes creacions artístiques poc convencionals i noves.

El treball presentat constitueix una mostra més de l'entusiasme i el compromís que el professor Stübing mostra en els seus projectes artístics. D'alguna manera, les missions que apuntava Ortega y Gasset relacionades amb la investigació, la formació i la transferència de coneixement fan la seua eclosió en aquesta magnífica mostra.

Jorge Hermosilla Pla

Vicerector de Projecció Territorial i Societat

Universitat de València 


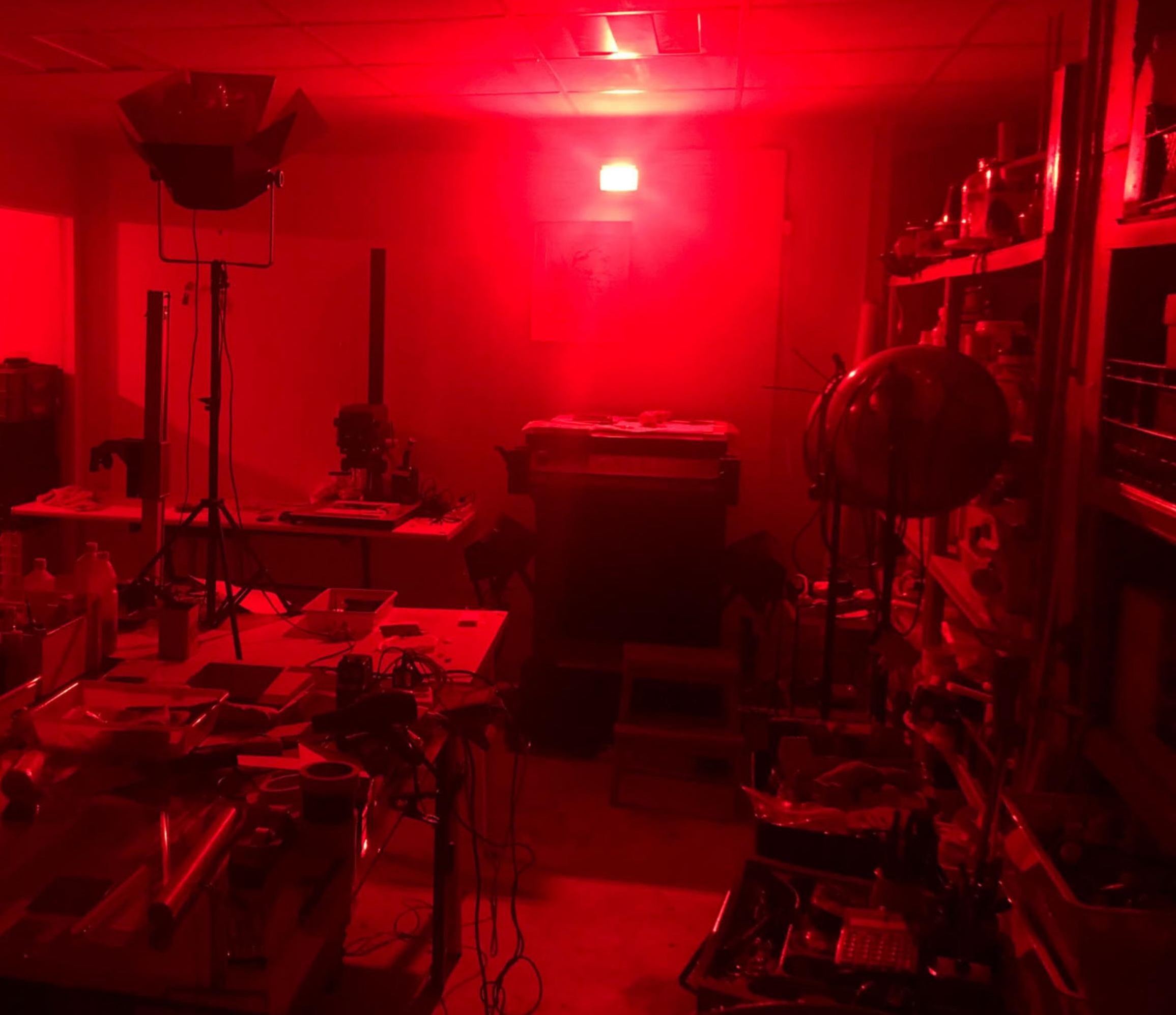




\section{Nota interna.com}

Com a part mateixa d'una naturalesa tangible, la botànica té una llarga tradició com a model i inspiració del quefer artístic i, des d'una vocació científica (salvant les distàncies del que cada època entén per ciència), la cultura visual unida a la botànica ha generat un imaginari perfectament reconeixible.

Queda com a paradigma d'aquesta història d'estretes relacions l'existència d'una activitat durant segles perfectament identificada i amb una vocació a mig camí entre l'art, la ciència i la tècnica: la figura de l'il|lustrador botànic. Una professió cabdal en el desenvolupament editorial d'herbaris i farmacopees que arriba a la seua màxima expressió en el segle XVIII, a l'ombra del naixement dels sistemes de nomenclatura i als avenços de les tècniques calcogràfiques d'impressió, que permetien gaudir de la subtilesa visual de tècniques com l'aquarel·la. Un treball precís, convertit en mitjà auxiliar ineludible per a l'avanç científic.

Hui, des d'una perspectiva de simulació de tècniques antigues i de reproducció artesanal, el "botanical art" és una activitat feliçment recuperada com una forma d'art de vocació decorativa. I en definitiva, se succeeixen en el nostre univers visual les il/ustracions de vocació taxonòmica, analítica o de pura representació morfològiques de l'àmbit de la botànica. Tradició que en una època de la humanitat ja lliurada a l'observació científica però sense mitjans per a la represen- 
tació fotogràfica converteix la relació entre art i botànica en un ampli llegat de tècniques i paradigmes.

Gerardo Stübing també pinta plantes. Però, com en tota dialèctica en l'art contemporani, sap que la fotografia ja realitza àmpliament la seua funció i la seua vocació no és formal ni descriptiva, encara que siga rigorosa, sinó purament estètica. Així que en tots els escrits en els que seguim amb interès la trajectòria de Gerardo sempre posem l'accent en el que considerem la definició bàsica de la seua arquitectura conceptual com a artista. Una definició que no per coneguda és menys certa. Gerardo Stübing com una mena de demiürg de dualitat científic-artística, i en la seua obra com un diàleg, més o menys racional o més o menys intuïtiu, entre aquestes dues naturaleses.

És sobre aquesta base estructural que conforma sobre la qual Gerardo Stübing ha creat un corpus artístic ple de lògica i coherència procedimental. L'interessant de visitar l'obra de Gerardo cada vegada és tractar d'analitzar, en una època en la qual per sort els algoritmes encara no han arribat a ser determinants en l'anàlisi de les Arts Visuals, com i quina faceta de Gerardo interactua amb l'obra. Com oscilla aquest moviment pendular que transita per la ciència i per l'art.

No es deixen enganyar. Ni tan sols per nosaltres. Explicar la tècnica, entendre el procés que desenvolupa el artista pot funcionar com una ajuda interessant o com una dada a ma- 


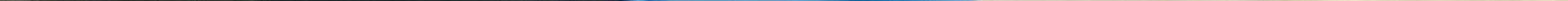




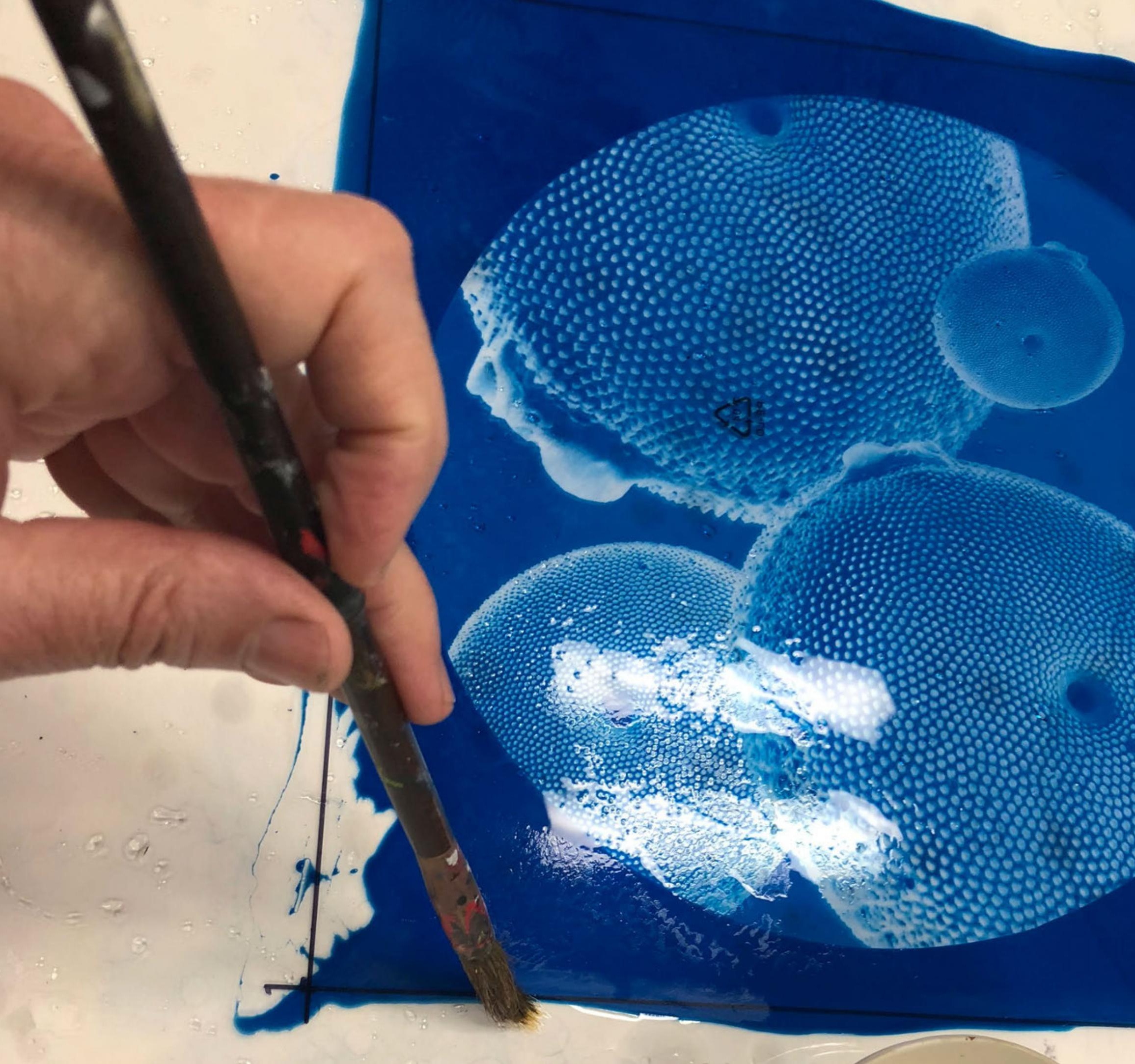


nera de curiositat cultural, però des de l'àmbit d'un espectador neutral dóna el mateix. L'obra de Gerardo es gaudeix en el seu conjunt com un tot: la conseqüència d'una interacció experimental sobre la matèria a parir del profund coneixement de la ciència.

Immersos com estem en una contemporaneitat de impostures, I'honestedat procedimental de Gerardo està fora de tot dubte. Per a aquesta sèrie de treballs trau la part més alquimística de l'artista i més experimental de manera que farà de la manipulació de les pròpies tècniques un relat pictòric.

Una d'aquestes tècniques destacables és la fotografi, que en aquest cas Gerardo no la utilitza amb el sentit científic que semblaria obligat. Com vam dir en una altra ocasió, Gerardo, en un univers visual concomitant amb imaginari perfectament reconeixible renuncia al paper de la fotografia com la certesa extrema. En aquest cas, la mateixa tècnica, filla de la certesa científica, esdevé en un mecanisme d'experimentació formal. Citem el nostre propi text realitzat per a la primera exposició de Gerardo sobre la qual vam tenir ocasió d'escriure.

En determinat punt, per Stübing el científic, "la certesa" (que ell anomena la impaciència) és percebuda com un inconvenient i des de la fotografia s'acaba per trencar el vidre per passar la forma pictòrica. Partint del seu camp, l'observació de la natura, les certeses científiques muten en l'abstracció 
d'un paisatge vist en llunyania, la textura d'una mirada fortament pròxima a l'objecte, l'obra com a objecte mateix. I el camp semiòtic s'expandeix de manera exponencial, perquè el científic deixa pas al pintor i flueix un univers visual que multiplica les conseqüències de l'observació botànica.

Junt a tècniques plenament contemporànies, Gerardo Stubing, també experimenta amb tècniques clàssiques a l'objecte de violentar-les per obtenir un resultat visualment poderós, propi i, per què no, nou. Gerardo utilitza i manipula negatius analògics convencionals i negatius de contacte que traspassa al suport mitjançant procediments tradicionals com les cianotípies, de nou una tècnica clàssica que del científic, va passar a l'artístic.

Per al lector poc avesat explicar que les cianotípies tracten d'un procés fotosensible (utilització de l'alteració que produeix la llum en els suports com la fotografia) que dóna com a resultat una imatge d'un blau prússia intens impresa en negatiu. Són molt representatius d'aquesta tècnica la utilització que es feia d'ella per als plànols arquitectònics tot i que cal destacar que va ser precisament en el camp de la il.lustració botànica, a través d'Anna Atkins, la que va posar la tècnica del cianotipus en pràctica.

Totes aquestes interaccions tècniques culminen en la transposició sobre un suport, generalment el paper, on les factors en joc fan gairebé impossible portar un control estricte 


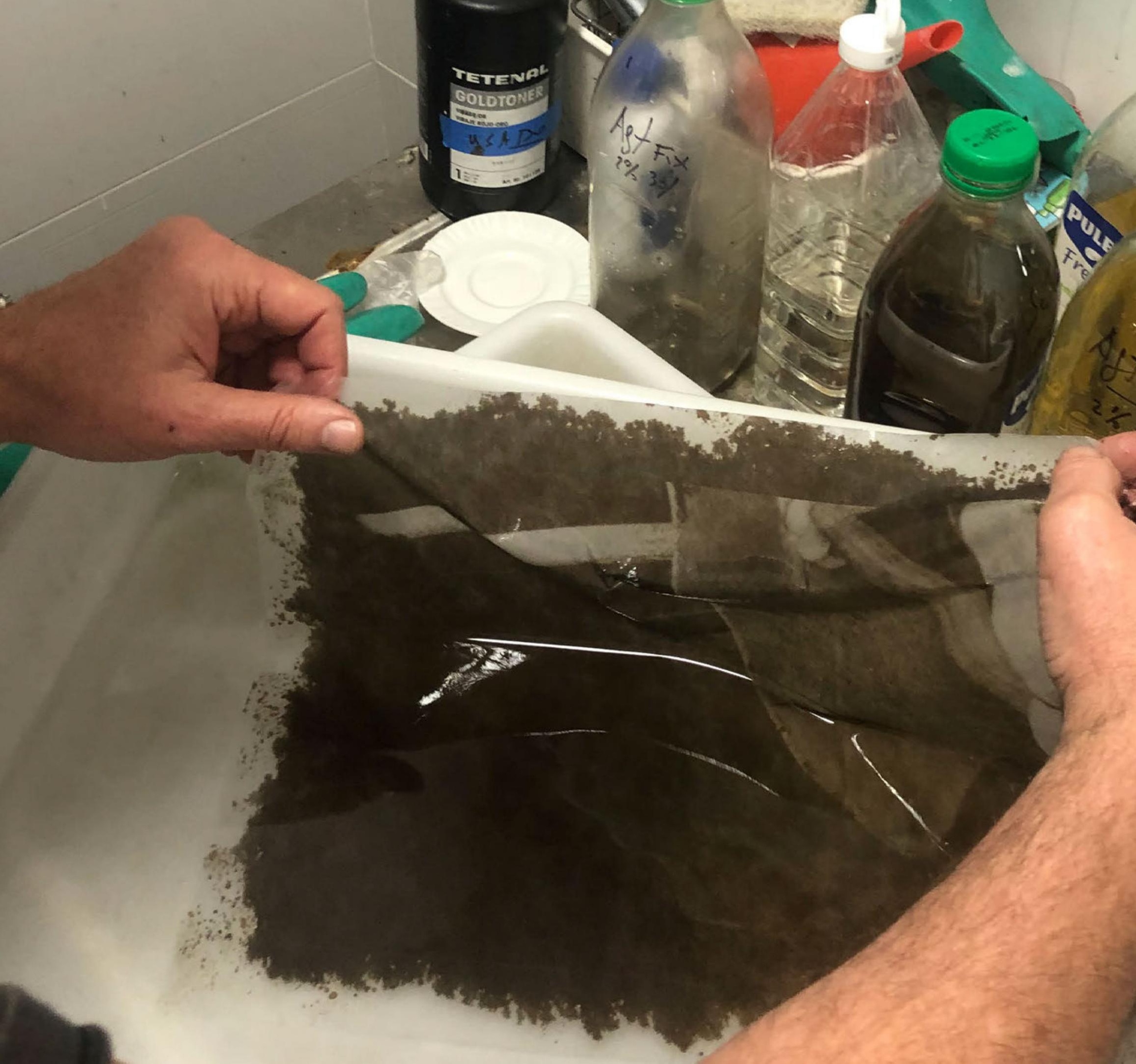




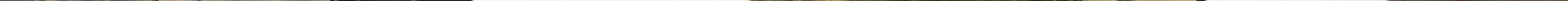


sobre la forma i el resultat final. Un tipus d'invitació a que l'atzar siga partícip del resultat de la pintura, i que en el seu indeterminisme, fa de cada obra un artefacte únic i irrepetible. Una obra on les tècniques d'índole fotogràfica s'hibriden amb la pintura, el dibuix, a través de l'ús de pintures i tintes aplicades amb pinzell; i el gravat, mitjançant la utilització del tòrcul i a través d'una sèrie complexa d'intervencions.

En definitiva el Gerardo científic, que opta per un criteri d'oportunitat en cenyir el seu univers temàtic a la riquesa botànica de la Ribera, es troba en aquesta ocasió amb el Gerardo tècnicament més obert a la indeterminació dels últims temps. Tot això a través de l'herència de tècniques i formes clàssiques traspassades a la necessitat del llenguatge i la presència contemporània, en la qual l'artista opta, també, per fer-se present com a subjecte polític.

L'obra "Maig 2050" és el vaixell insígnia de l'exposició i la proposta. Un missatge de denúncia social centrat en la pèrdua de biodiversitat lligada fonamentalment a les activitats humanes i les seues conseqüències com el canvi climàtic concebut com un happening visitant en la qual es posa de manifest l'extinció d'espècies com a conseqüència de la intervenció dels participants.

Aureli Domènech / Tono Herrero Comissaris de l'exposició 


\section{Flora de la Ribera: Rellevància i valor per a la con- servació}

La Ribera, territori natural que abasta les comarques administratives de la Ribera Alta i La Ribera Baixa, és el territori pel qual discorre el tram final del riu Xúquer i les planes i muntanyes que l'acompanyen. Els seus terrenys cultivats es compten entre els més fèrtils de la geografia valenciana, però encara que ara constitueixen terra ferma, no fa molts milers d'anys van ser part del mar Mediterrani, i moltes de les actuals muntanyes eren illes emergides, on l'evolució biològica va permetre la selecció de nombroses noves espècies vegetals silvestres, que ara per ara es consideren joies de la botànica valenciana. Destaquen per a aqueix grup de plantes els endemismes valencians, és a dir, aquelles plantes exclusives que no existeixen en altres zones del planeta, excepte a la Comunitat Valenciana. I si moltes de les seues espècies mereixen eixa qualificació, alguns dels llocs que els alberguen, des dels ullals del tram meridional de L'Albufera fins als pics més elevats de les Serres de Corbera, la Murta i les Agulles, o la Serra del Cavalló, constitueixen autèntics santuaris naturals de visita obligada per a botànics i amants de la naturalesa.

La Ribera constitueix el nucli on es van generar espècies que tenen ací la seua principal concentració a nivell mundial, com ocorre amb el guardallop negre (Verbascum fontqueri). Fins i tot una espècie, l'herba d'ulleres anomenada Biscutella 
riberensis, deu el seu nom a aquesta comarca natural. Moltes altres espècies són compartides amb terrenys pròxims d'altres comarques, com el rabet de gat rosat (Sideritis regimontana subsp. edetana), la tramussera valenciana (Lupinus mariae-josephae) o les ensopegueres de Dufour (Limonium dufourii) o de Mansanet (Limonium mansanetianum). Fins i tot algunes plantes més freqüents i àmpliament conegudes o utilitzades a nivell popular, com la pebrella (Thymus pipereIla), són endemismes llevantins que troben en La Ribera una part substancial de les seues poblacions i efectius a nivell mundial.

La posició geogràfica de la Ribera també ha privilegiat el seu paper de territori d'acolliment de dotzenes d'espècies singulars de distribució més àmplia, incloent plantes que només es coneixen ací per a tot el territori valencià, com ocorre amb la malva arborescent de l'espècie Lavatera o/bia a Llaurí. Altres joies d'aquest grup el constitueixen plantes aquàtiques rares i de distribució molt limitada, com el nenúfar silvestre (Nymphaea alba), que viu en alguns dels ullals de L'Albufera. La diversitat del paisatge ha permés que molts llocs actuen com a refugi d'algunes de les espècies valencianes més amenaçades, com ocorre amb l'orquídia Anacamptis papilionacea subsp. grandiflora a Sumacàrcer, la llengua de cérvol sagitada (Phyllitis sagittata) a Cullera, o la falaguera aquàtica (Thelypteris palustris) en el riu Verd a Benimodo. 
La potencialitat de la Ribera per a albergar espècies botàniques singulars és tan notable, que fins i tot llocs de creació artificial recent, com la coneguda Llacuna del Samaruc d'Algemesí, han permés establir en pocs anys poblacions estables de moltes de les espècies valencianes amb més projecció internacional, com la trencadalla o malva de L'Albufera (Kosteletzkya pentacarpos), mereixent la protecció del lloc com a Microreserva de Flora. La Ribera també alberga algunes de les escasses representacions valencianes de tipus de vegetació singulars, com les restes de les primitives bosquines de llorer silvestre (Laurus nobilis), presents en llocs tan singulars com el Barranc de la Murta a Alzira, o els Cingles a Llaurí.

En concordança amb una riquesa botànica tan notable, La Ribera posseeix un ampli elenc d'espais naturals protegits. A més d'abastar un ampli sector meridional del Parc Natural de l'Albufera, existeixen diversos Paratges Naturals Muncipals proposats i gestionats pels ajuntaments, com ocorre amb La Murta i la Casella a Alzira, Matamón a Catadau, la Muntanya de Llaurí, L'Hort de Soriano-Font de la Parra a Carcaixent, Les Fontanelles a Corbera, o Els Cerros, El Tello i La Colaita a Llombai. En el mateix sentit, són abundants les ortacions d'este territori a la xarxa valenciana de Microreserves de Flora, de la que en 2019 es complixen els 25 anys de la creació de la seua singular figura jurídica. 
Esta notable singularitat botànica constitueix també un element d'alt valor cultural, degut a l'estreta relació entre la diversitat vegetal i els usos tradicionals de les plantes, els noms populars de les quals figuren a més en molts dels topònims dels enclavaments més coneguts dels seus termes municipals. Un exemple evident és el del barranc i serra de la Murta, que sens dubte és a més el santuari botànic de més projecció de tot el territori comarcal.

La flora silvestre és un patrimoni natural que roman encara en un segon pla, i sens dubte mereixeria ser posat en valor, donant una fama molt superior a la Ribera. Per a això, es proposa donar a conéixer a la població local i visitant una selecció d'espècies vegetals notables o destacades, combinant les seues imatges amb textos explicatius. Sabut és que no es pot conservar el que no es coneix, i el coneixement d'aquesta riquesa botànica pot i deu facilitar-se, com a element fonamental per a garantir la seua permanència per a les pròximes generacions.

Emilio Laguna Lumbreras* / Juan Bautista Peris Gisbert ** Gerardo Stübing Martinez **

*Cap de Secció de Protecció dels Recursos Naturals

Conselleria d'Agricultura, Desenvolupament Rural, Transició Ecològica i Emergència Climática de la Generalitat Valenciana.

** Professors del Departament de Botànica i Geologia de la Universitat de València. 


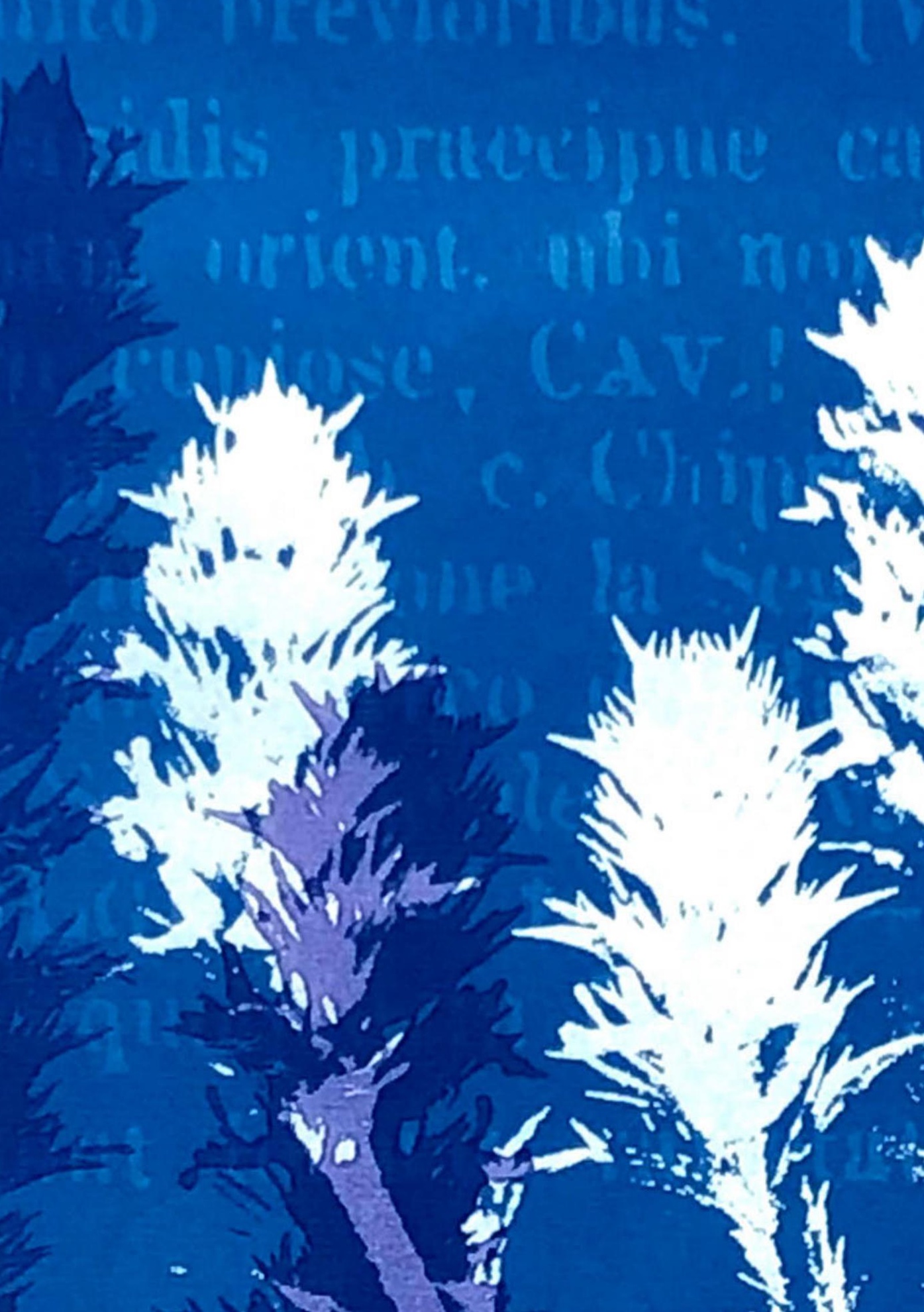




\section{CIANOTÍPIES}

Tècnica antiga, inventada per l'astrònom anglès Sir John Herschel en 1842, i que va ser utilitzada per la botànica britànica Anna Atkins a partir de 1843 per publicar una sèrie d'obres on es representen "fotogràficament" diverses plantes, falgueres $i$ algues.

El procés parteix d'una solució aquosa fotosensible que s'aplica sobre un suport (paper, teixits, fusta, vidre, etc.). Després de l'assecatge en foscor, es disposen sobre aquest suport objectes opacs a la llum (en el nostre cas negatius) i s'exposa el conjunt a l'acció dels raigs ultraviolats del sol o d'altres fonts.

A les zones no opaques es produeix una reacció química que fa que adquirisquen, després d'un revelat amb aigua, un color blau, pel fet que en elles queda fixat un pigment blau denominat Blau de Prússia, amb més o menys densitat depenent de l'opacitat que afecte a la zona en qüestió. Així s'obté una imatge monocroma amb una àmplia gamma tonal de blaus i blancs que rep el nom de cianotip. 


\section{Card verd}

Cardo verde

Carduus nigrescens Vill. subsp. nigrescens

Asteràcies

\section{Etimologia}

"Carduus": derivat possiblement d'un dialecte provincial del llatí, probablement nord-africà, de cardius, -i, (=card), que en un sentit molt ample fa referència a plantes espinoses diverses.

"nigrescens": epítet llatí, que significa, que es sembla al negre o es torna de color negre.

"assol": epítet llatinitzat a partir del cognom del botànic aragonès Jordán Claudio de Asso y del Río (1742-1814).

\section{Descripció, ecologia i distribució}

Card de talla moderada (fins a $80 \mathrm{~cm}$ ), de color verd intens i extremadament espinós. Capçaletes florals gruixudes, en forma de copa, amb abundants bràctees espinoses quasi linears, i flors de color rosat intens (de maig a juliol), atractives per a la majoria de papallones diürnes. Habita en pastures i matolls, abundant en les zones cremades. Endemisme ibero-llevantí.

Card verd

Cianotípia sobre gelatina transferida a paper i acrilic 


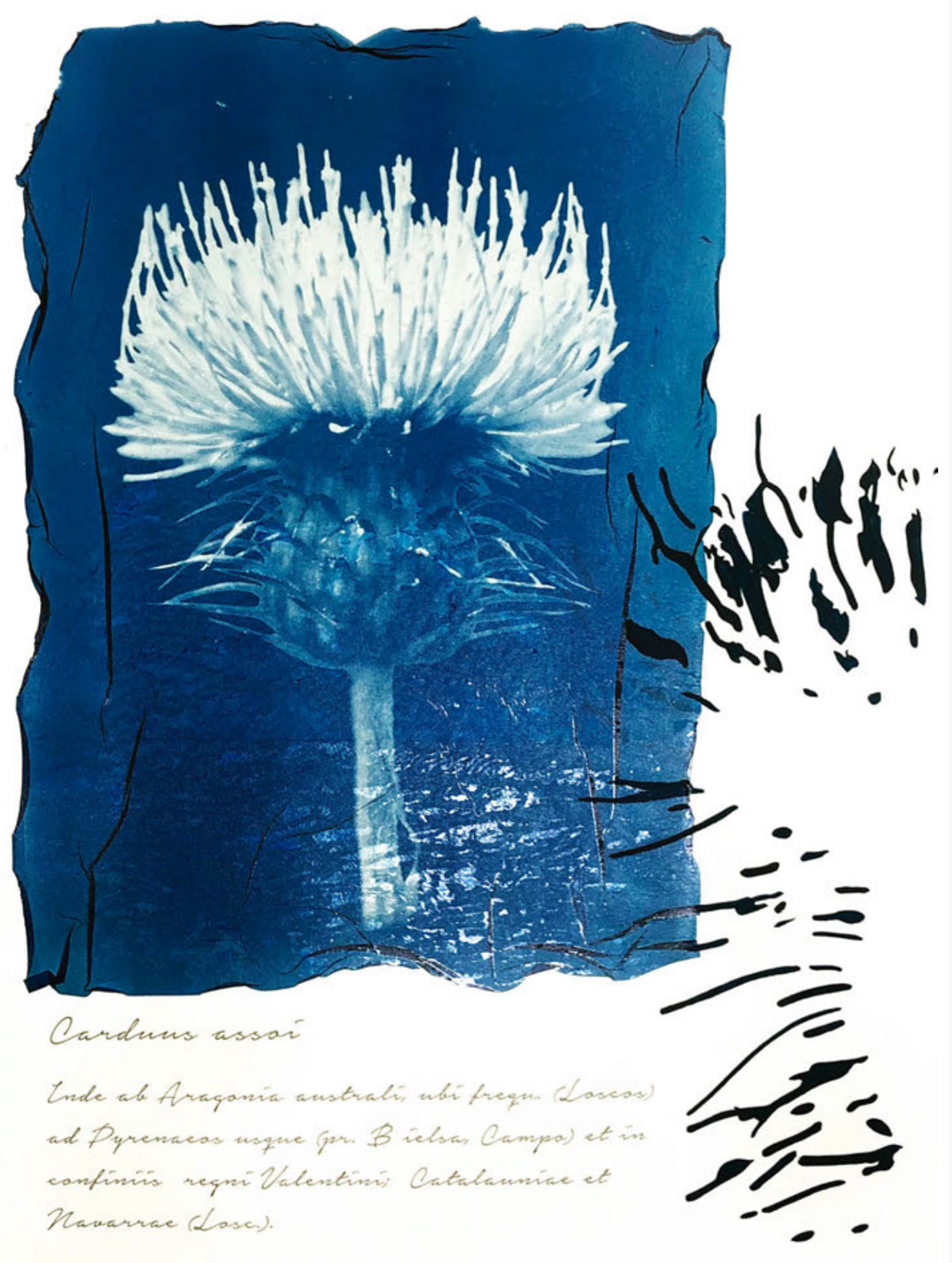




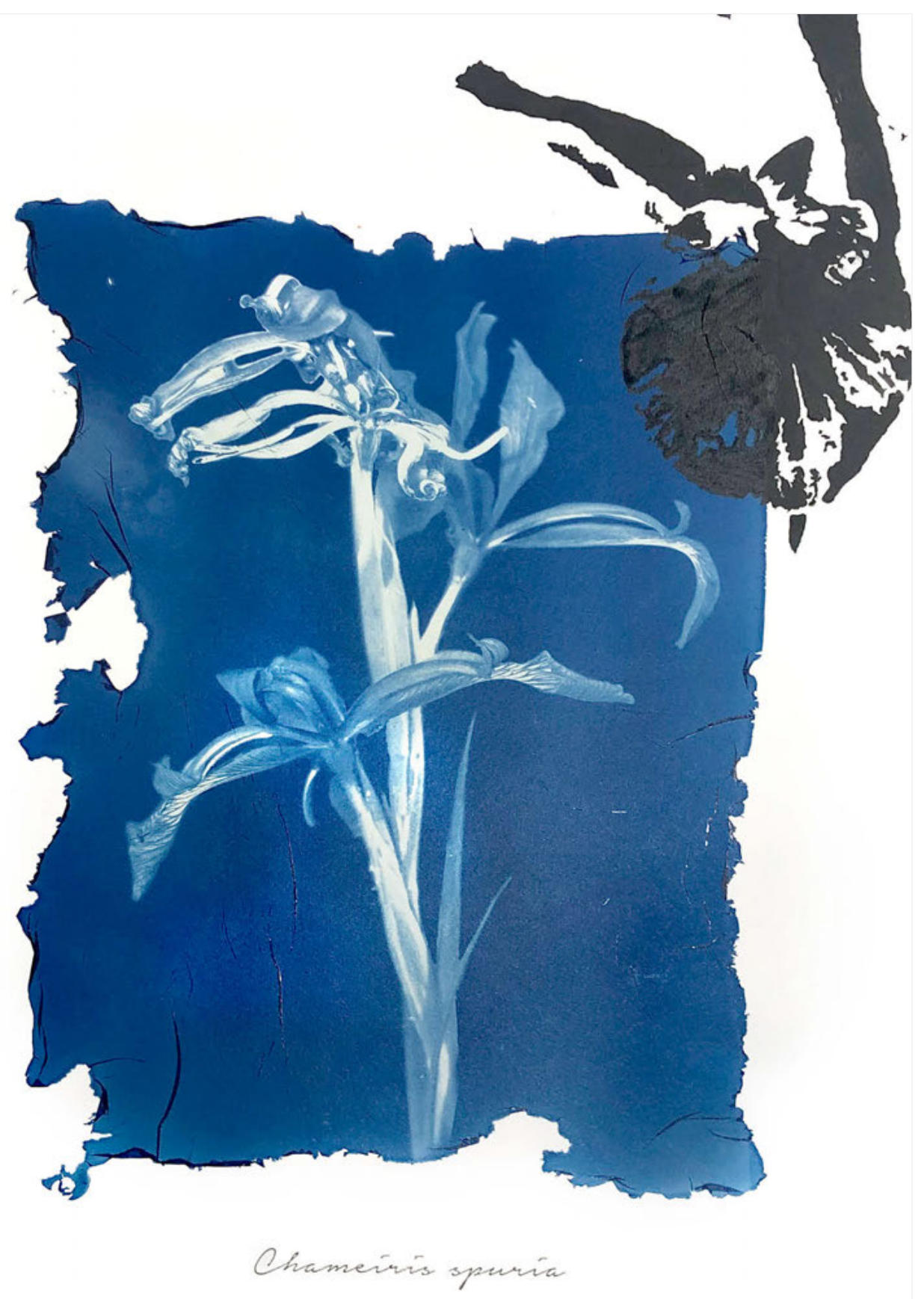




\section{Lliri blau de jonqueres}

Lirio azul de juncales

Chamaeiris reichenbachiana (Klatt) M.B. Crespo

(= Iris spuria L. subsp. maritima (Dykes) P. Fourn.)

Iridàcies

\section{Etimologia}

"Chamaeris": nom genèric, que deriva del noms grecs chamai (=a terra, per terra, que s'arrossega), i iris, -idos, la deessa grega de l'arc de Sant Martí (referint-se a l'extensa varietat de colors que tenen les flors de les espècies incloses en el gènere dels liris).

"reichenbachiana": dedicat al naturalista i botànic alemà Ludwig Reichenbach (1793-1879).

\section{Descripció, ecologia i distribució}

Lliri de fins a $60 \mathrm{~cm}$, molt esvelt, amb fulles planes de color verd fosc i rizoma curt i prim. La vara floral posseeix una o més flors (de Març a Juny), on es combinen el color blau marí, el blanc i el groc. És una espècie molt rara, protegida per la normativa valenciana. Viu en llocs humits però no entollats, prop de fonts o fons de barrancs. Mediterrani.

\section{$<$ Lliri blau de jonqueres}

Clanotípia sobre gelatina transferida a paper i acrilic

$100 \times 70 \mathrm{~cm}$

Stübing 2018 


\section{Gitam, Timó reial}

Tarraguillo, Fresnillo, Dictamo

Dictamnus hispanicus Webb ex Willk.

Rutàcies

\section{Etimologia}

"Díctamnus": nom genèric que prové del grec diktamnos, paraula composta de dike (muntanya homònima de l'illa de Creta) i de thamnos (=arbust).

"hispanicus": epítet geogràfic llatí que fa referència a la seva localització a Hispània.

\section{Descripció, ecologia i distribució}

Herba aromàtica, perenne, amb fulles compostes imparipinnades i coriàcies, de color verd clar. Inflorescència en raïm, proveïda de vistoses flors blanc-rosades (de Maig a Juny). Habita en matolls serials, pastures vivaces i clars de boscos mediterranis, desenvolupats sobre sòls calcaris. Endemisme mediterrani occidental. A causa del abús de la seva recol·lecció en el medi natural, les seves poblacions estan en franc retrocés i actualment aquesta planta és rara o està en perill d'extinció en moltes de les nostres comarques.

\section{Usos}

Les seues sumitats florides s'utilitzen macerades en una barreja d'alcohol i aigua, com a base per a la fabricació de licors digestius, que reben la denominació de "herberets" o "herberos" (quan s'incorporen a més al macerat altres òrgans d'altres plantes); si només es maceren les summitats florides, reben la denominació de "gitam". Els infusos d'eixes summitats florides s'han utilitzat com a abortius i com hipotensors.

\section{Gitam}




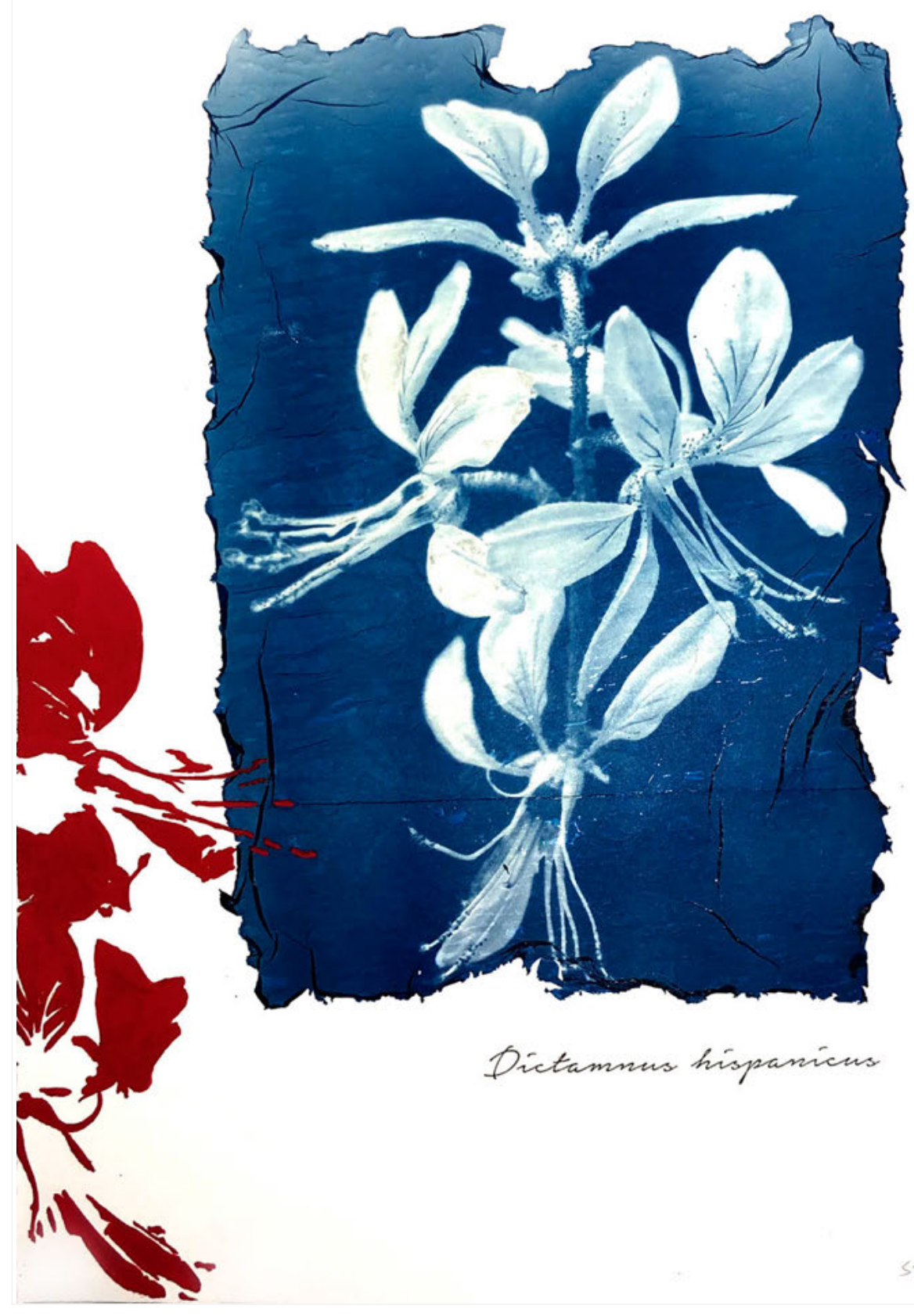




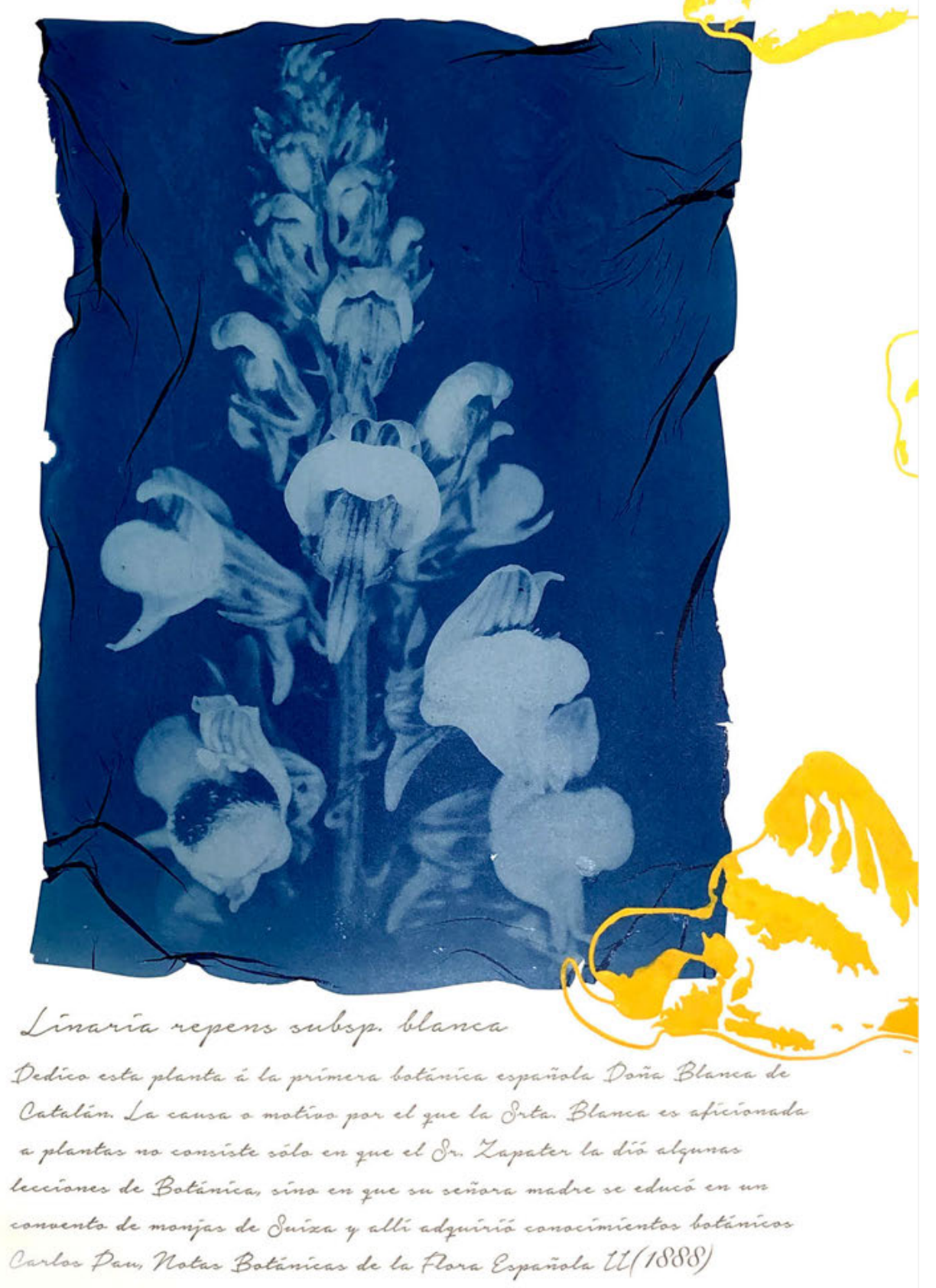




\section{Conillets blancs}

Pajarita blanca, linaria estriada

Linaria repens (L.) Mill. subsp. blanca (Pau) Fern. Casas \& Muñoz Garm.

Escrofulariàcies

\section{Etimologia}

"Linaria": nom genèric que en llatí significa semblança a Linum, pel paregut del seu fullatge amb el del lli.

"repens" : del llatí repens, -entis (reptant, que s'arrossega).

"blanca": epítet atorgat pel seu descobridor, l'insigne botànic sogorbí Carlos Pau (1857 - 1937), en honor a la botànica Blanca Catalán de Ocón.

\section{Descripció, ecologia i distribució}

Herba perenne de color verd-blavós, amb fulles estretes i una mica carnoses. La planta s'agosta cada any, emetent tiges coronades per rams allargats de flors blanquinoses o rosades (de Juny a Octubre), lleugerament oloroses, amb forma de boca de drac. Es tracta d'un endemisme de la meitat oriental de la Península ibèrica, relativament rar, abundant només en runars i vores de camins.

\section{$<$ Conillets blancs}

Cianotípia sobre gelatina transferida a paper i acrilic

$100 \times 70 \mathrm{~cm}$

Stübing 2018 


\section{Tramussera valencia}

Altramuz valenciano

Lupinus mariae-josephae H. Pascual Casas \& Muñoz Garm.

Fabàcies

\section{Etimologia}

"Lupinus": nom genèric derivat del llatí lupinus, pertanyent als Ilops, al seu torn del grec lype (dolor) i lepo; el seu probable significat seria: per als llops, tòxic.

"mariae-josephae": epítet atorgat pel seu descriptor en honor de la valenciana María José Silla Soria.

\section{Descripció, ecologia i distribució}

Herba anual de fins a $40 \mathrm{~cm}$, amb fulles palmades, formant mates denses de les quals sorgeixen les branques florals. Les flors (d'Abril a Juny) combinen els colors blanc i rosat, i donen lloc a llegums que contenen tramussos jaspiats, rugosos i de xicoteta grandària. Viu en clars de matollars sobre sòls calcaris rogencs, descarbonatats en la seua superfície. És un endemisme exclusiu del centre i sud de València i nord d'Alacant, localitzat per primera vegada entre Monserrat i Llombai. 



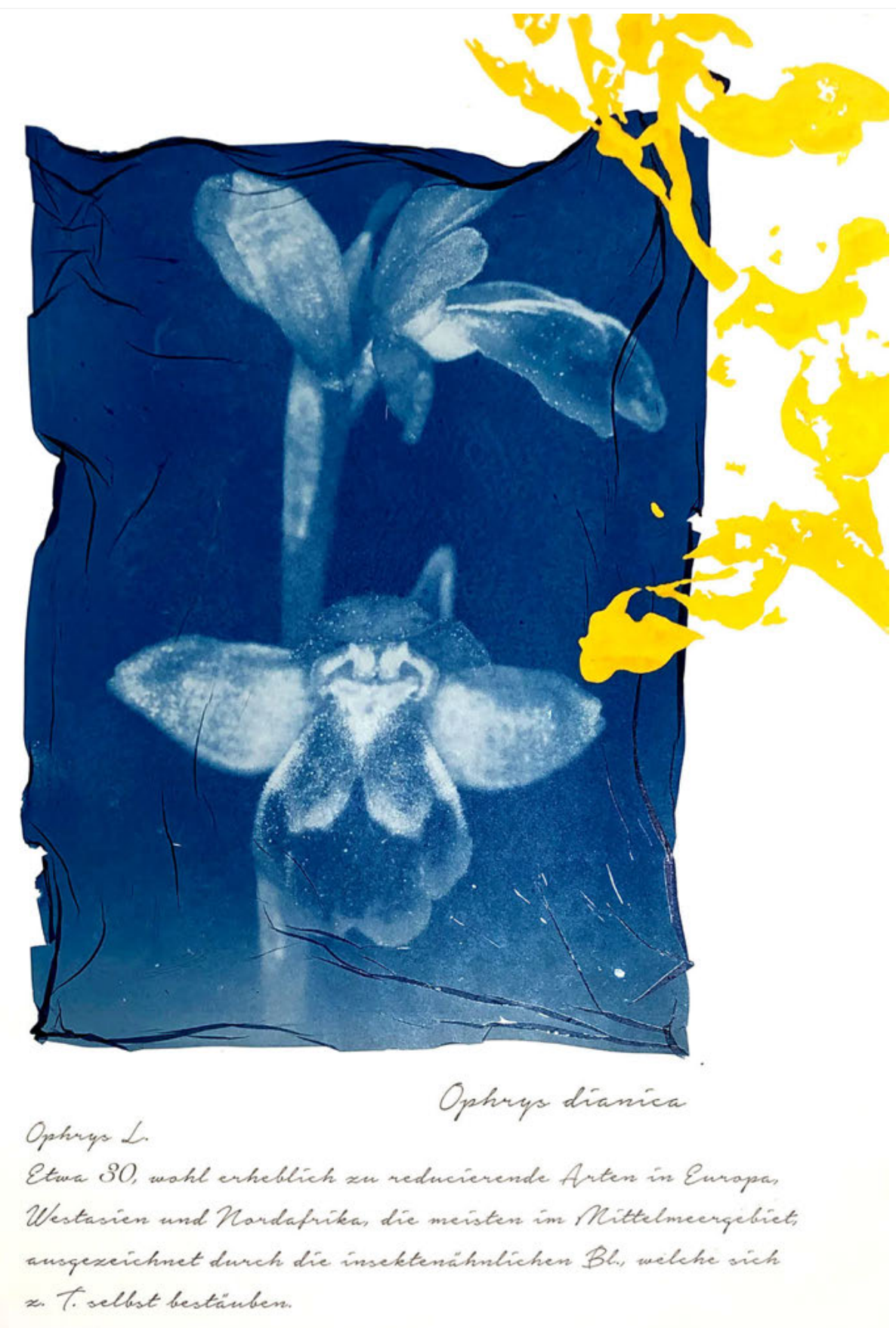




\section{Abellera diànica}

Abejera alicantina, Flor de abeja

Ophrys dianica M.R. Lowe et al.

Orquidàcies

\section{Etimologia}

"Ophrys": epítet d'origen incert, por provindre del grec ophrýs i el llatí ophrys, referit a una planta que tenyia de negre els cabells; o bé del grec ophis (serp), per l'aspecte de llengua de serp del label -peça principal de la flord'algunes orquídies.

"dianica" al·ludeix a la localitat de Dénia.

\section{Descripció, ecologia i distribució}

Orquídia de xicoteta talla, rarament major de $20 \mathrm{~cm}$, amb 2-6 fulles basals amples formant una roseta i dos tubercles subterranis. Emet una tija amb 2-8 flors xicotetes l'aspecte de les quals recorda al de les abelles; la peça principal o label té un dibuix en forma de W i un marcat vorell groc. Viu en clarianes del matoll o del bosc, en pasturatges naturals i en els que es donen en bancals abandonats. És una espècie relativament rara, considerada com a endèmica exclusiva del sud de València i nord d'Alacant, amb òptim en l'última zona citada.

\section{$<$ Abellera diànica}

Cianotípia sobre gelatina transferida a paper i acrilic

$100 \times 70 \mathrm{~cm}$

Stübing 2018 


\section{Abellera olorosa}

Mayos, Abejera olorosa

Anacamptis fragrans (Pollini) R.M. Bateman

Orquidàcies

\section{Etimologia}

"Anacamptis": nom derivat del grec anacámptô, que significa doblegar o torçar, per la forma retorçuda del retinacle, una de les parts dels òrgans masculins de la flor.

Descripció, ecologia i distribució

Orquídia de fins a 50-60 cm, amb 2-4 fulles basals allargades de color verd intens, que sorgeixen de tubercles subterranis. Les flors, són xicotetes i sovint aromàtiques, amb lleugera olor a vainilla, i es disposen en una vara floral allargada. Viu en pasturatges frescos, a vegades en herbassars de bancals abandonats. Encara que es distribueix per tot el Mediterrani, és estranya i es troba protegida en la Comunitat Valenciana. 


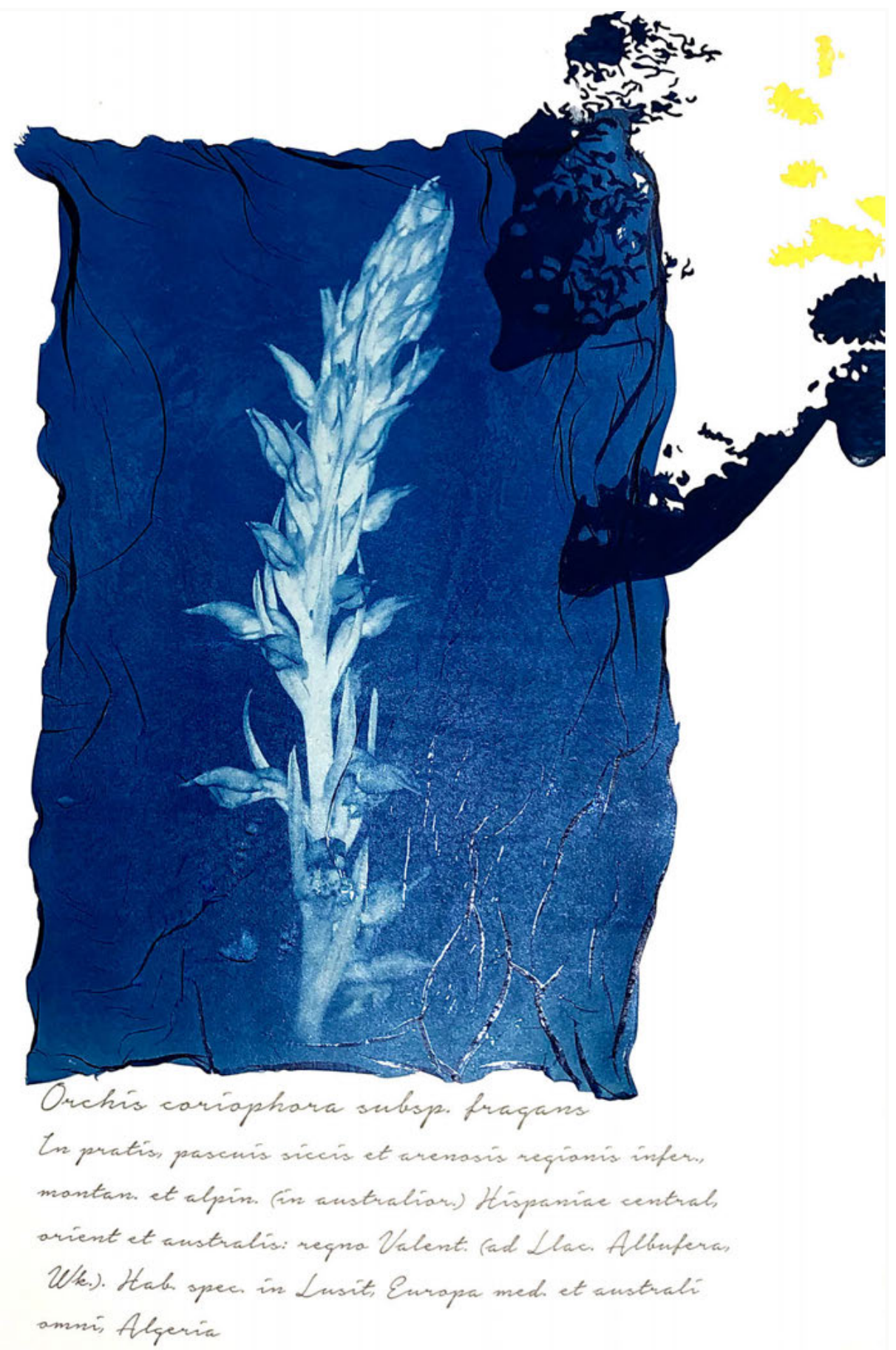




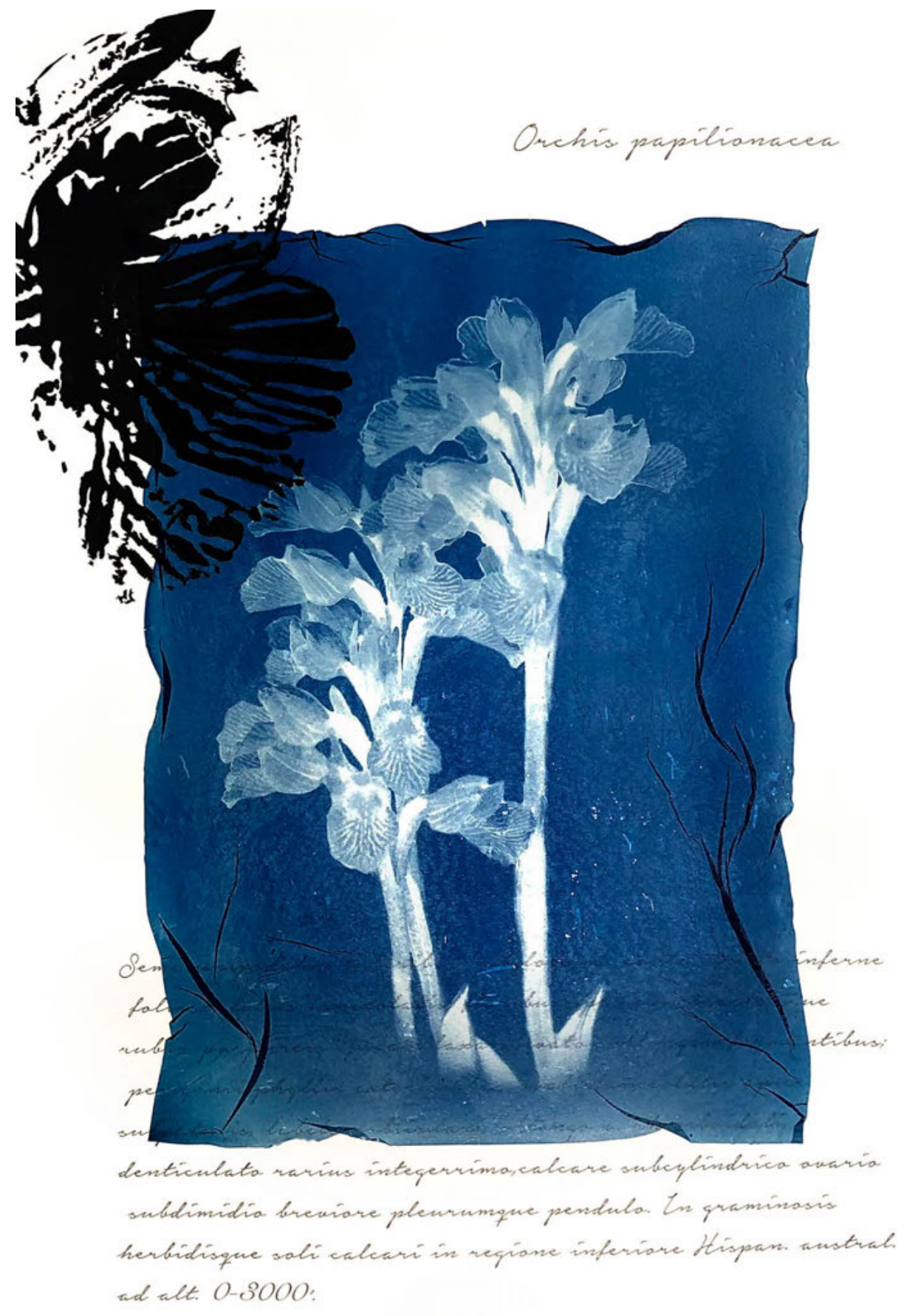




\section{Abellera papallona}

Abellera papallona

Anacamptis papilionacea (L.) R.M. Bateman, Pridgeon \& M.W. Chase subsp. grandiflora (Boiss.)

Kreutz

Orquidàcies

\section{Etimologia}

"Anacamptis": nom derivat del grec anacámptô, que significa doblegar o torçar, per la forma retorçuda del retinacle, una de les parts dels òrgans masculins de la flor.

"papilionacea": derivat del llatí papilio, papallona, per la forma de la flor, que resembla eixos insectes.

"grandiffora": provinent del llatí, s'aplica a les plantes de flors grans.

\section{Descripció, ecologia i distribució}

Orquídia de fins a 30-40 cm amb 2-4 fulles basals allargades, verdoses, formant una roseta de la qual sorgeix la tija, portador de 6-15 flors molt cridaneres, de color rosa intens; són les de major grandària de les orquídies silvestres valencianes. Viu en pasturatges de zones plujoses, sobre sòls sorrencs o descarbonatats. És una de les espècies més amenaçades del territori valencià, estant protegida en la categoria En Perill d'Extinció.

\section{Usos}

La farina dels seus tubercles, denominada "salep", és nutritiva i demulcent; es va utilitzar popularment en uns altres temps per al tractament d'irritacions gastro-intestinals.

\section{$<$ Abellera papallona}

Cianotípia sobre gelatina transferida a paper i acrilic

$100 \times 70 \mathrm{~cm}$

Stübing 2018 


\section{Sàlvia valenciana}

Salvia valenciana

Salvia valentina Vahl

Labiades

\section{Etimologia}

"Salvia": derivat del llatí salvia, -ae, per a designar aquest tipus de plantes, relacionat amb el llatí salvus, -a, -um que significa sencer, sa, amb bona salut, probablement per les amples i reconegudes qualitats curatives de les sàlvies.

"valentina": epítet llatí per a les plantes valencianes.

\section{Descripció, ecologia i distribució}

Herba perenne lleugerament aromàtica que agosta cada any, formant entre la tardor i la primavera següent una nova roseta de fulles verdes, retallades, rugoses i pegades al sòl. Del centre sorgeix una tija coberta de pèls blancs fins, i amb flors de color blavós intens, en forma de casc o cresol, disposades en pisos o verticils. Viu en pasturatges i clars forestals. És una planta endèmica quasi exclusiva del territori valencià, amb òptim en el quadrant sud-est de València i l'interior de Castelló. 


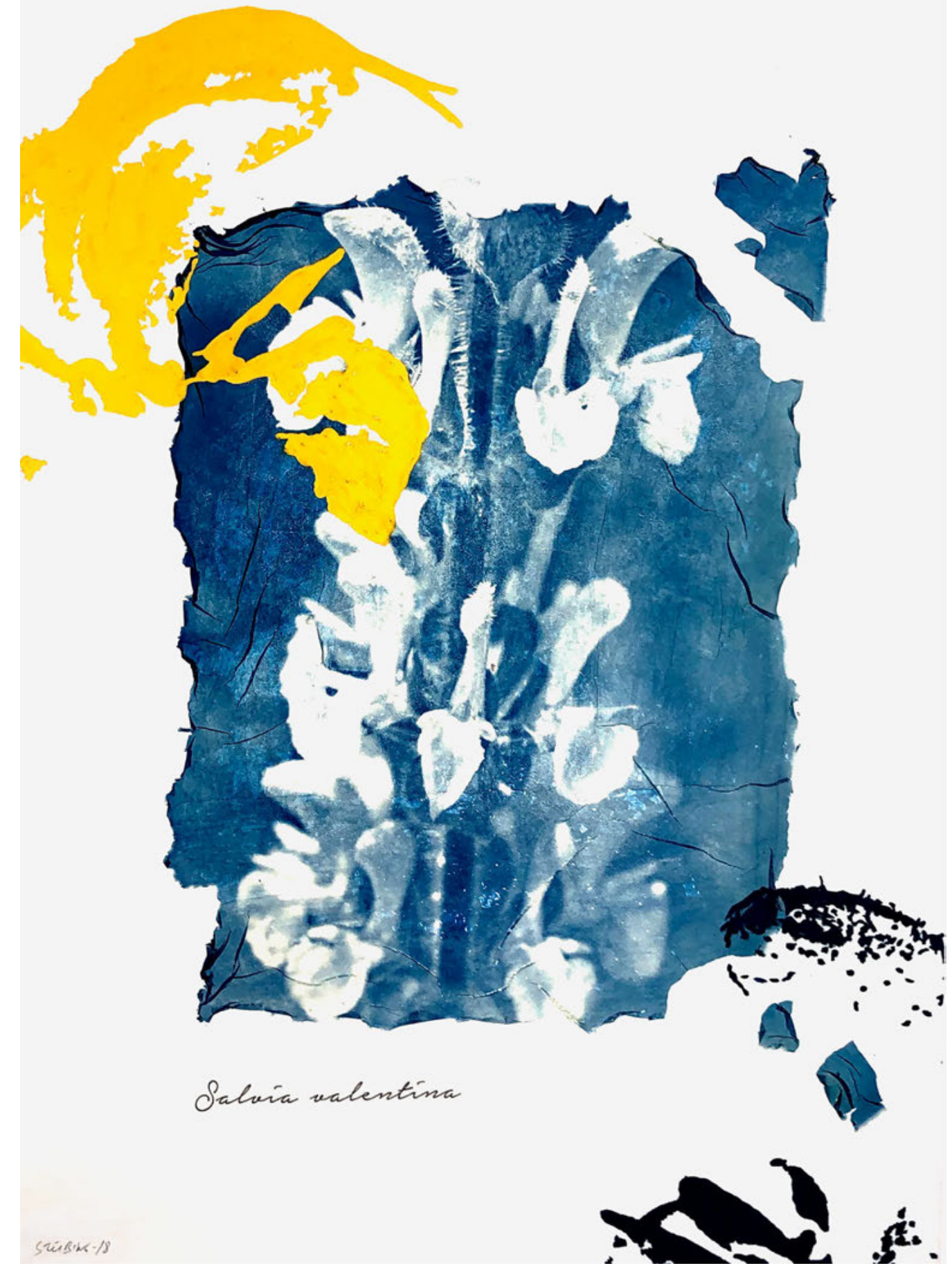




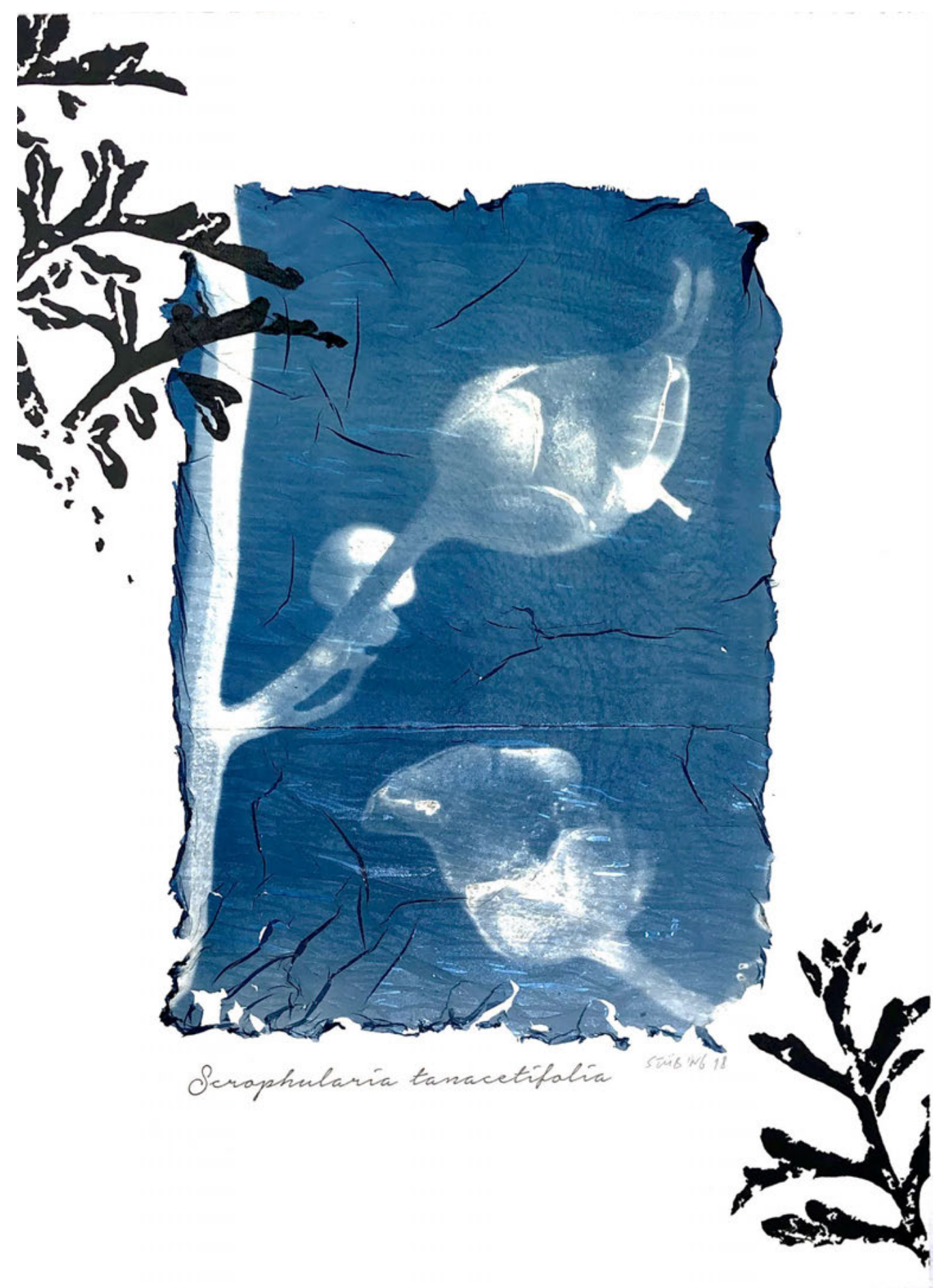




\section{Herba serrada}

Escrofularia fina

Scrophularia tanacetifolia Willd.

Escrofulariàcies

\section{Etimologia}

"Scrophularia": nom genèric derivat del llatí, scrofulae, -arum, escròfules o galteres, i del llatí -aria, -ariae (sufix, que indica relació en sentit ampli) ja que es pensava que les seues arrels proveïdes de nòduls eren útils per a tractar els nòduls o galteres, vulgarment coneguts com a escròfules.

"tanacetifolia": epítet llatí, que significa: amb fulles com les dels herbes cuqueres (gènere Tanacetum).

\section{Descripció, ecologia i distribució}

Herba perenne, sovint agostant, amb fulles molt dividides i tiges quadrangulars, que en el seu extrem porten grups de flors xicotetes, de color vermellós intens. Es tracta d'un endemisme exclusiu de la part oriental de la Península ibèrica, més abundant en la zona central i meridional de València i en el nord d'Alacant. Viu en runars al peu de cingles, als fons de barrancs, i de vegades en cunetes pedregoses, sense ser mai molt abundant. .

$<$ Herba serrada

Cianotípia sobre gelatina transferida a paper i acrlic

$100 \times 70 \mathrm{~cm}$

Stübing 2018 


\section{Cua de gat rosada}

Rabogato rosado

Sideritis regimontana subsp. edetana

(Pau ex Font Quer) M. B. Crespo \& Mateo

Labiades

\section{Etimologia}

"Sideritis": nom genèric que deriva del grec sideritis, que significa "el que és o té ferro", denominació que es donava en general a les plantes capaces de curar ferides causades per armes de ferro.

"edetana" epítet llatí geogràfic, que fa referència als habitants pre-romans que van viure en el territori d'Edeta o l'Edetània (pertanyent a la Hispània tarragonina i que actualment es correspon amb part del territori de la Comunitat Valenciana).

\section{Descripció, ecologia i distribució}

Herba perenne de baixa talla, lleugerament aromàtica, amb una part basal llenyosa i coberta de xicotetes fulles blanquinoses, i tiges una mica més elevats que porten les inflorescències. La flors (de Maig a Agost) són xicotetes, blanques o rosades, disposades en pisos o verticils. Aquesta espècie és endèmica del centre i sud de la província de València, encara que arriba a ser abundant en matollars baixos exposats a la insolació prolongada. 


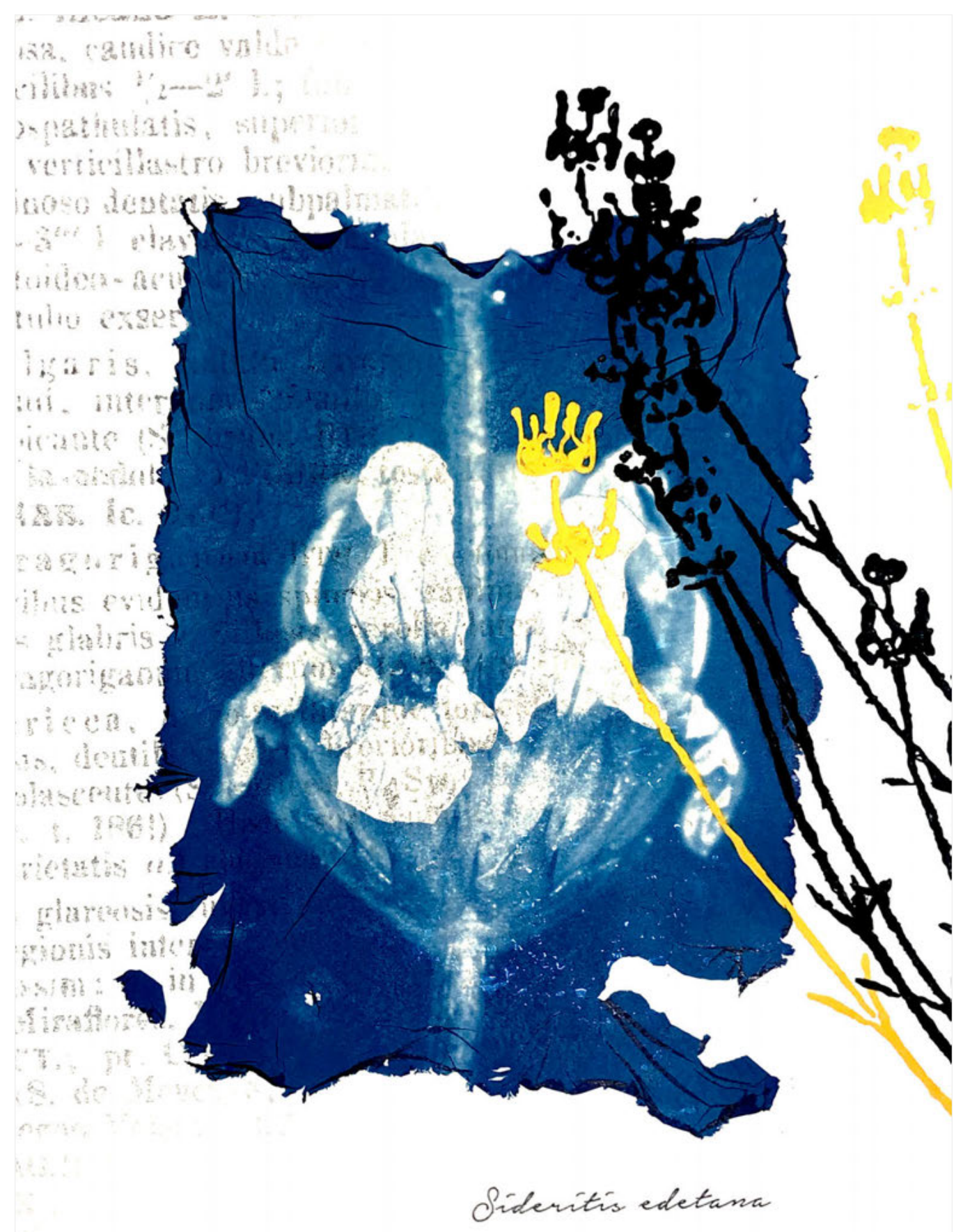




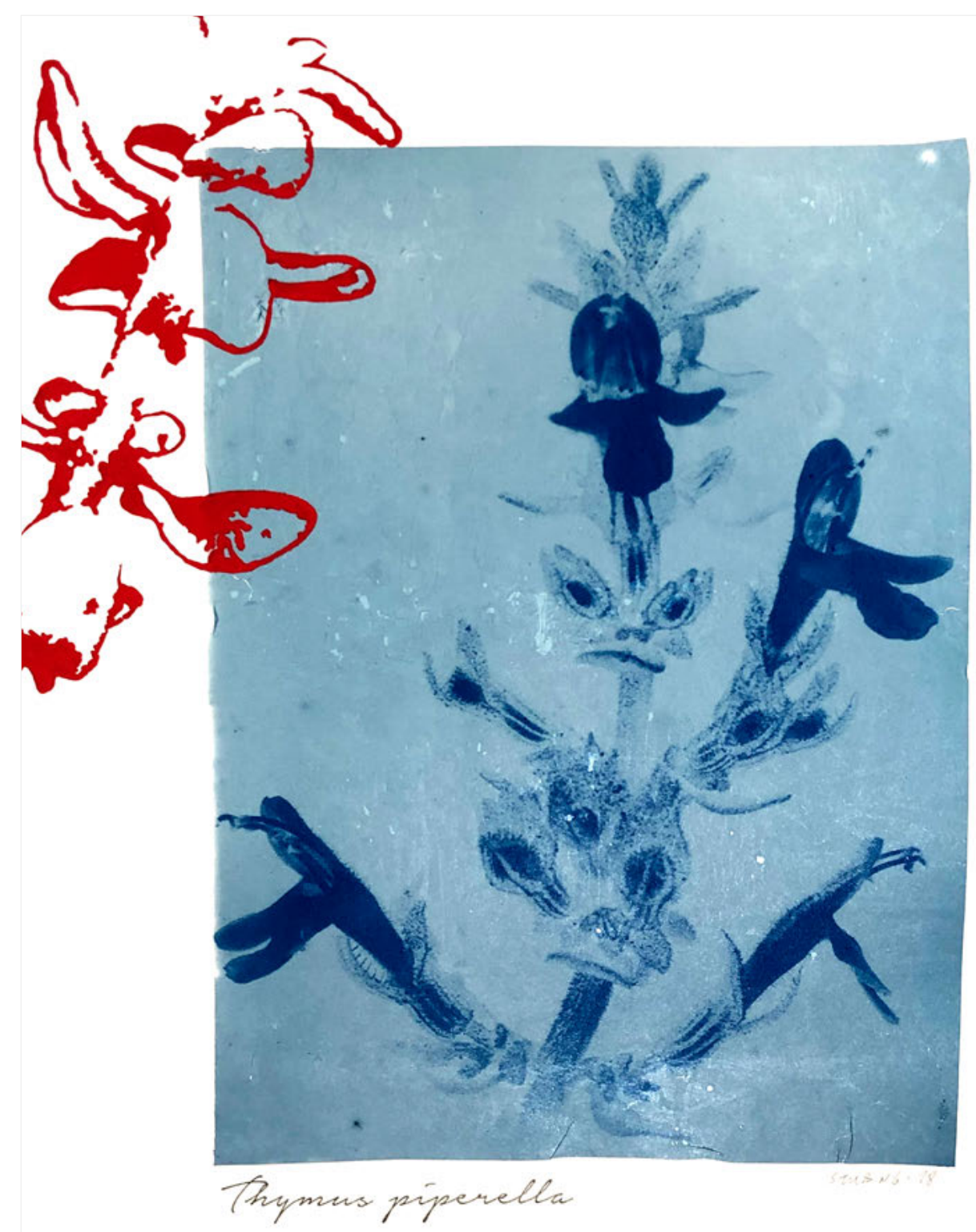

Falis subpetialatis natundis us avatoratundatis abtusis, subtus walde nervasis, nervis lateralibus enratis, caulinisex axillis namulas faliasos edentibus. 


\section{Pebrella, Pebrerola}

Pimentera, Pebrella

Thymus piperella L.

Labiades

\section{Etimologia}

"Thymus": nom genèric que prové de les paraules gregues thymon i thymos que és la denominació donada a aquestes plantes.

"piperella": epítet llatí, que significa "pebre", al·lusiu al seu sabor picant.

\section{Descripció, ecologia i distribució}

Xicotet arbust aromàtic, d'olor característica semblant al de l'orenga o la sajolida, dels quals es diferencia bé per les seues fulles, una mica rígides i amb aspecte de cullera. Les flors (de Juliol a Novembre) són rosades i es reuneixen en grups al final de les tiges. És un dels endemismes més característics del territori valencià, sent de vegades abundant als matollars i al sotabosc de pinedes.

\section{Usos}

La summitat aèria és rica en oli essencial d'ús en fitoteràpia. Les seues fulles es fan servir com a espècia culinària i condimentària. En xicoteta quantitat s'usa per assaonar carns; a més d'aromatitzar-les, estimula la secreció gàstrica per via reflexa, facilitant la digestió. És component fonamental dels amaniments per a olives i altres vegetals en salmorra. Els seus infusos es preparen per a combatre la tos.

$<$ Pebrella

Cianotípia sobre gelatina transferida a paper i acrilic

$100 \times 70 \mathrm{~cm}$

Stübing 2018 


\section{Bruc de roca}

Brezo de roca

Erica terminalis Salisb.

Ericàcies

\section{Etimologia}

"Erica": nom derivat del grec erike, llatinitzat com erice: bruc o bruguera, en general.

"terminalis": epítet específic, referent a que les seues flors es disposen en umbel·les terminals.

\section{Descripció, ecologia i distribució}

Arbust perenne del grup dels brucs, amb petites fulles amb forma d'acícules, de color verd grisenc, i flors (de Juny a Octubre) agrupades al final de les branques, apareguent al final de la primavera o ja a l'estiu. Com en altres brugueres, les flors tenen forma de copa invertida o urna, variant el seu color del blanc al rosat intens. Creix en ambients ombrívols interiors, cingleres, balmes i altres afloraments rocosos calcaris. Mediterrani-Occidental. 


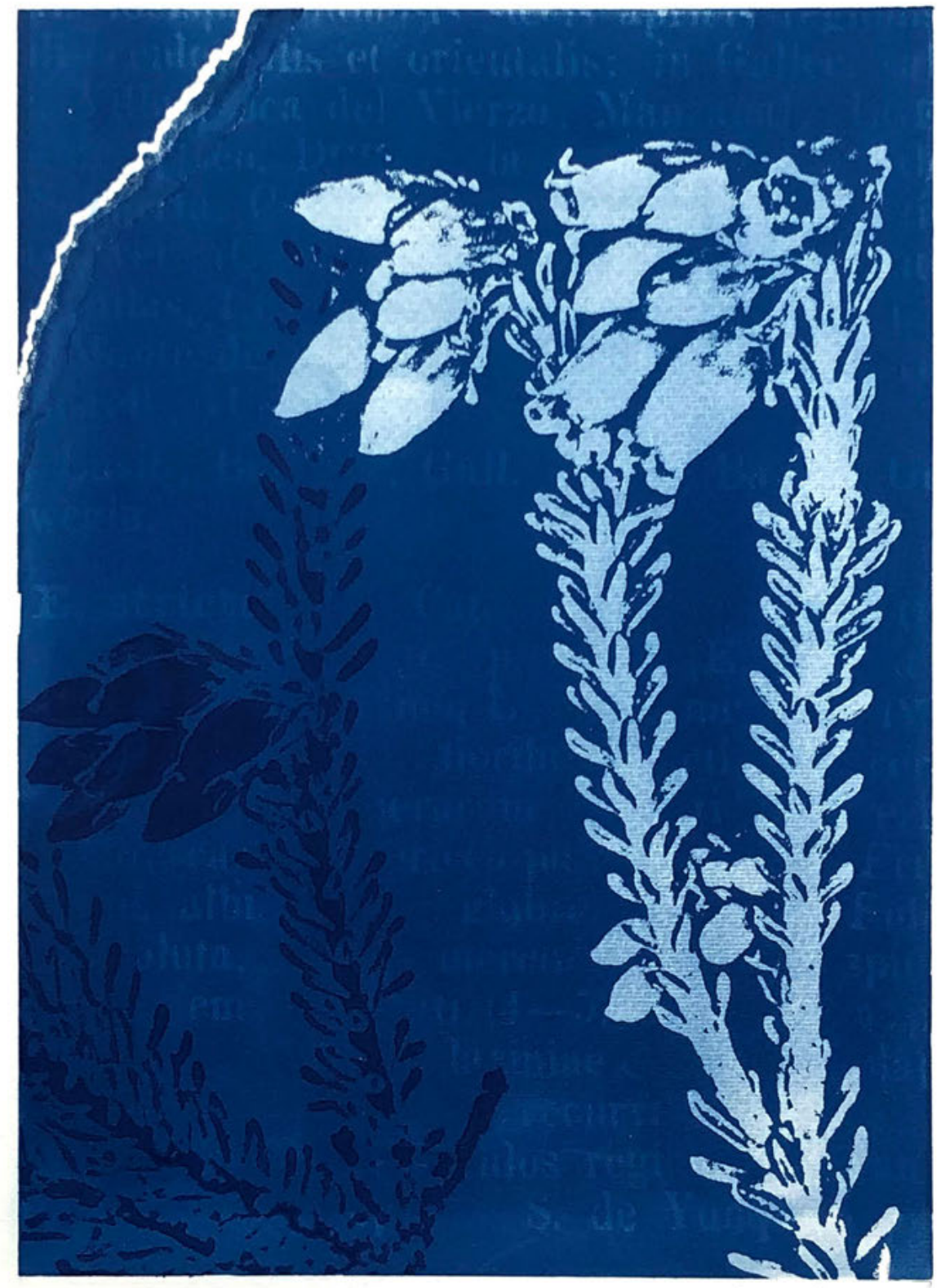




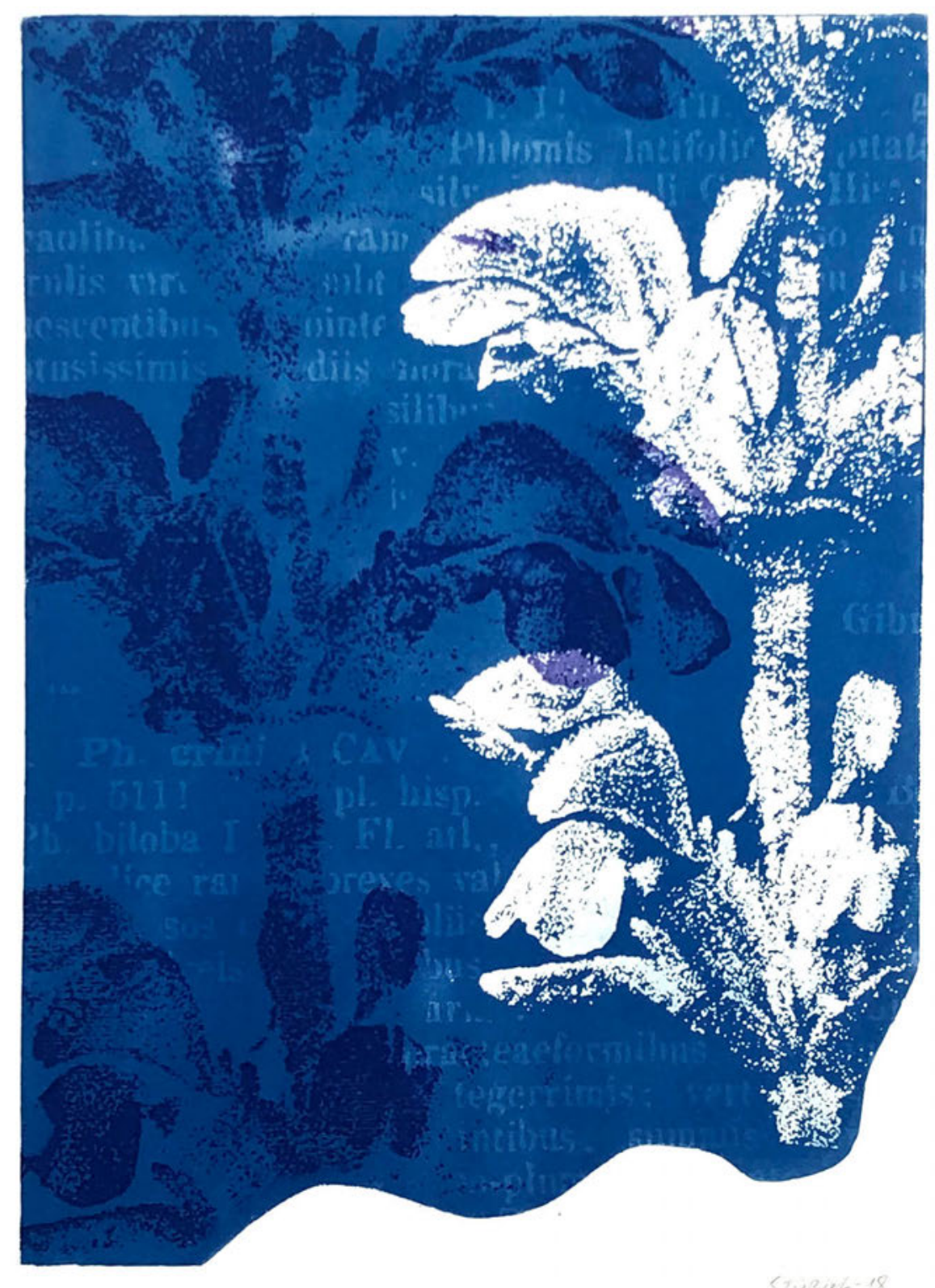




\section{Gresolera metxera}

Barbas de macho, Orejas de burro

Phlomis crinita Cav. subsp. crinita

Labiades

\section{Etimologia}

"Phlomis": nom genèric derivat del grec phlóx (flama) substantiu relacionat amb el verb grec phlégo (encendre, cremar), referit a la forma de les flors, pareguda als cresols o gresols.

"crinita": epítet llatí, que significa "peluda, amb llargs pèls".

\section{Descripció, ecologia i distribució}

Arbust perenne amb fulles basals amples i allargades, blanquinoses, d'aspecte llanós, disposades en tiges curtes. A la primavera emet tiges més elevades portadores de les flors (Maig a Juliol), de color ataronjatmarró, amb forma de cresol, disposades en pisos (verticils). Habita en matollars secs i assolellats en terrenys calcaris. Aquesta espècie és endèmica ibero-llevantina, exclusiva del territori valencià i zones pròximes de Múrcia i La Manxa. Va ser descrita pel botànic valencià Antonio José Cavanilles (1745-1804).

\section{Usos}

Es van utilitzar les seues fulles per a confeccionar metxes de cresol.

$<$ Gresolera metxera

Cianotípia sobre paper

$70 \times 50 \mathrm{~cm}$

Stübing 2018 


\section{Camamilla amarga}

Manzanilla amarga, Abrótano hembra

Santolina chamaecyparissus subsp. squarrosa (DC.) Nyman

Asteràcies

\section{Etimologia}

"Santolina": nom genèric que deriva del llatí sanctus (= sagrat), i linum (= lii, llinassa), basat en un antic nom d'una espècie d'aquest gènere.

"chamaecyparissus": vocable llatí, derivat del grec, significa "xiprer del sòl".

"squarrosa": epítet derivat del llatí squarrosus,-a, -um, que fa referència a superfícies recobertes d'escates.

\section{Descripció, ecologia i distribució}

Arbust aromàtic, dens, de fins a $40-50$ cm, de color verd una mica grisenc, amb fulles xicotetes, rugoses i aromàtiques. Les seues branques acaben en capçaletes amb forma de copa ampla, coronades per flors (Juny a Setembre) de color groc intens. És freqüent en tot el Mediterrani Occidental, formant part de matollars exposats al sol, i abundant sobretot en vores de pistes i senderes.

\section{Usos}

Els seus capítols popularment s'utilitzen en infús, per les seues propietats antiespasmòdicas antiinflamatòries, antisèptiques i vermifugues, en disturbis digestius i parasitosis En ús extern l'infús dels seus capítols s'ha usat popularment per a rentar els ulls, per les seues propietats antisèptiques i antiinflamatòries, per a tractar la conjuntivitis. Tota la planta té un intens sabor amarg-salí. 


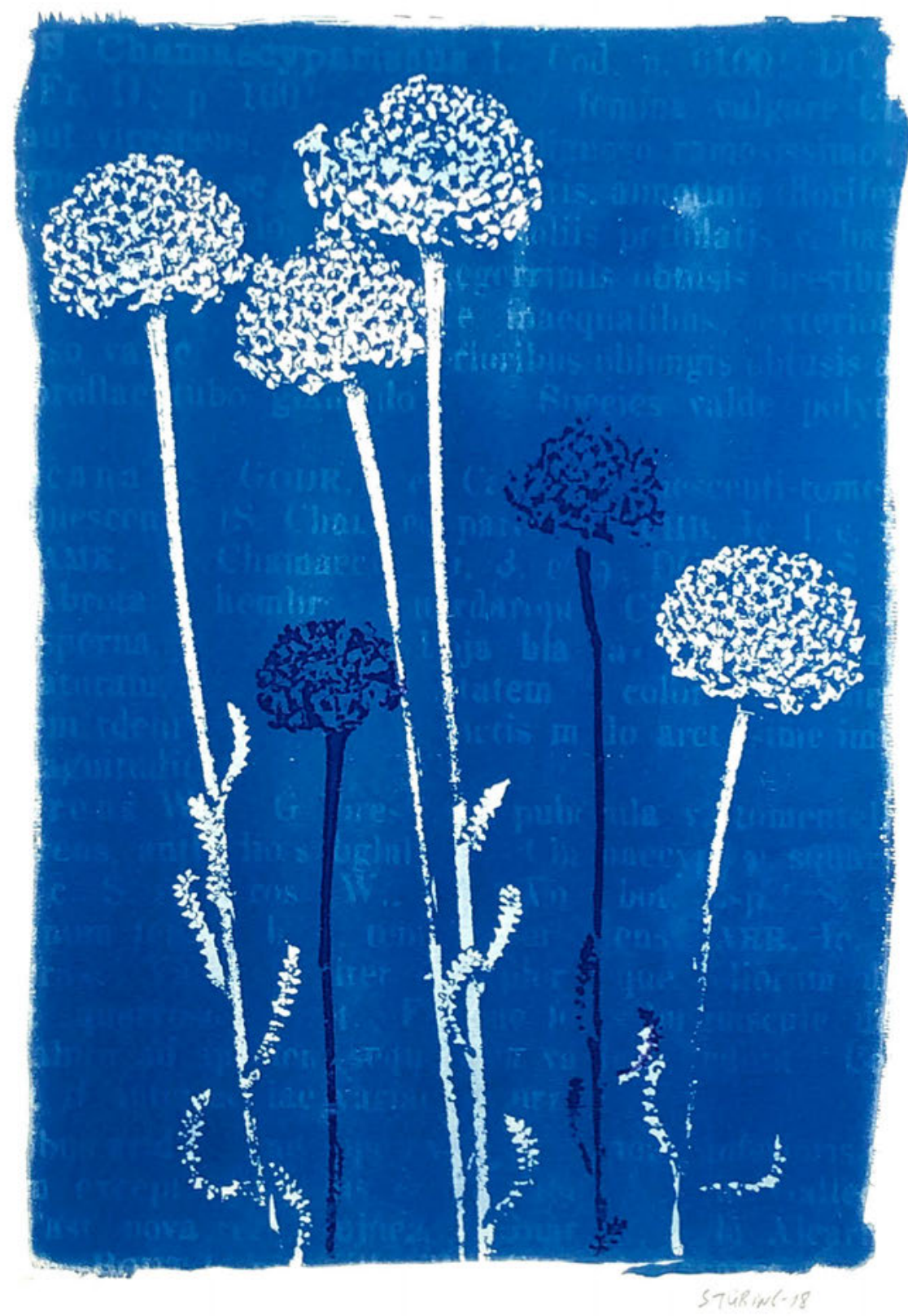




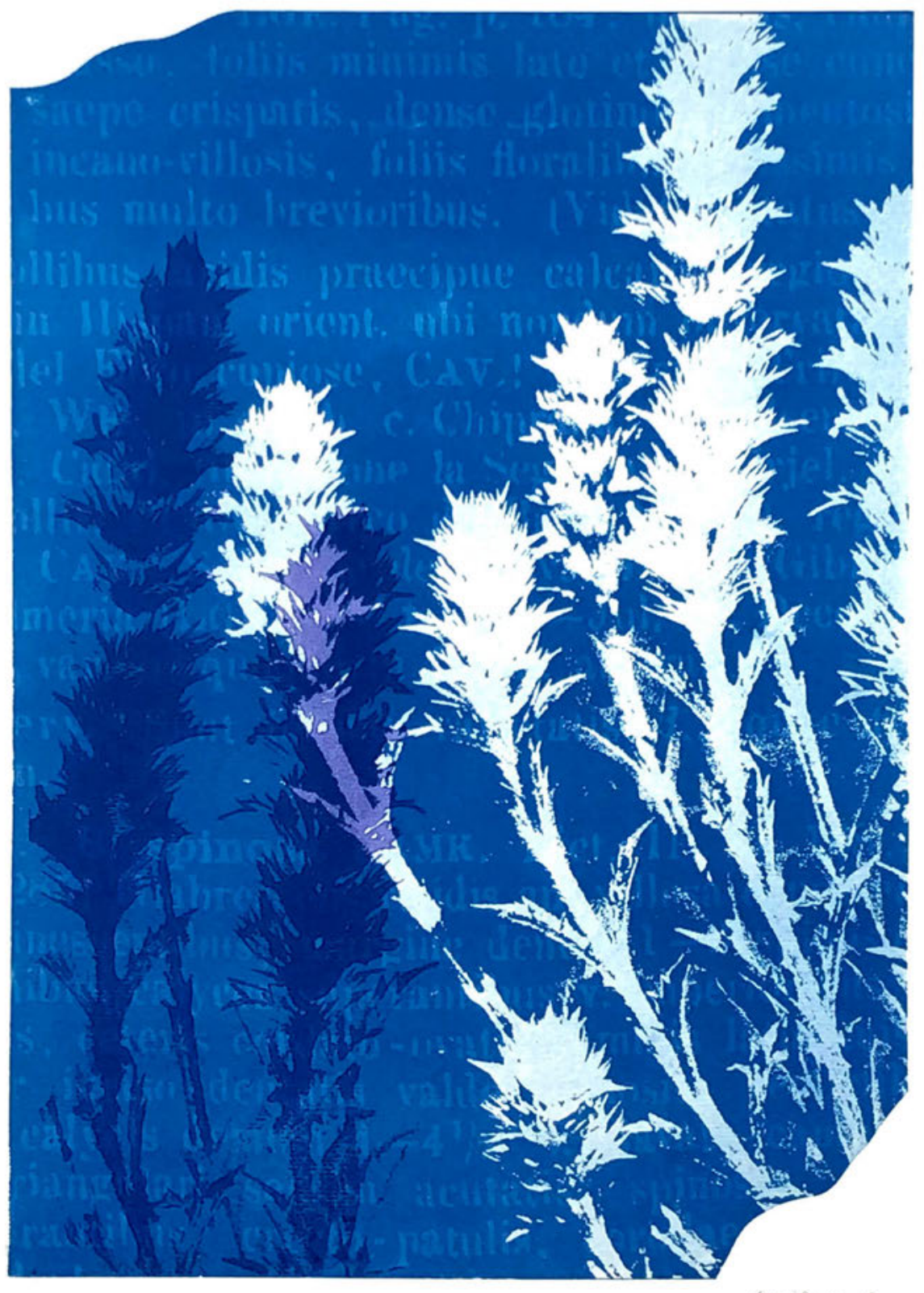




\section{Rabet de gat, Cua de gat}

Rabogato

Sideritis tragoriganum Lag. subsp. tragoriganum

Labiades

\section{Etimologia}

"Sidenitis": nom genèric que deriva del grec sideritis, que significa "el que és o té ferro", denominació que es donava en general a les plantes capaces de curar ferides causades per armes de ferro.

"tragoriganum": en latín, en llatí, al|lusiu a un tipus de timó.

\section{Descripció, ecologia i distribució}

Arbust aromàtic d'intensa olor, de fins a $40-50 \mathrm{~cm}$, amb branques denses i més o menys paralleles, cobertes de fulles allargades i punxoses en el seu extrem. Floreix en la primavera (Març a Juny), exhibint inflorescències allargades amb les flors groguenques que es disposen en pisos o verticils, cobertes en la seua base per fulletes o bràctees espinoses. Creix en matollars secs i assolejades en zones litorals o subcontinentals. Endemisme de la part central i meridional del territori valencià i les zones pròximes de comunitats autònomes veïnes.

\section{Usos}

Amb els seus summitats florides es preparen infusos com a antiinflamatoris, antisèptics i antiespasmòdics, per al tractament de problemes digestius i urinaris. En ús extern, en el tractament de dermatosis i ferides, el seu infús s'usa com a vulnerari, antisèptic i antiinflamatori.

$<$ Rabet de gat

Cianotípia sobre paper

$70 \times 50 \mathrm{~cm}$

Stübing 2018 


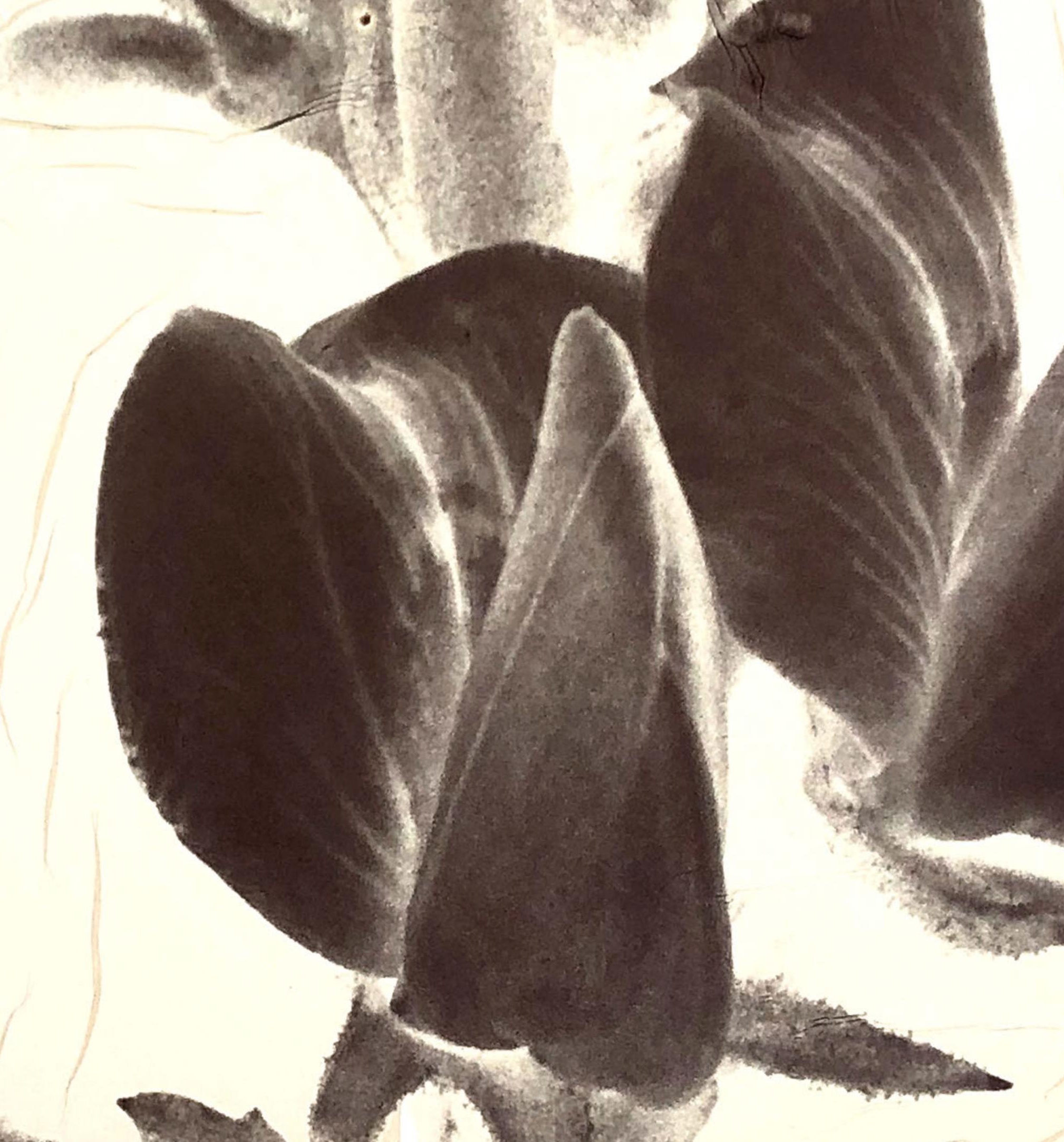




\section{A R G I R O TÍP।E S}

Procés de recent invenció per Mike J. Ware, basat en una tècnica antiga anomenada argentotípia (Herschel 1842), però que aconsegueix major qualitat i durada de les imatges.

El procés és similar al descrit per al cas de les cianotípies, però en el seu lloc s'obté una imatge de color marró més o menys fosc, de la qual és responsable la plata que queda fixada en les zones exposades.

Així s'obté una imatge monocroma anomenada argirotip, amb una àmplia gamma tonal de marrons foscos, quasi negres depenent de diversos factors, sobretot de l'estat d'hidratació del suport. 


\section{Xara d'escurar, estepa blanca}

Jara blanca, estepa blanca

Cistus albidus L.

Cistàcies

\section{Etimologia}

"Cistus": nom genèric que deriva del grec Kisthós, llatinitzat com cisthos, que es va donar a diverses espècies d'estepes, plantes del gènere Cistus L. Alguns autors pretenen relacionar-la, per la forma dels seus fruits amb la paraula grega Kiste (=caixa, cistella).

"albidus": epiteto específic que fa referència a l'aspecte blanquinós de la planta.

Descripció, ecologia, i distribució

Arbust perennifoli de fulles grisenques que sol arribar a $1 \mathrm{~m}$ de talla, amb olor una mica resinós. Flors vistoses i grans de color rosat (de Març a Juny), amb 5 pètals, sovint arrugats com els de les roselles. És freqüent en tot tipus de matollars i el sotabosc obert de pinedes, i sovint es fa més abundant després dels incendis forestals. Exclusiva dels països de la Mediterrània Occidental i Central.

\section{Usos}

Les seves fulles seques s'han utilitzat com a succedani del tabac.

\section{Estepa blanca}

Argirotípia sobre gelatina transferida a paper 


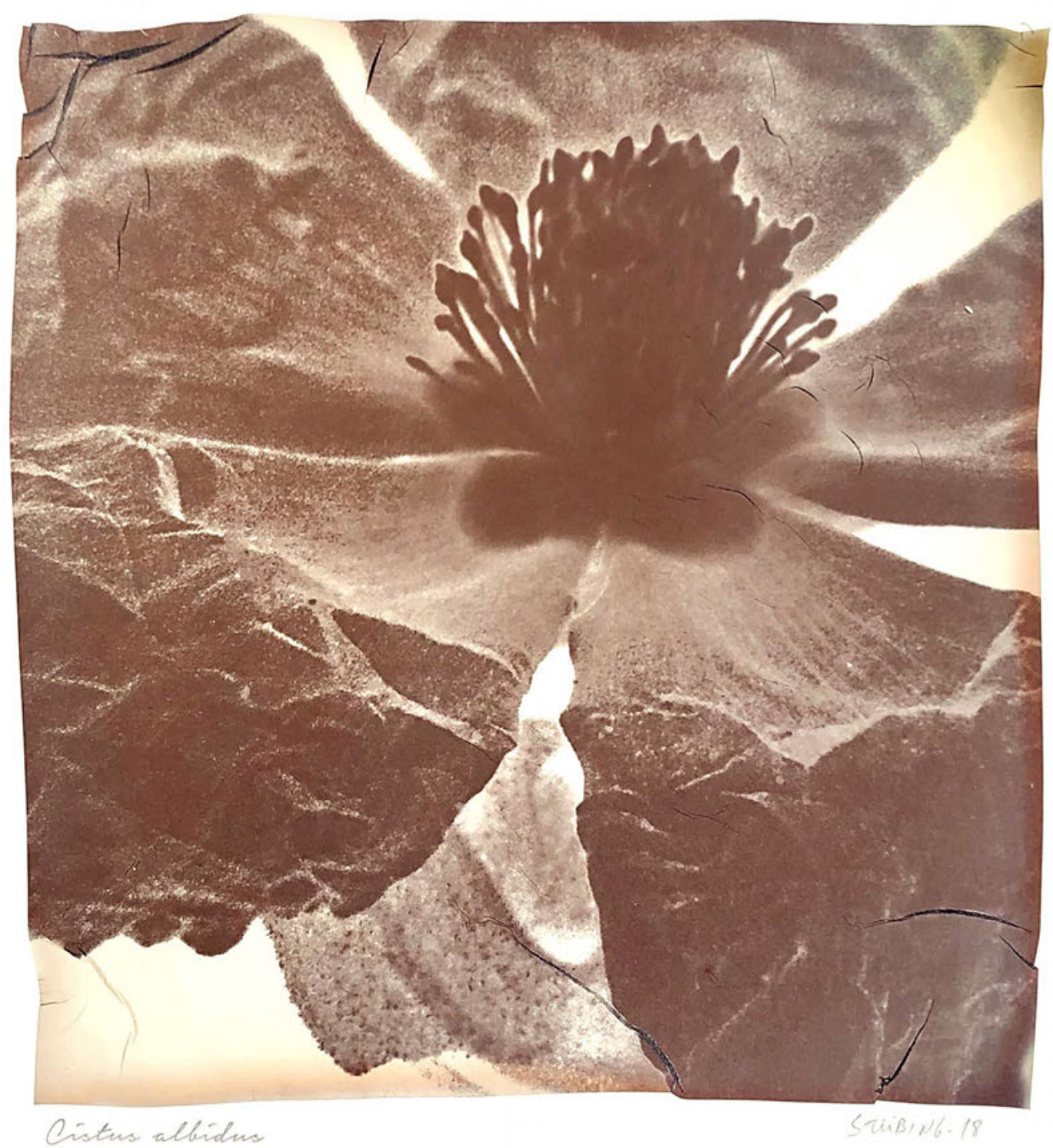




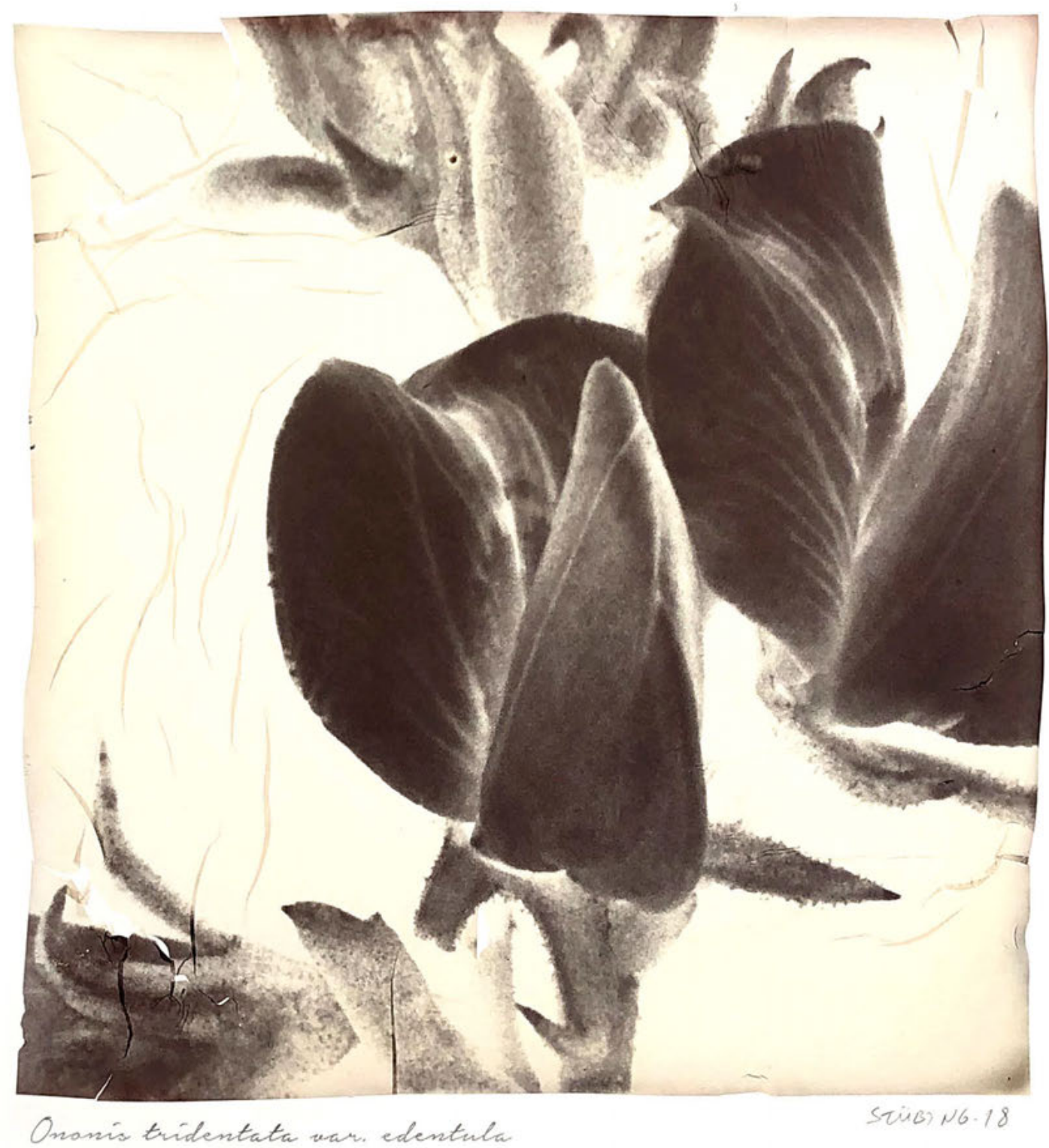




\section{Gavó salat, Arnalls, Ruac}

Arnacho, Asnallo

Ononis tridentata subsp. angustifolia (Lange) Deve-

sa \& G. López (=O. tridentata var. edentula Webb)

Fabàcies

\section{Etimologia}

"Ononis": nom genèric llatí, derivat del grec clàssic, per a denominar plantes amb tiges llenyoses, amb fulles trifoliades amb folíols dentats.

"tridentata": epítet llatí que significa amb tres dents

"angustifolia": del llatí angustus (estret), de fulla o folíols estrets.

\section{Descripció, ecologia i distribució}

Arbust de fins a $1 \mathrm{~m}$ de talla, amb branques portadores de fulles quasi cilíndriques allargades, carnoses, acabades en 1 o 3 dents. Les tiges acaben en flors (de Maig a Novembre) de color rosat, que donen Iloc a llegums curtes amb 1 o 2 llavors. És una espècie endèmica de la part oriental de la Península ibèrica, exclusiva dels afloraments d'algeps, on pot arribar a ser la planta dominant del paisatge.

$<$ Gavó salat

Argirotípia sobre gelatina transferida a paper.

$50 \times 50 \mathrm{~cm}$

Stübing 2018 


\section{Gavó bord}

Garbancillera borde

Ononis fruticosa L.

Fabàcies

\section{Etimologia}

"Ononis": nom genèric, derivat del grec clàssic, per a denominar plantes amb tiges llenyoses, amb fulles trifoliades amb folíols dentats.

"fruticosa": epítet llatí que significa "arbustiva"

\section{Descripció, ecologia i distribució}

Arbust usualment caducifoli, amb fulles xicotetes, allargades, amb dents en la seua vora. Les tiges són sovint arquejades, blanquinoses o rogenques, i acaben en grups de flors de color rosat (de Maig a Juliol), que després de la fecundació produeixen xicotets llegums pareguts als dels cigrons, però amb llavors menors. Les fulles i fruits solen ser apegaloses al tacte. És pròpia de matollars i pinedes del Mediterrani Occidental, abundant més en la zona ibero-llevantina. 


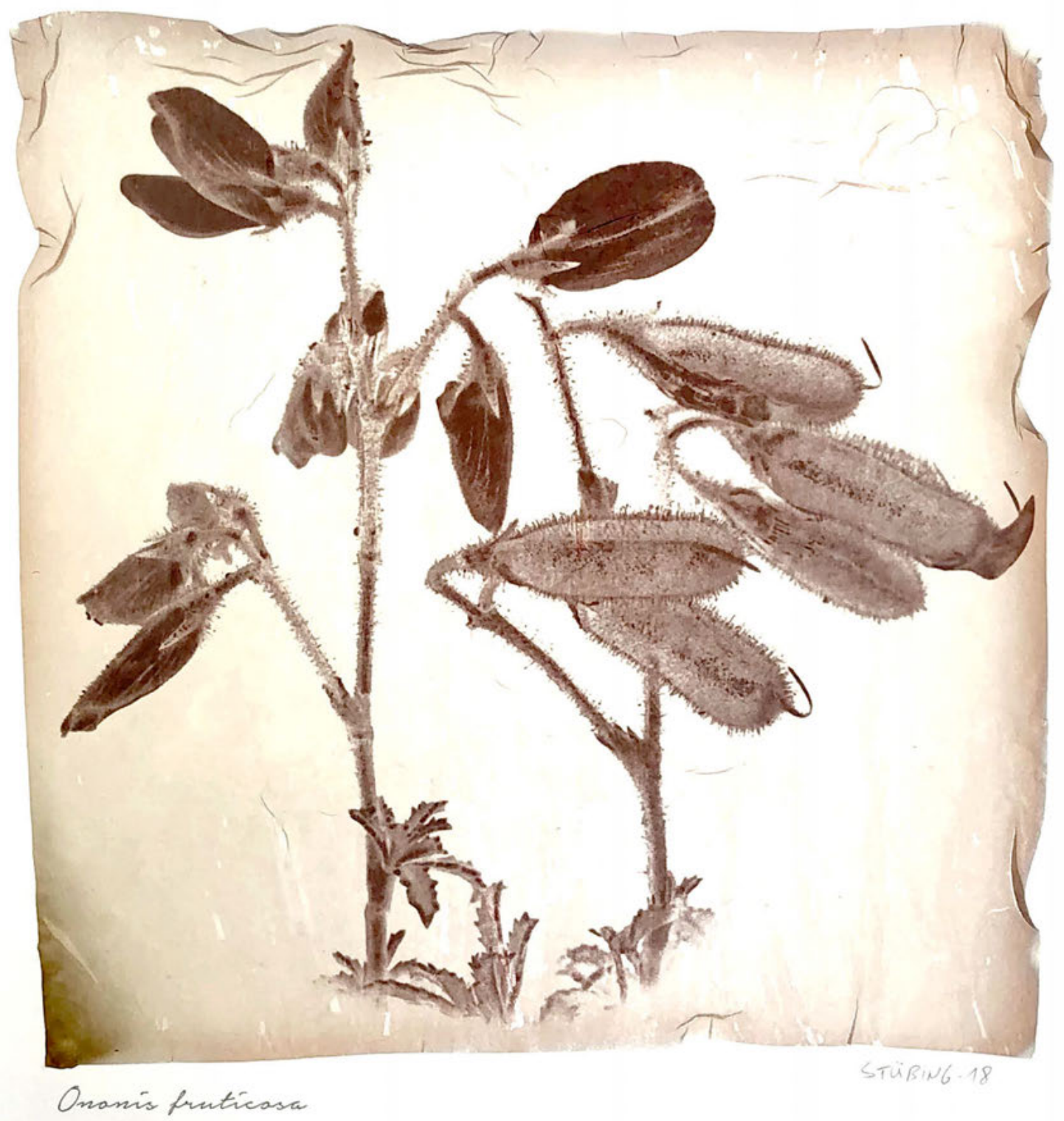




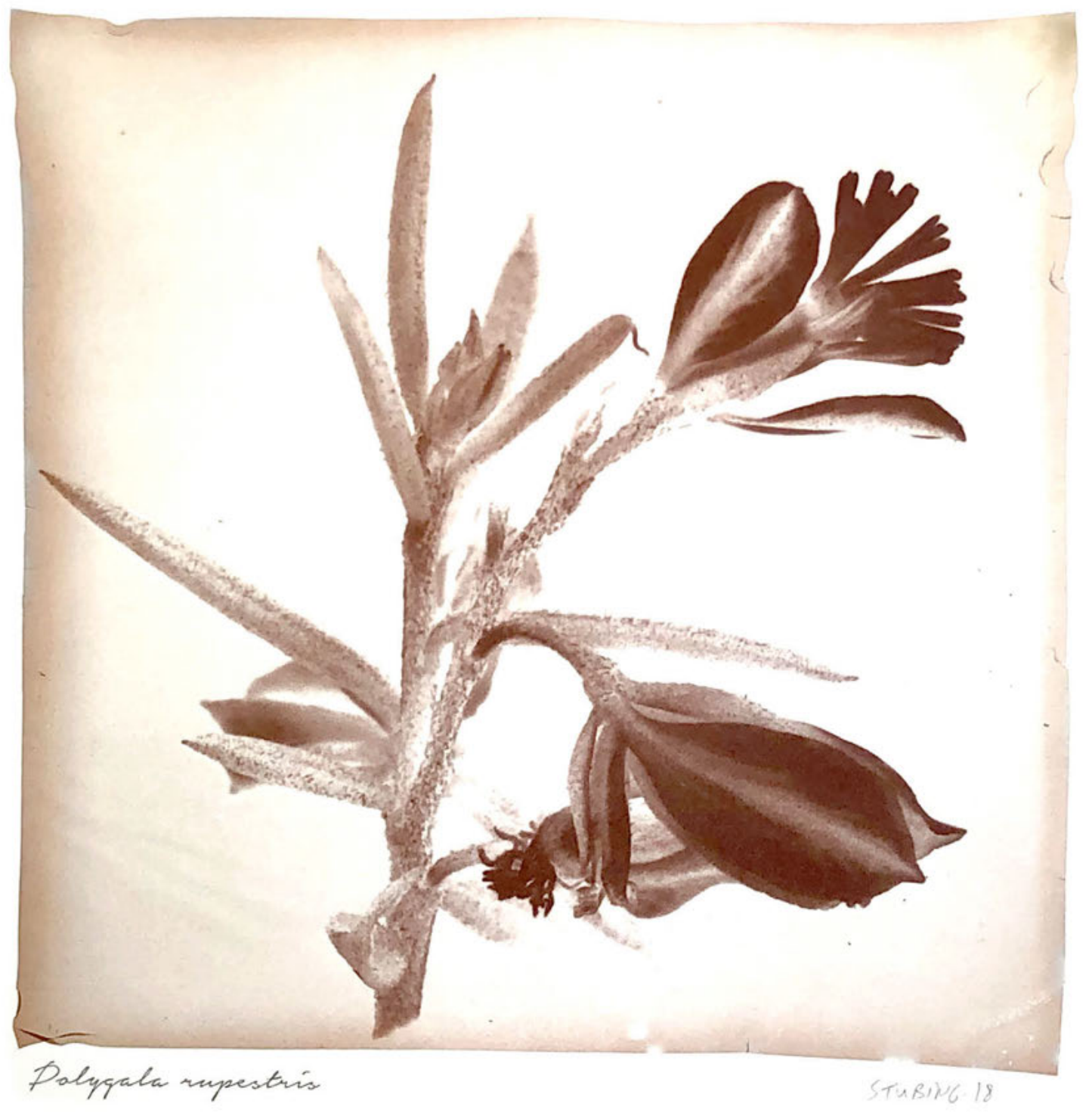




\section{Herba pedrera, Polígala de roca}

Oreja de rata, Polígala de roca

Polygala rupestris Pourr.

Poligalàcies

\section{Etimologia}

"Polygala": nom genèric derivat del grec i que significa molta llet, ja que es pensava que aquestes plantes servien per a augmentar la producció de llet en el bestiar.

"rupestris": epítet llatí que deriva de rupes, -is, que significa roca o penyal, i que s'aplica a les plantes que viuen sobre roques.

\section{Descripció, ecologia i distribució}

Xicoteta herba llenyosa en la base amb tiges de fins a $30-40$ cm, sovint prostrats, que posseeixen fulles curtes i allargades, una mica carnoses, de color verd fosc. La flors (de Maig a Juliol) són de color rosat, amb pètals dividits en el seu extrem, i envoltades de sèpals lanceolats amb aspecte d'ales. És una espècie pròpia de cingleres, penyes i runars, freqüent però sense formar grups densos, distribuint-se pel Mediterrani Occidental.

$<$ Herba pedrera

Argirotípia sobre gelatina transferida a paper.

$50 \times 50 \mathrm{~cm}$

Stübing 2018 


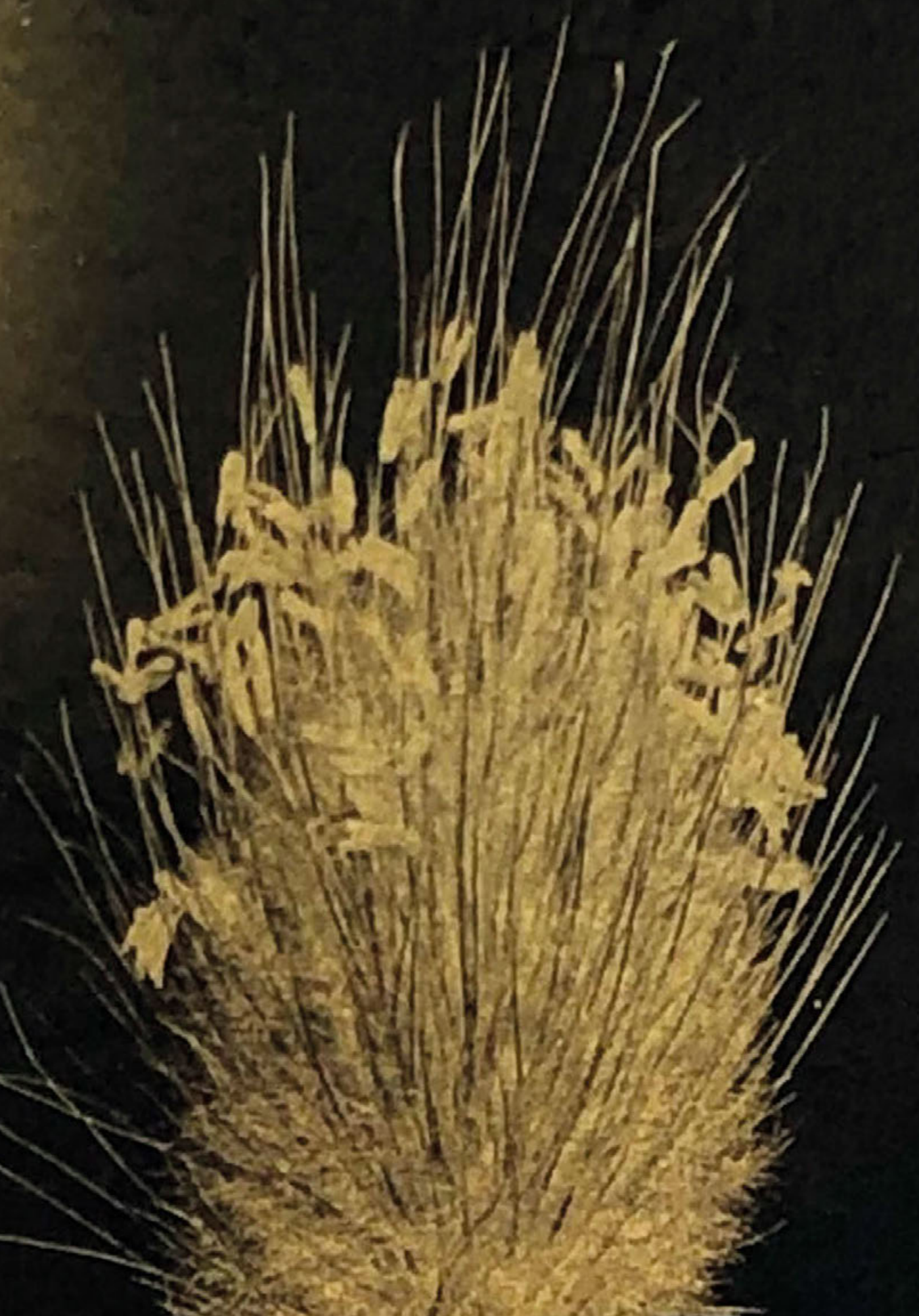




\section{PLATINOTÍPIES}

Tècnica antiga, patentada per William Willis en 1873, que es basa en l'aplicació d'una solució fotosensible sobre un suport, habitualment paper. Una vegada sec, es superposa un negatiu i se sotmet a la llum ultraviolada (sol o llums especials), de manera que a les zones exposades a ella, es fixa el platí (també s'utilitza el pal.ladi o una barreja de tots dos metalls nobles), adquirint un color negre de major o menor intensitat que es tradueix en una imatge monocroma, amb una extensa gamma tonal que va des del blanc fins al negre intens passant pels grisos.

Es considera que les imatges, de gran qualitat i riquesa tonal, així obtingudes són pràcticament indestructibles, podent perdurar milers d'anys, llevat del deteriorament del suport.

Aquesta tècnica va ser emprada per fotògrafs emblemàtics com Stieglitz, Cunningham, Steichen, Weston i altres. 


\section{Cua de llebra, Cua de cà, Moixos}

Lagrimas de la virgen, cola conejo

Lagurus ovatus L.

Gramínies

\section{Etimologia}

"Lagurus": Nom derivat del grec llacs (=llebre), i oura (=cua), referint-se a les forma de les espigues.

"ovatus": epiteto, del llatí ovatus, -a, -um (=ovado), referint-se a la forma de la panícula.

Descripció, ecologia i distribució

Gramínia anual de xicoteta talla, que sovint no supera els 20 cm, amb un o poques tiges acabades en una espiga ovalada (d'Abril a Juny), curta i densa, de tacte suau i plomós, amb aspecte que recorda a la cua d'un conill. Freqüent en herbassars de zones alterades i en les dunes litorals. Està present en tota la conca Mediterrània. 


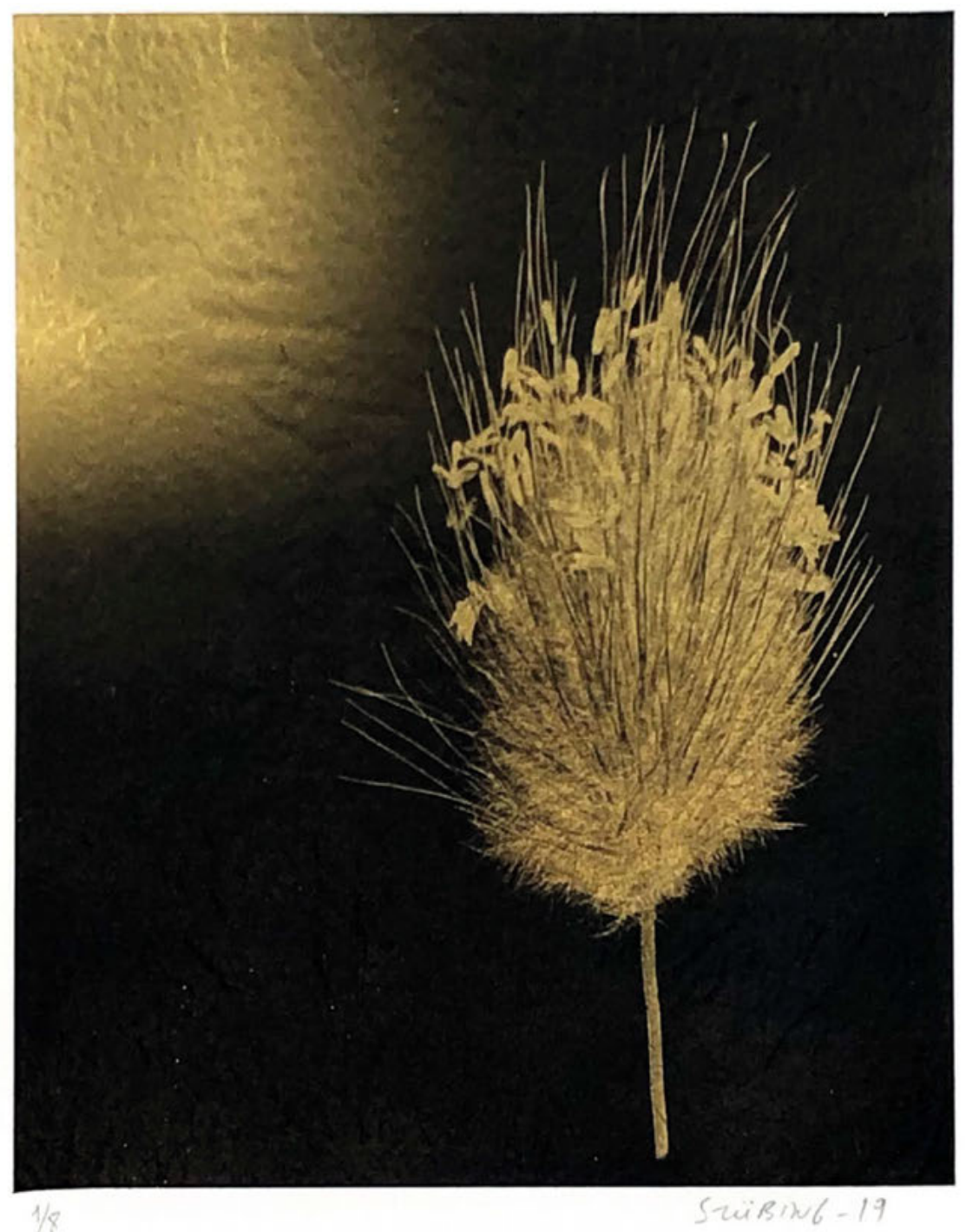




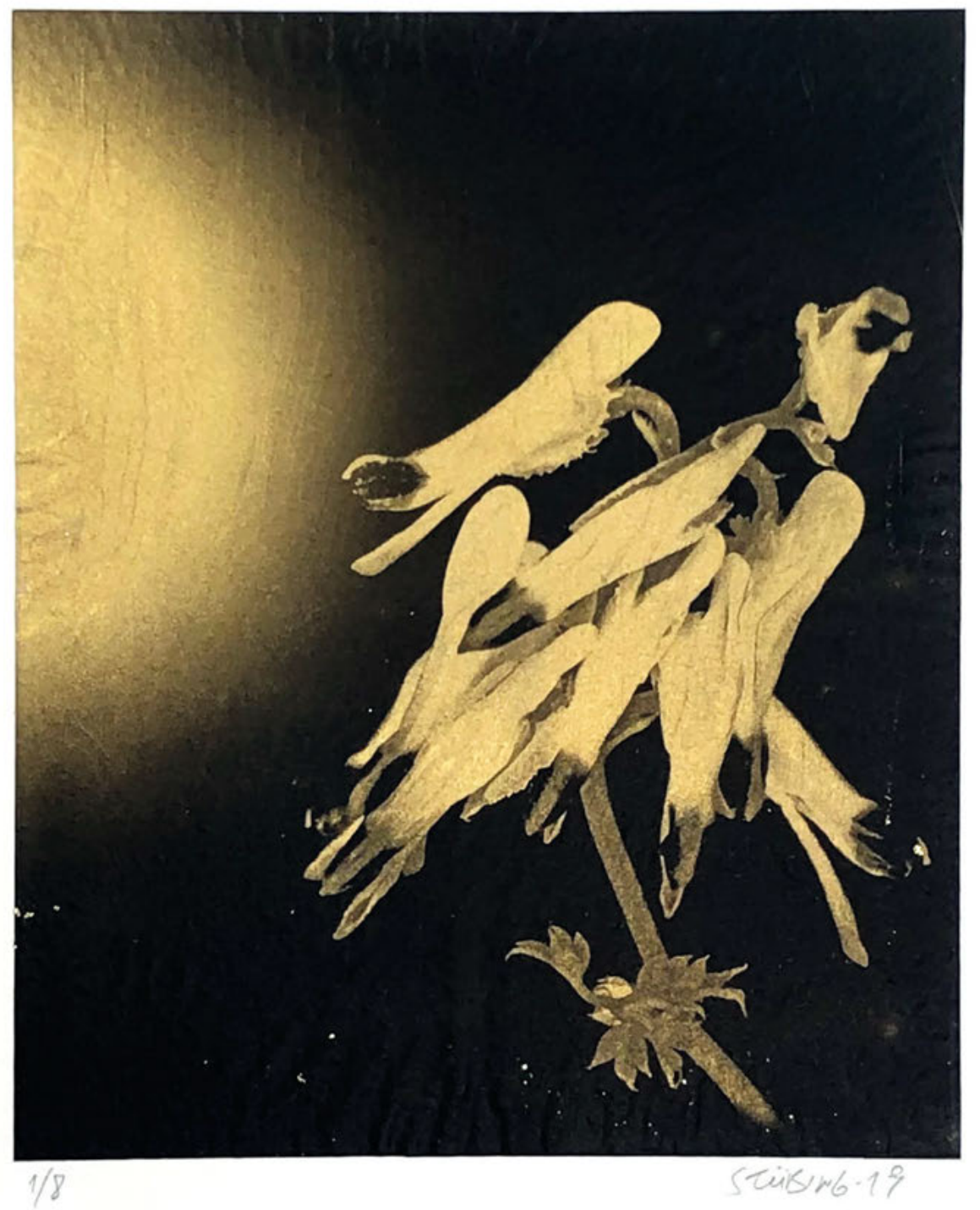




\section{Mataconill, Gallerets}

Palomillas, Sangre de Cristo

Fumaria capreolata L.

Papaveràcies

\section{Etimologia}

"Fumaria": nom genèric del llatí, fumus (=fum), possiblement pel color translúcid dels seus pètals florals, amb aparença de fum. "capreolata": epítet llatí, que significa "que té circells".

\section{Descripció, ecologia i distribució}

Herba de fulles dividides, sovint verd-blavoses, amb tiges que acaben en grups estrets de flors blanques (de Gener a Juny) amb aspecte de sac allargat, amb una marcada línia de color rosat intens o vermellós. És freqüent en cultius de regadiu, cunetes o entorns urbans, distribuint-se per la Medite-rrània Occidental. Tot i el seu aspecte pertany a la mateixa família que les roselles -gènere Papaver-.

\section{Usos}

Les seues summitats florides es van utilitzar popularment en infusos per estimular la secreció biliar i com antiespasmòdiques digestives.

\section{$<$ Mataconill}

Platinotípia sobre paper vellum i pa d'or

$50 \times 40 \mathrm{~cm}$

Stübing 2019 


\section{Card d'ase, Bufassa}

Cardo borriquero, Ansarina

Onopordum acanthium L.

Asteràcies

\section{Etimologia}

"Onopordon": nom llatí, que procedeix al seu torn del grec, de ono (ruc) i pordon (pet) o siga, pet de ruc, pels gasos intestinals que semblen provocar als ases quan mengen la planta.

\section{Descripció, ecologia i distribució}

Card de gran grandària, que pot assolir 1,5 m de talla. Les fulles, espinoses i de color verd a grisenc, formen una gran roseta de la qual naixen les tiges, amb abundants espines, igual que els capítols, amb flors de color rosat intens (de Juny a Setembre). Apareix en vores de camins i guarets, sent estrany a la comarca, ja que és espècie pròpia de climes més continentals "acanthium": epítet derivat del grec, que significa "espinós"

\section{Usos}

Les seues tiges tendres pelades, es preparen en ensalades campestres, a la manera d'espàrrecs. Els infusos de les summitats florides, en ús extern, s'han utilitzat popularment com antisèptiques i vulneràries en el tractament de disturbis cutanis (èczemes i dermatitis). 


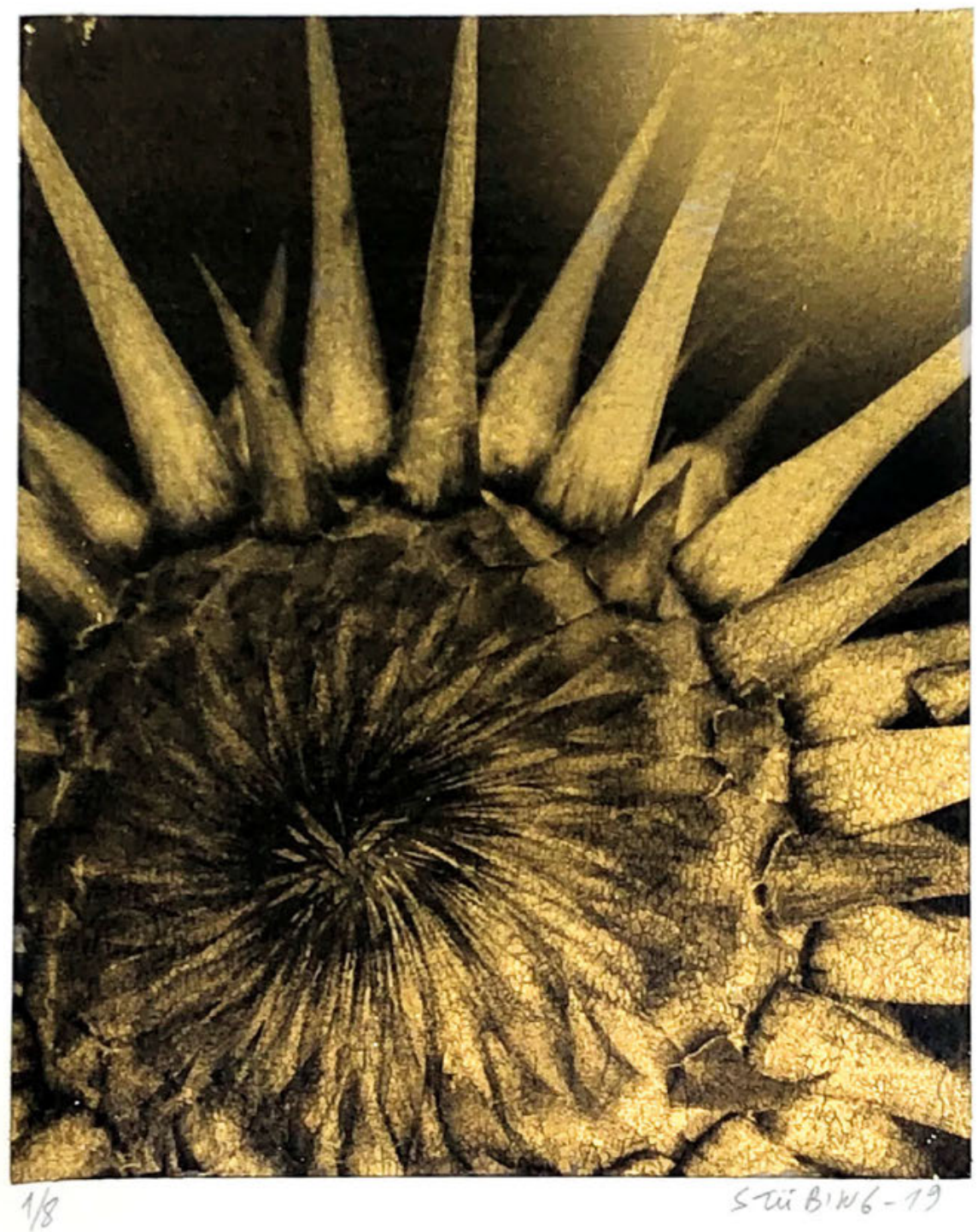




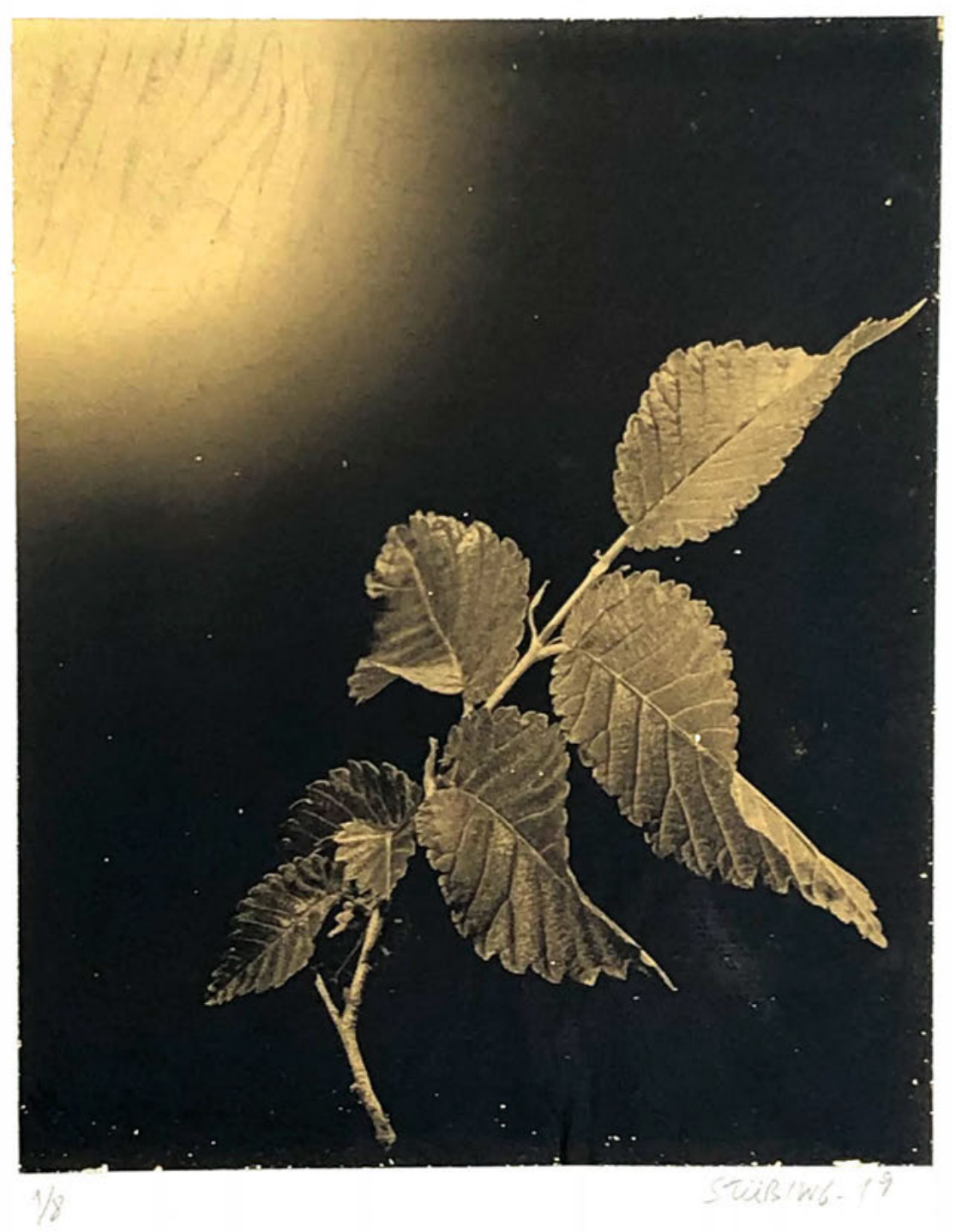




\section{Om}

Olmo

Ulmus minor Mill.

Ulmàcies

\section{Etimología}

"Ulmus": del llatí ulmus, nom donat per als oms.

"minor": epítet llatí que significa: menut, xicotet, menor.

\section{Descripció, ecologia i distribució}

Arbre caducifoli de gran talla, sovint superior a $10 \mathrm{~m}$, amb fulles de tacte una mica aspre i bord serrat. És propi de vores de rius i fonts, havent-se plantat també en tanques de regadiu, vores de camins, etc. Es distribueix per tota Euràsia, però es troba en forta regressió a causa de la grafiosi, una malaltia fúngica que ha reduit la majoria de les seues poblacions a xicotets arbustos rebrotadors.

\section{Usos}

L'escorça de les branques s'utilitza popularment en el tractament de diarrees i enteritis. El seu oleat es fa servir en dermatologia per al tractament d'èczemes, dermatosis escatoses i pruiija. D'algunes varietats s'extreia suro en quantitat menuda, format a les ales de les tiges.

$<$ Om

Platinotípia sobre paper vellum i pa d'or

$50 \times 40 \mathrm{~cm}$

Stübing 2019 


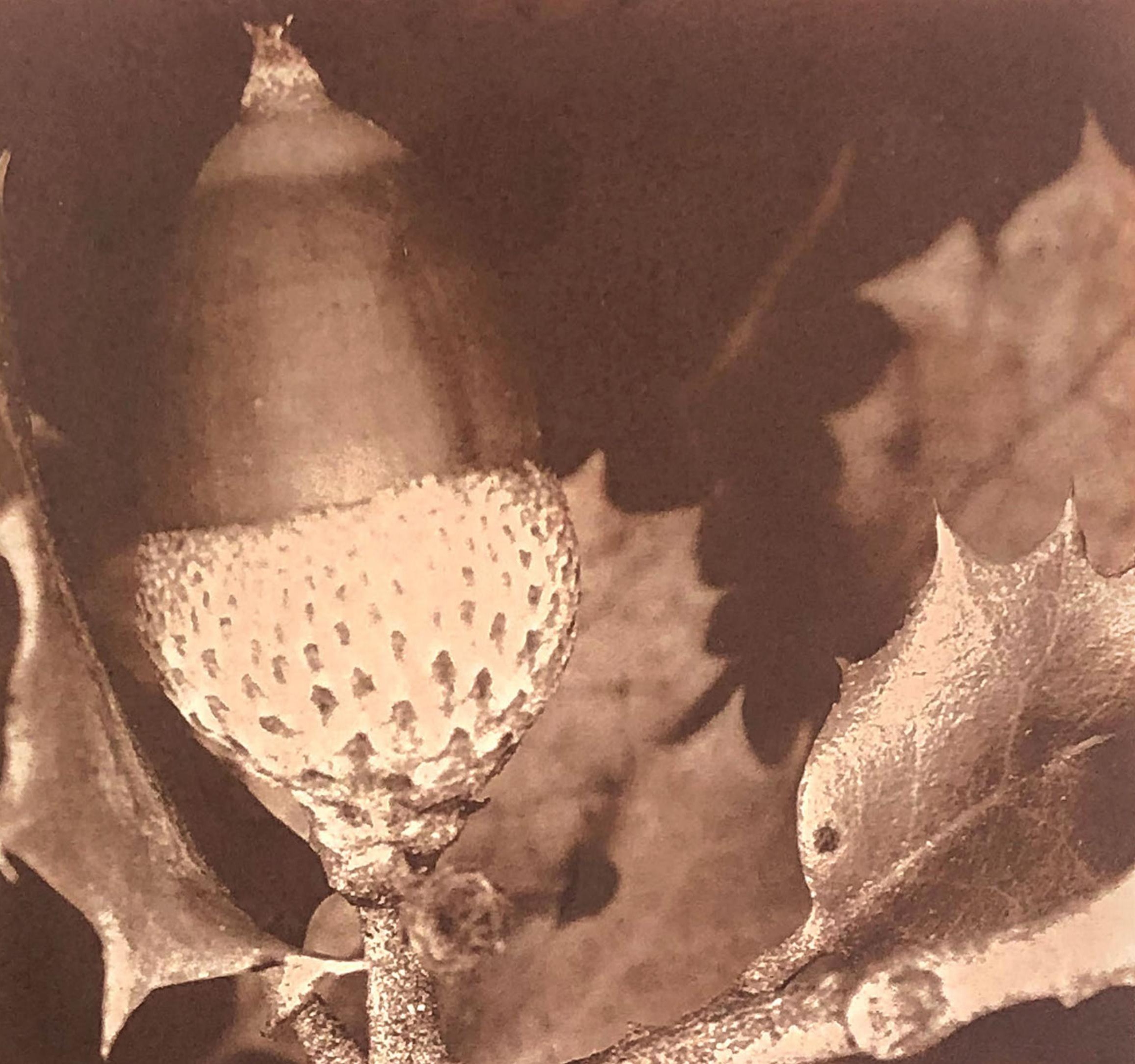




\section{M PRESSION S L U MÍNIQUES}

Són impressions en blanc i negre a les sals de plata sobre paper, obtingudes mitjançant processos experimentals diferents dels establerts per a les còpies convencionals.

Per a les impressions lumen o "lumen print", es disposen negatius o altres objectes més o menys opacs (fulles, plantes, etc.) Sobre paper fotogràfic fotosensible, per a la posterior exposició a l'acció de la llum durant un període més o menys prolongat, que excedeix amb molt al convencional. El resultat és una impressió, de resultats fins a cert punt incontrolables, de vegades amb colors cridaners $i$ inestables, que no es revela i que requereix ser fixada per a la seva conservació. Aquesta tècnica va ser desenvolupada pel fotògraf Jerry Burchfield (1947-2009), lluitador per la protecció de l'entorn i famós per les seues impressions lumen de la Flora de l'Amazones, realitzades "in situ".

Aquesta tècnica, a mig camí entre la fotografia i la pintura, va ser descoberta per Pierre Codier el 1956 i emprada per artistes com Paul Klee, Max Ernst $i$ Antoni Tàpies, entre d'altres. 


\section{Cossiada, Cap de frare, Coroneta de frare}

Cebollada, cogullada

Globularia alypum L.

Globulariàcies

\section{Etimologia}

"Globularia": nom llatí al·lusiu a la forma globosa dels seus capítols florals. "alypum": epítet del llatí alypon (=sense dolor), a causa de l'efecte purgant suau que posseeix.

Descripció, ecologia i distribució

Arbust perennifoli de base llenyosa i abundants tiges paral-lels, rarament superior a $60 \mathrm{~cm}$. Les fulles són verd-blavoses, rígides i agudes, i les tiges acaben en capítols de flors de color blau intens (de Novembre a Abril). Sovint les flors perifèriques formen un vistós anell, que justifica el seu nom popular de 'coroneta de frare'. És freqüent en matollars serials secs i assolellats de la majoria de països que circumden la Mediterrània.

\section{Usos}

Els fulls s'han utilitzat per la seva acció purgant, per alleujar el restrenyiment, encara que actualment està en desús. 


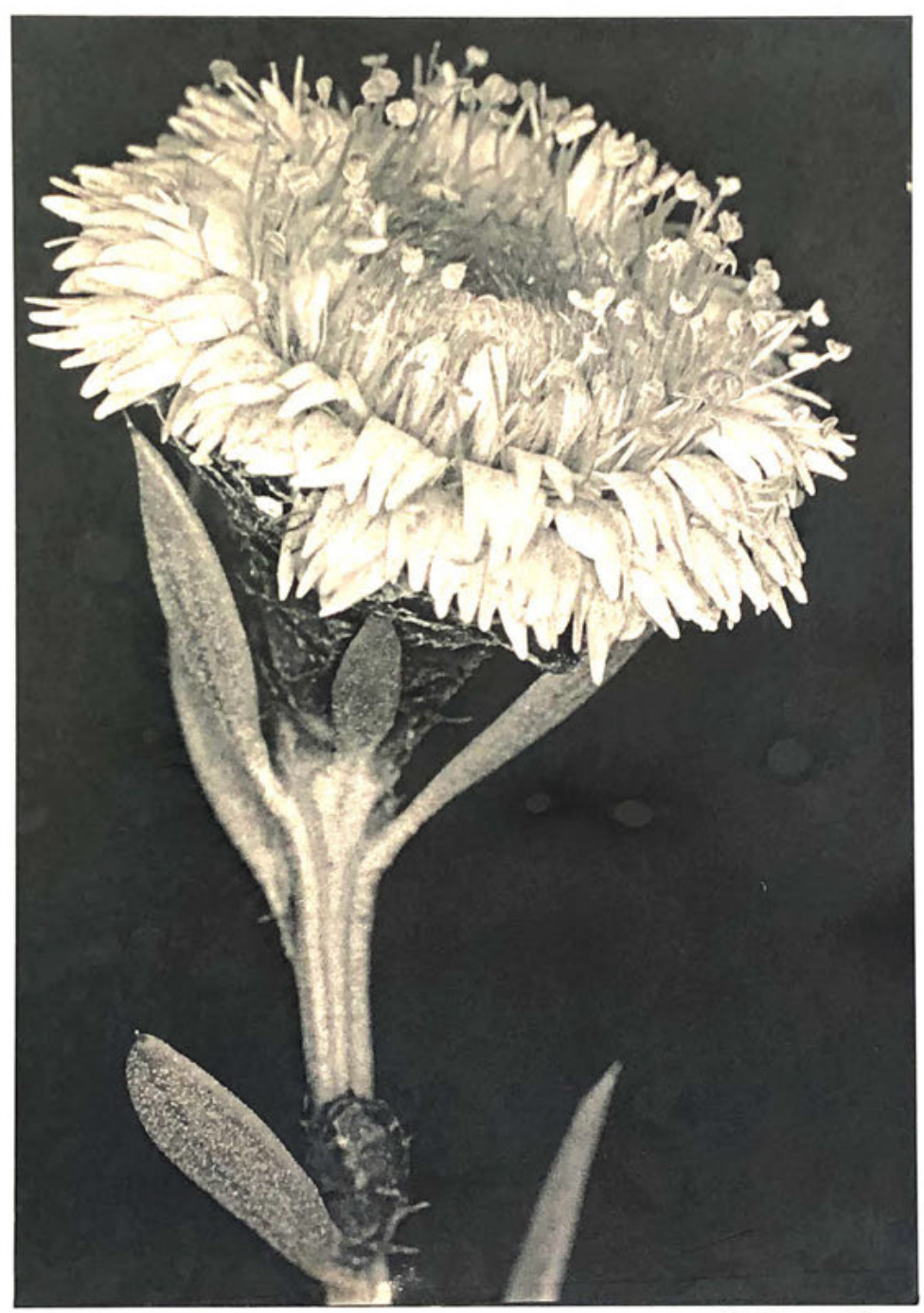

Qlabularia alspum 


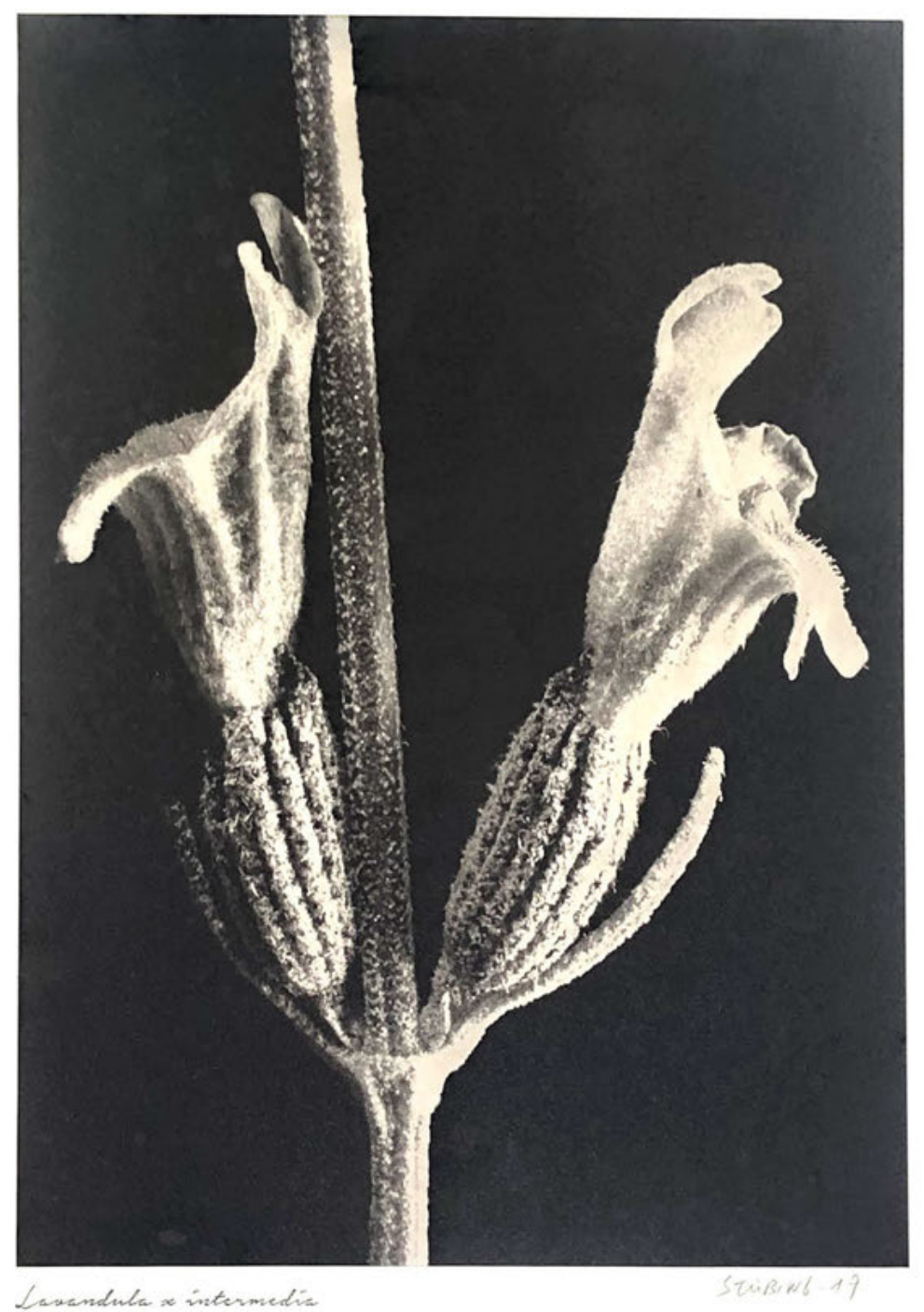




\section{Lavandí}

Lavandín, Lavanda hibrida

Lavandula $\times$ intermedia Emeric

Labiades

\section{Etimologia}

"Lavandula": Nom de l'italià lavanda o del francés lavande, probablement síncopes del llatí medieval lavandula, d'origen incert, que es donava a les plantes que servien per a perfumar l'aigua.

"intermedia": epítet del llatí "intermedius", de caràcter intermedi.

\section{Descripció, ecologia i distribució}

Arbust aromàtic de fins a $80 \mathrm{~cm}$ d'altura, resultant de la hibridació natural entre la lavanda (Lavandula angustifolia Mill.) i l'espígol (L. latifolia Medik.) o, més fàcilment, de l'asilvestrament dels híbrids de tots dos progenitors obtinguts artificialment, cultivats per a l'obtenció d'essències o com a plantes ornamentals. L'espècie parental més freqüent a la comarca és l'espígol, freqüent en matollars oberts i pinedes.

\section{Usos}

S'utilitzen les seues summitats florides, sotmeses a destil|lació per corrent de vapor, amb la finalitat d'obtindre l'oli essencial de lavandí, base en la industría de perfums per a fer l'aigua de lavanda, i com a corrector organolèptic de productes destinats per a l'endreça corporal.

\section{$<$ Lavandí}

Impressió luminica a les sals de plata, virat a l'or i seleni

$70 \times 50 \mathrm{~cm}$

Stübing 2018019 


\section{Carrasca}

Carrasca, Encina

Quercus rotundifolia Lam.

Fagàcies

\section{Etimologia}

"Quercus": nom llatí per a designar els arbres o arbustos productors de bellotes.

"rotundifolia": epítet llatí, per a plantes de fulla arredonida.

\section{Descripció, ecologia i distribució}

Arbre perennifoli que localment no sol superar els 5 o 6 m. d'altura, excepte en exemplars monumentals. Les fulles són ovalades o arredonides, de vora espinosa en els rebrots basals i exemplars joves, sense elles en les de la copa. El fruit, la bellota, és comestible. És l'arbre que dominava en el paisatge valencià i les seues formacions constituien el bosc madur i potencial del territori, fins que la desforestació (tala, incendis, degradació de sòls) I'ha arraconat a llocs poc accessibles o reduït a bosquets menuts; la muntanya poblada de carrasques adultes, es diu carrascal o carrascar, i el de carrasques joves xaparral.

\section{Usos}

S'utilitza popularment l'escorça del tronc i branques velles, per les seues propietats astringent-antidiarreiques, en el tractament de diarrees.

\section{Carrasca}




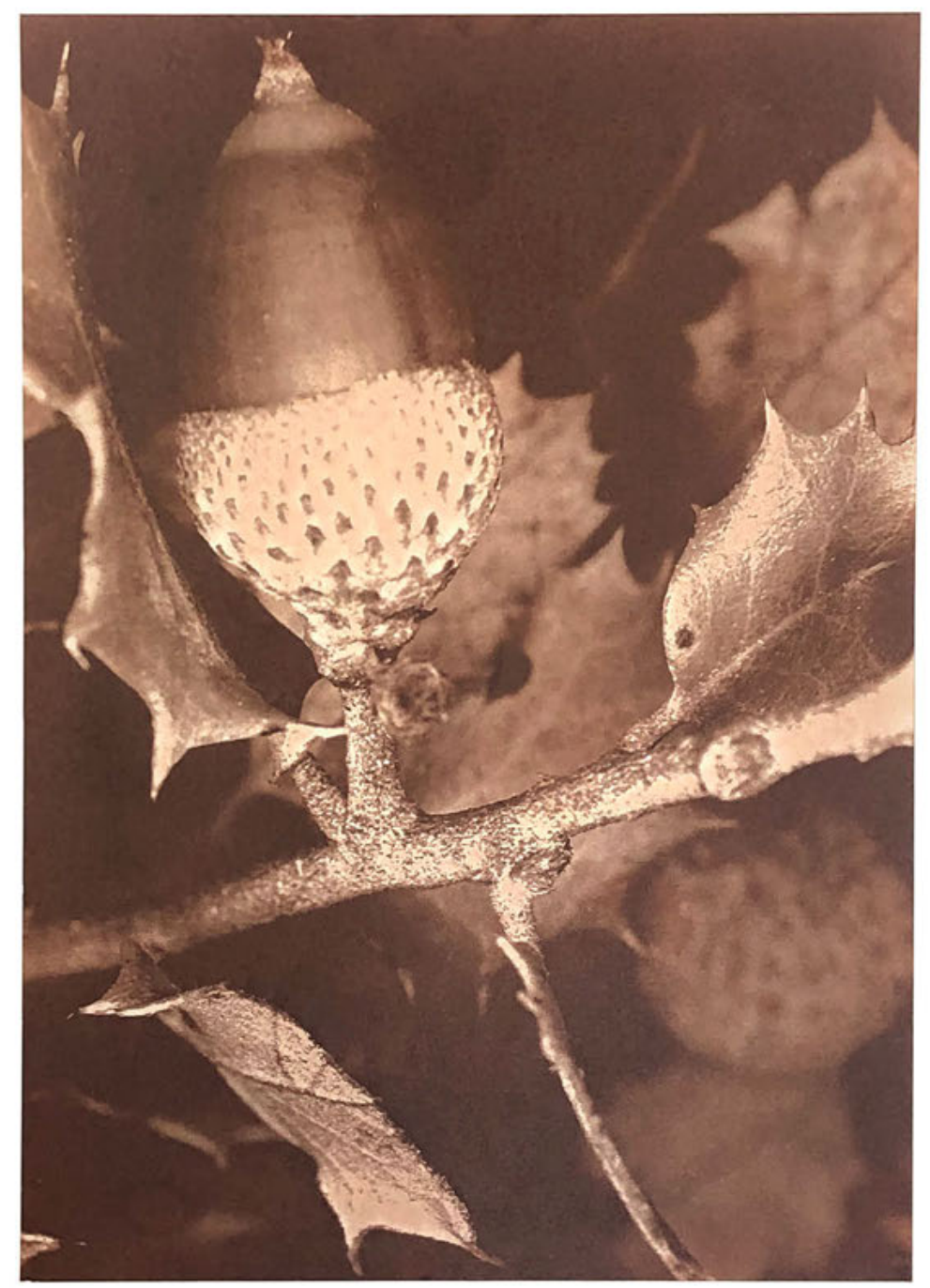

Qmerens raturdifalia

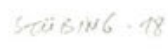




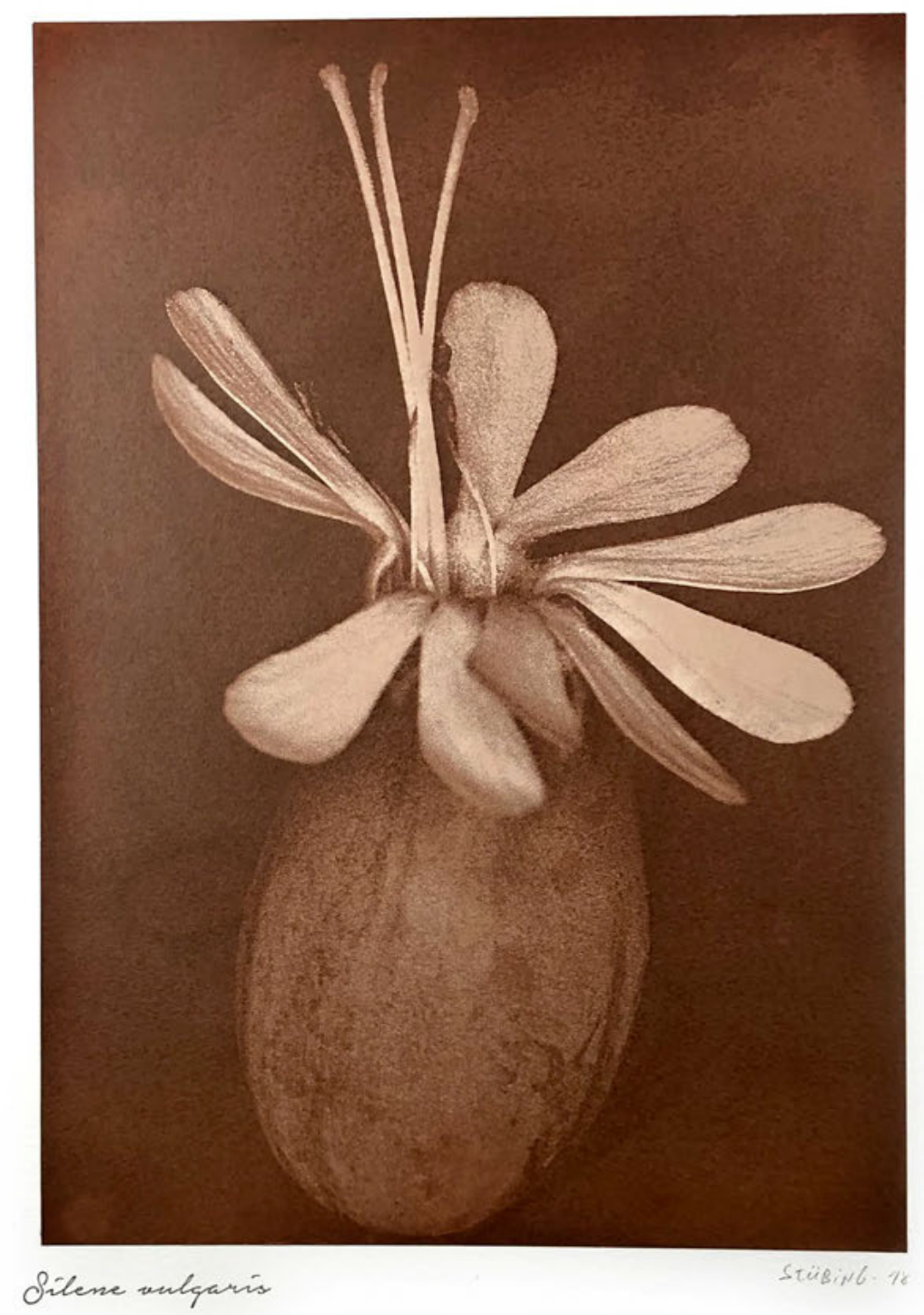




\section{Esclafidors, Petets, Conillets fins, Colitxos}

Collejas, Farolillos, Berzuela

Silene vulgaris (Moench.) Garcke subsp. vulgaris

Cariofilácies

\section{Etimologia}

"Silene": nom genèric al·lusiu al personatge de Sileno -sempre representat amb el ventre unflat-, pare adoptiu de Dionisos.

"vulgaris": epítet llatí, que significa comú.

\section{Descripció, ecologia i distribució}

Planta rizomatosa erecta o ascendent, amb tiges i fulles allargades de color verd blavenc. Flors (de Maig a Juliol) penjants, amb el calze globós i unflat. Habita en fenalars i altres herbassars, així com als guarets i camps de cultiu. Espècie d'ampla distribució a les zones templades d'Euràsia i regions properes.

\section{Usos}

Les fulles joves i tendres es consumeixen com a verdura, preparant amb elles truites o ous remenats. Amb els poncells joves de roselles es fan servir per a fer gaspatxos valencians. En l'època de Quaresma les seues fulles es fiquen a les olletes de cigrons. L'infús de les seues fulles, riques en sals potàssiques, es pren com a diürètic.

$<$ Esclafidors

Impressió luminica a les sals de plata, virat a l'or i seleni

$70 \times 50 \mathrm{~cm}$

Stübing 2018019 


\section{Jonça de matollar}

Lastoncillo

Carex halleriana Vill. Asso

Ciperàcies

\section{Etimologia}

"Carex": del grec Kairo, que significa fer mal, en relació al marge tallant de les fulles.

"halleriana": epiteto específic dedicat al metge i botànic suís Albrecht von Haller (1708-1777).

Descripció, ecologia i distribució

Petita herba perenne que forma mates denses, amb totes les fulles planes, rígides i amb vores aspres, naixent de la base i de color verd fosc. Tiges de secció triangular amb les vores també aspres. Flors poc aparents (de Març a Juny). És freqüent formant part de pastures permanents seques, en clarianes de matolls i boscos dels països riberencs de la Mediterrània. 


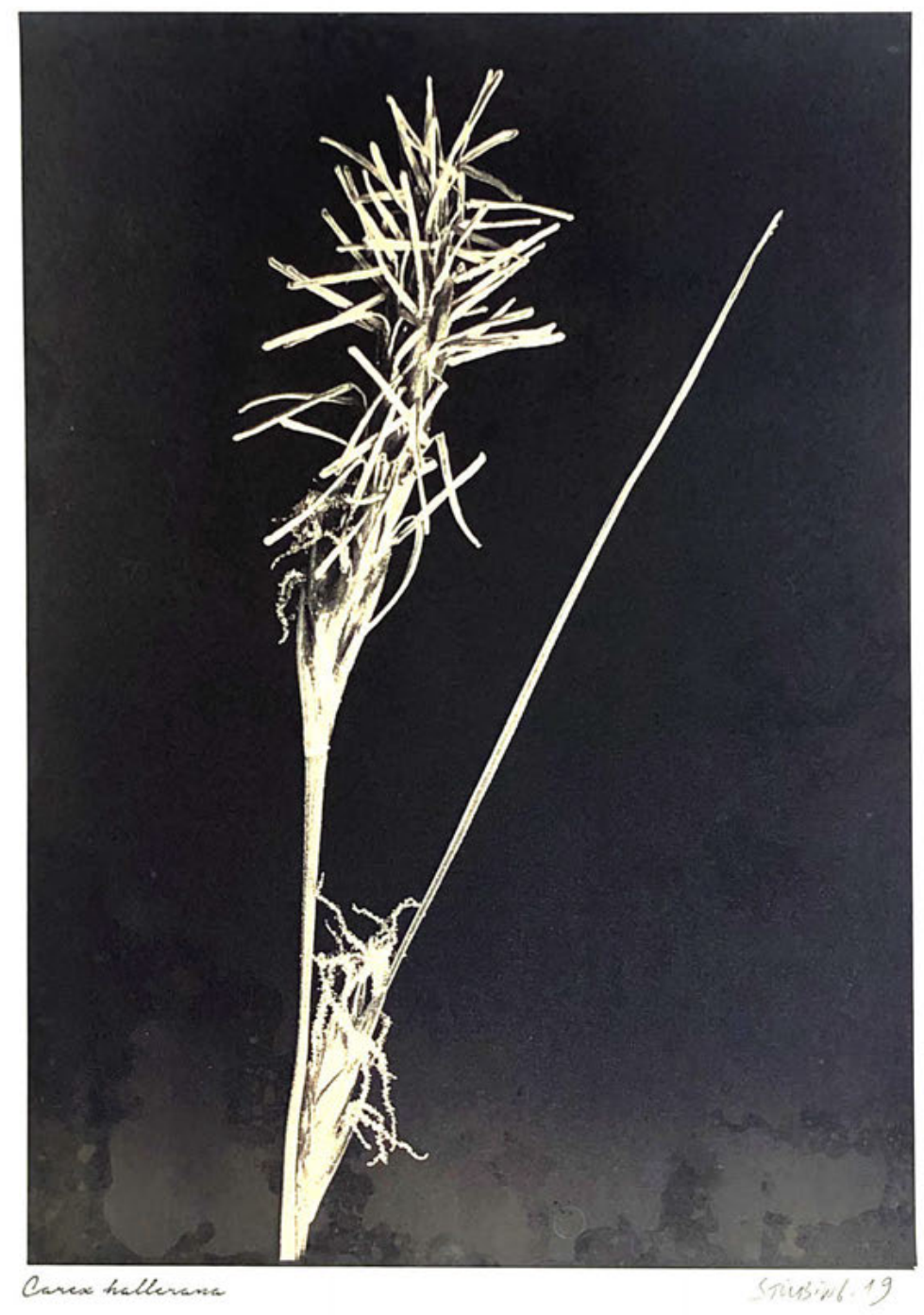




\section{$M A \mid G 2050$}

El Dia Internacional de la Diversitat Biològica se celebra el 22 de maig de cada any per decisió de l'Assemblea General de les Nacions Unides del 20 de desembre de 2000, en la Resolució 55/201.

El concepte de diversitat biològica es refereix al conjunt d'espècies, ecosistemes i recursos genètics existents en el planeta. La seua conservació és fonamental, no solament per al funcionament d'aquest, sinó també com a font d'informació científica per a entendre l'evolució i com a font d'aliments $i$ medicines.

Segons l'ONU cada dia desapareixen, conseqüència fonamentalment de les activitats humanes (canvi climàtic, desenvolupament insostenible, explotació de recursos, urbanisme incontrolat, etc..), entre 100 i 300 espècies de plantes, animals i microorganismes, de tal manera que s'estima que llevat que canviem el nostre comportament a nivell global, una quarta part de les espècies actuals s'extingiran al llarg dels pròxims 20 a 30 anys.

És possible, que almenys quatre de les espècies representades, com a conseqüència fonamentalment del canvi climàtic, puguen desaparéixer en els pròxims 30 anys, encara que sorprén el fet que porten en el planeta més de 100 milions d'anys enfront dels poc més de 300.000 anys d'existència que té l'espècie humana. 


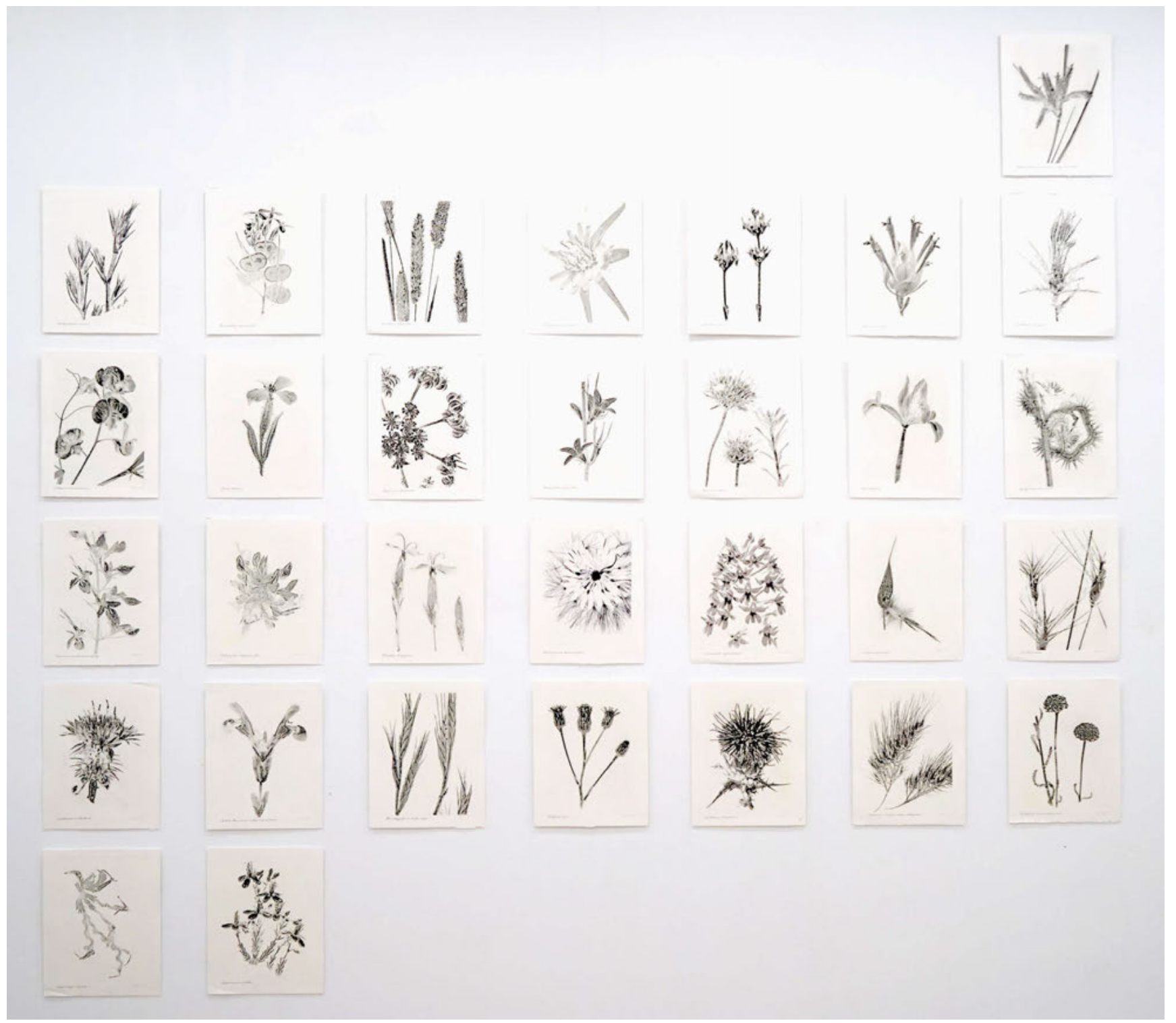

Maig 2050

Tinta y acrilic sobre paper Arches 88

Políptic aprox. 4 × 5 m (31 peces, 50 × 40 cm)

Stübing 2017/18 

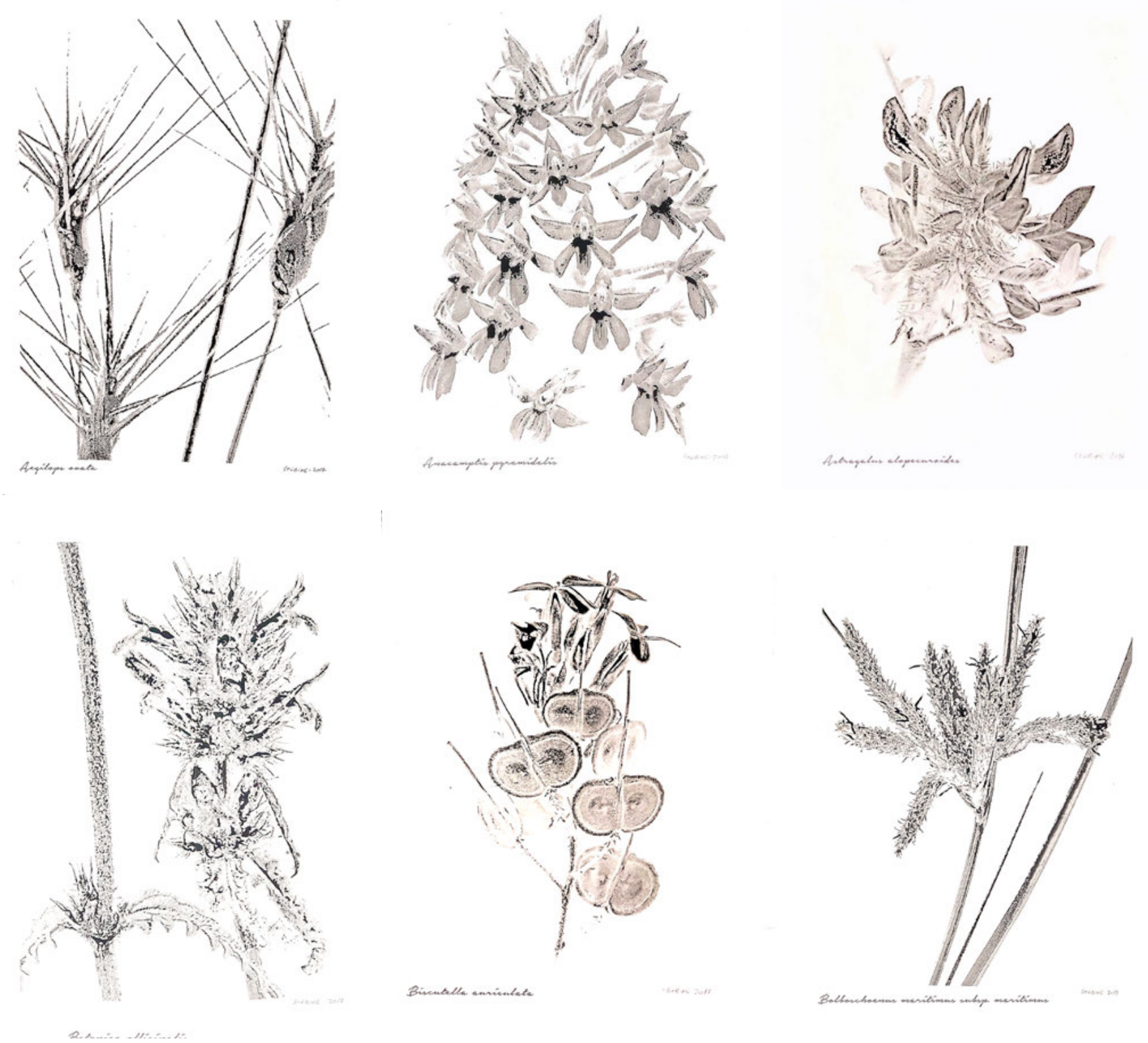

Maig 2050 (Detalls)

6 peces, $50 \times 40 \mathrm{~cm}$

Stübing 2017/18 

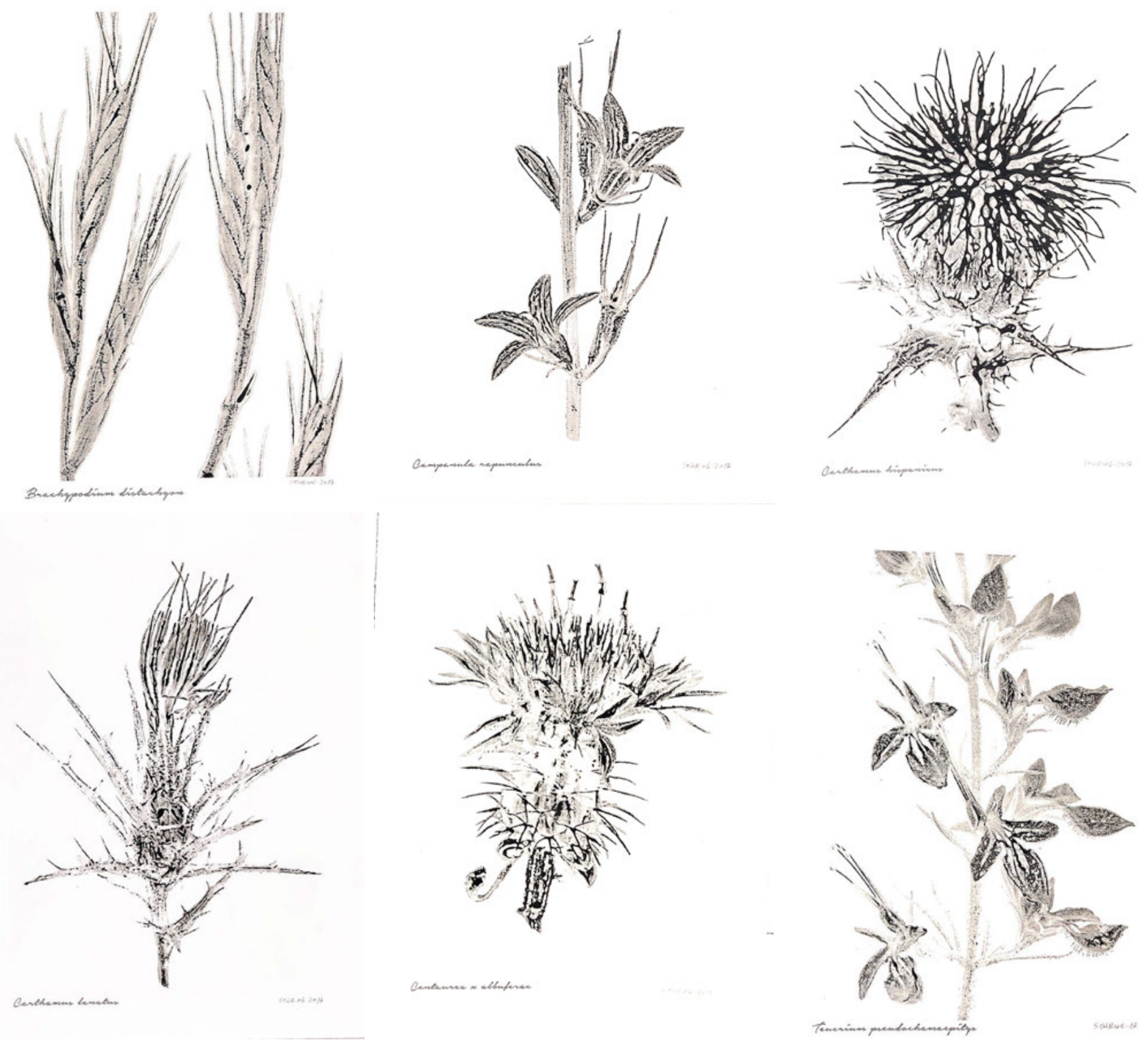

Maig 2050 (Detalls)

6 peces, $50 \times 40 \mathrm{~cm}$

Stübing 2017/18 


$$
\begin{aligned}
& \text { Yot }
\end{aligned}
$$

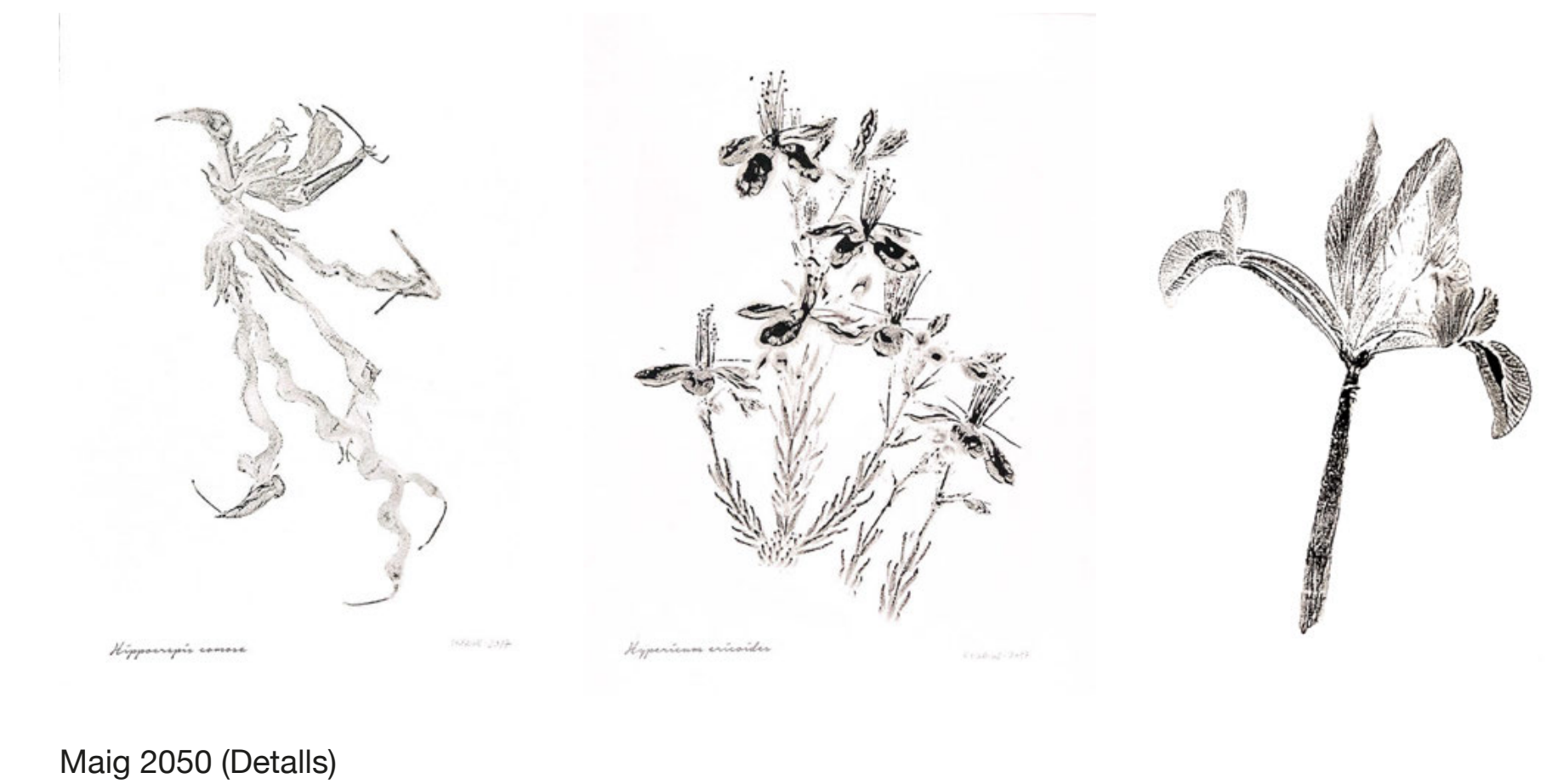



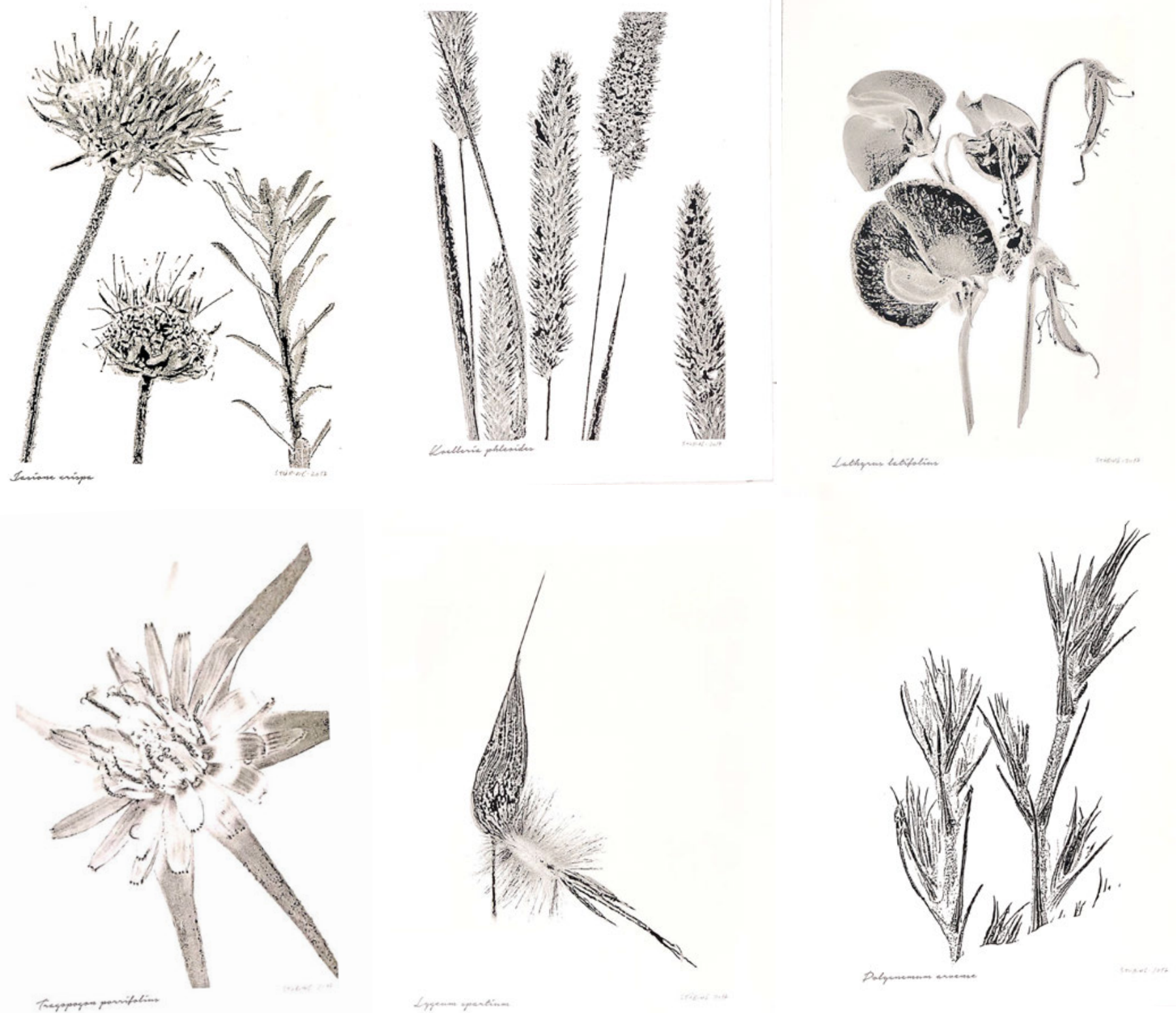

Maig 2050 (Detalls)

6 peces, $50 \times 40 \mathrm{~cm}$

Stübing 2017/18 

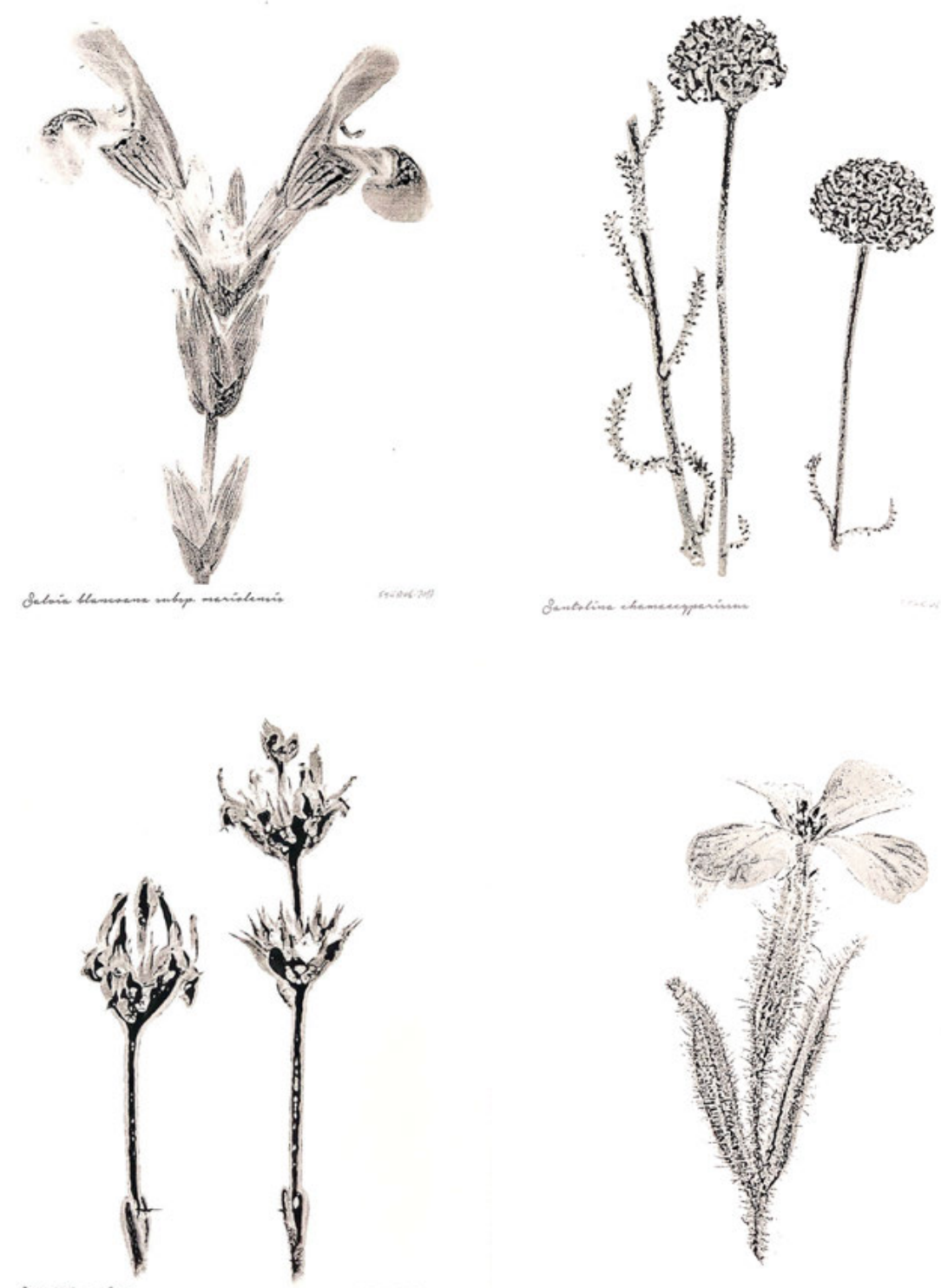

gitene dictions
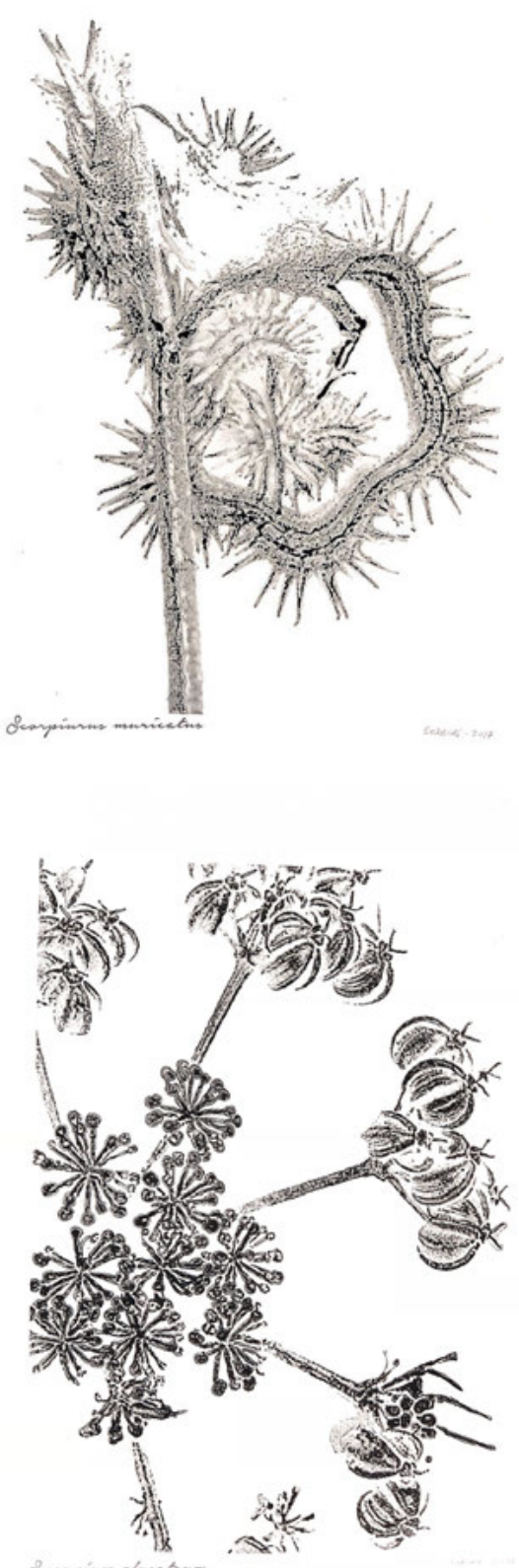

Maig 2050 (Detalls)

6 peces, $50 \times 40 \mathrm{~cm}$

Stübing 2017/18 
B I O GR A Fí A / S TATEM E N T 


\section{Biografia}

Gerardo *Stübing (*Stübing), nascut a València (1957). Professor de Botànica de la Universitat de València. Graduat en Belles arts, actualment realitza la seua tesi *dioctoral en producció artística en la Universitat Politècnica de València.

Artista valencià d'origen alemany que compta amb una dilatada trajectòria i reconeixement científic en el camp de la Botànica (professor universitari durant 30 anys en la Universitat de València). Des de fa 15 anys desenvolupa simultàniament un treball de creació artística.

Les seues obres han sigut seleccionats en més de 60 concursos, alguns d'ells al més alt nivell com el premi BMW, havent obtingut diversos premis i reconeixements. Nombroses exposicions tant col·lectives (més de 60) com a individuals (10).

Treballs en institucions oficials: Universitat de València, Jardí Botànic de Madrid, Universitat Internacional d'Andalusia, Centre d'Estudis del Jiloca, Ajuntament d'Alfafar, Fundació Bancaixa de Segorbe, Institut Britànic de Sevilla i Ministeri d'Agricultura

\section{Statement}

L'objectiu de les meues obres, més enllà de l'estricta creació artística, és aprofundir en la consciència de la bellesa i harmonia de la naturalesa i experimentar una producció artística basada en ella, buscant sensibilitzar l'observador en l'estima i respecte pel nostre entorn natural, protegim allò que volem, però per a voler quelcom o a algú prèviament hem de conéixer-ho. Establisc una hibridació alquímica entre ciència, art i naturalesa, combinant tècniques fo- 
togràfiques dels segles XIX, XX i XXI per a desenrotllar obres que poden ser considerades, ja siga com a abstraccions ambigües de la realitat, o com a representacions figuratives d'aspectes inusuals d'espècies botàniques.

\section{Assoliments recents (2018/21)}

\section{8}

-O0 Biennal de l'Havana (maig de 2018) amb la instal·lació "Ecosistemes cubans".

-Exposició en solitari "320 nm", Galeria Tapinerate (València). Juny de 2018.

-Exposició grup ARO: "El Futur". Obra social *Caixa Ontinyent. Desembre 1018-Gener 2019, amb la instal.lació "Maig 2050".

-Seleccionat Revista The HAND, números 21 i 23.

\section{9}

-Seleccionat X Biennal d'*Art *Riudebitlles (Barcelona).

-Seleccionat en el llibre: Anderson, Christina Z. *Cianotype: T he Blueprint en la pràctica contemporània. Nova York: Focal Press, 2019, 320 pàgines.

-Seleccionat Revista The HAND, números 24, 25 i 26. -Seleccionat en les exposicions de Smith Gallery (Johnson City, Texas), "black / white" (curadora Jennifer Schlesinger) i "Art + "Science" (curadora Linda Alterwitz).

-Seleccionat desena exposició online anual d'art "Abstracts" 2019. Light Space \& Time.

-Seleccionat Art Intersection Light Sensitive 2019 (Gillbert, Arizona), curador Christopher James. Març de 2019.

-Seleccionat The Art Center, Alternative perspective exhibition (Dover). 
-Esment d'honor de L.A. *Photo *Curator's "*Trees" (curadora Dulce Stein).

-Seleccionat Galeria Las Laguna, "Captured". (Laguna *Beach, CA). -Seleccionat Biennal Ciutat Vella Oberta 2019. Polyptico BotaniKa.

València.

-Exposició Grup Arteenred: Leonardo da Vinci, de l'observació a la pràctica. Alacuas, 2019/20.

\section{0}

-Seleccionat Revista The *HAND Magazine, número 28.

-Art Karlsruhe. Galeria Javier Román (Màlaga).

-Seleccionat en "*Then *and *Now 2, Photographic competion". National Museum Gdansk (*Poland) 2020.

-Seleccionat Biennal Olot Fotografia (Olot, Spain).

-Seleccionat Better Living Throught Chemistry, Fraction Magazine.

-Exposició "Joies botaniques de la Ribera", Sumacarcél, en

col·laboració amb la Mancomunitat de la Ribera i la Universitat de

València.

-Seleccionat Exposició Revista The HAND Magazine in Through

This Lens Gallery exhibition. Durham, NC.

-Best Sèries. NY Photo Curator, Theme: "Connection". *Curated by

Adam Finkelston.

-Alternative *Photography Award, Society of Arts and Crafts (SAC's) \& Stonehenge Gallery: The 2020 Photo Competition. Montgomery, $A L$.

-Seleccionat Instant Imagery exhibition at the ES Center for Photography (Greenville, SC), juried by Michael Itkoff.

-Seleccionat Fantastic Film Show at LightBox Photographic Gallery (Astoria, OR), juried by Michael Kirchoff of Analog Forever Magazine. - Winner Portfolio Fine Art category, *Moscow *International Foto Awards 2020.

-Climatic change sèries, publicación digital en Dodho Magazine. 
-Seleccionat "Irreplaceable sources". Joey *Aromhalt from "Lose the Film".

-Seleccionat David Orton *Gallery 6th Annual Group Show en línia, juried by Paula Tognarelli, Executive Director and Curator of *the Griffin Museum of Photography (Winchester, DT.).

-Denis Rousssel Award 2020. Outstanding Work for "Climatic change" sèries, (Rfotofolio *Selection) jurat Christopher James.

-Seleccionat Altered *Reality International Exhibit. LightBox Photographic Gallery (Astoria, OR). Jurat: Diana H. Bloomfield, Karen Hymer, Jim Fitzgerald.

-Seleccionat XXXIII Certamen Fotografia José Antonio Sequi. Tarancón (Conca).

- ${ }^{\star}$ Selecccionado XIX Premi Fotografia Universitat de Múrcia (Múrcia).

\section{1}

-Seleccionat "self". Joey Aromhalt from "Lose *the Film".

-Seleccionat Analog Forever's online *group exhibition "A Certain Kind of Blue".

-Seleccionat "Your Daily *Photograph", *Guest Curator Adam

Finkelstone.

-Seleccionat "^Your *Daily *Photograph", Guest Curator Diana Bloomfield.

-Seleccionat The HAND Magazine número 29.

-Seleccionat "Visions *of Nature" at Light Art Space in Silver ciity, New Mexico. Curator Diana Bloomfield.

-Seleccionat XX Premi Fotografia Universitat de Múrcia (Múrcia). -Bronze in *Portfolio Fine Art *category, Moscow International Foto Awards 2020. 


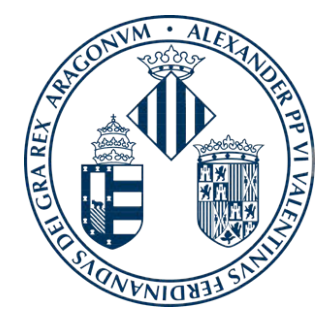

Col•labora:

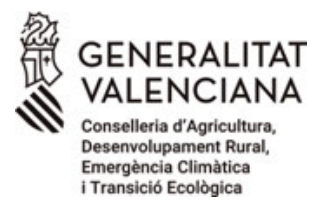

AJUNTAMENT

DE

SUMACÀRCER

\section{Universitat + Territori

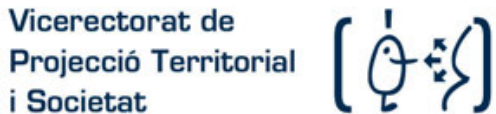 \\ i Societat}

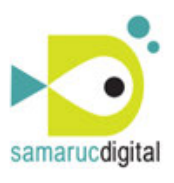

